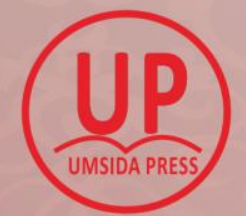

UMSIDA PRESS

JI. Mojopahit 666 B Sidoarjo

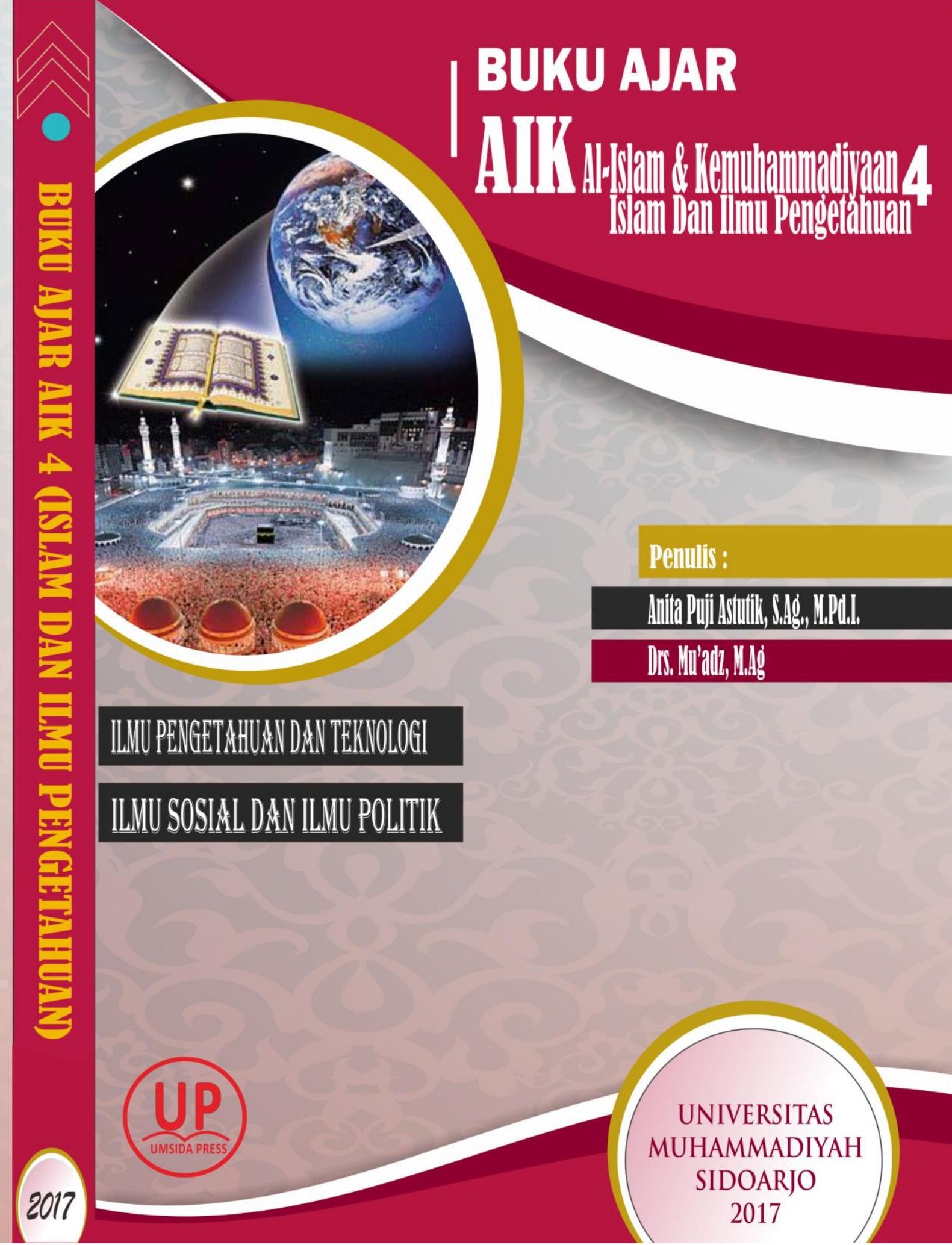




\title{
BUKU AJAR \\ AL-ISLAM DAN KEMUHAMMADIYAHAN - 4 \\ (AIK - 4)
}

\author{
Penulis \\ Anita Puji Astutik, S.Ag., M.Pd.I. \\ Drs. Mu'adz, M.Ag
}

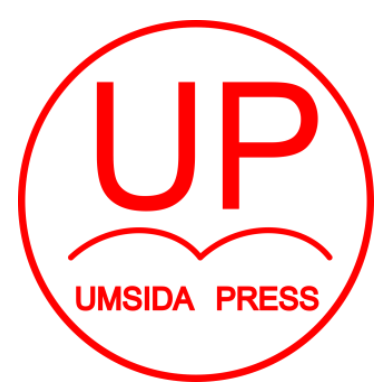

Diterbitkan oleh

UMSIDA PRESS

J1. Mojopahit 666 B Sidoarjo

ISBN: 978-979-3401-78-2

Copyright@2017.

Authors

All rights reserved 
BUKU AJAR AL-ISLAM DAN KEMUHAMMADIYAHAN 4 (AIK - 4)

\section{Penulis :}

Anita Puji Astutik, S.Ag., M.Pd.I.

Drs. Mu'adz, M.Ag

\section{ISBN :}

978-979-3401-78-2

\section{Editor :}

Puspita Handayani, S.Ag., M.Pd.I

M. Tanzil Multazam, S.H., M.Kn.

\section{Copy Editor :}

Fika Megawati, S.Pd., M.Pd.

Design Sampul dan Tata Letak :

Mochamad Nashrullah, S.Pd

\section{Penerbit :}

UMSIDA Press

\section{Redaksi :}

Universitas Muhammadiyah Sidoarjo

J1. Mojopahit No 666B

Sidoarjo, Jawa Timur

\section{Cetakan pertama, Agustus 2017}

(C) Hak cipta dilindungi undang-undang

Dilarang memperbanyak karya tulis ini dengan suatu apapun tanpa ijin tertulis dari penerbit. 


\section{KATA PENGANTAR}

\section{Bismillahirrahmanirrahim}

Syukur Alhamdulillah kami haturkan kehadirat Allah SWT yang telah memberi rahmat dan karuniaNya, sehingga penulis dapat menyelesaikan buku ajar di Fakultas Ilmu Sosial dan Ilmu Politik dengan judul "Islam dan Ilmu Pengetahuan (AIK IV)". Buku ini dimaksudkan sebagai pedoman perkuliahan AIK dalam Ilmu Sosial dan Ilmu Politik agar pendidikan AIK dapat berlangsung sesuai dengan tujuan yang diharapkan baik standart kompetensi, isi, proses dan evaluasi.

Bagian awal dari buku ajar ini memuat pengembangan IPTEKS dalam dunia Islam yang diperdalam dengan pembahasan mengenai Ilmu Sosial dan Ilmu Politik dalam Islam. Dengan harapan agar mahasiswa mampu menguasai dan mengintegrasikan nilai-nilai Islam dalam pengembangan dan penerapan Ilmu pengetahuan terutama bidang Sosial dan Politik.

Ucapan terima kasih kami sampaikan kepada Pimpinan Universitas Muhammadiyah Sidoarjo yang telah memberikan kesempatan kepada penulis dan berbagai pihak yang telah membantu terselesaikannya buku ajar ini. Saran 
dan sumbangsih pemikiran sangat kami harapkan dari seluruh dosen pengampu AIK demi kesempurnaan dan perbaikan selanjutnya.

Akhirnya, semoga kehadiran buku ajar ini bermanfaat demi peningkatan mutu Pendidikan Al-Islam dan Kemuhammadiyahan di Perguruan Tinggi Muhammadiyah.

Sidoarjo, 30 September 2017

Penulis 


\section{DAFTAR ISI}

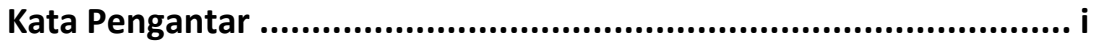

Daftar Isi ....................................................................................

BAB I PENDAHULUAN ....................................................... 1

A. Tujuan Perkuliahan .............................................................. 1

B. Ruang Lingkup dan Materi Perkuliahan ....................................... 1

C. Standar Kompetensi .................................................................. 3

D. Metode Perkuliahan.............................................................. 3

E. Evaluasi Perkuliahan ............................................................... 3

BAB II HAKIKAT IPTEKS DALAM PANDANGAN ISLAM .................. 5

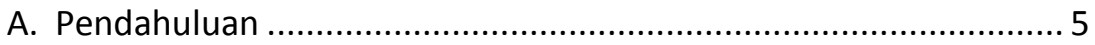

B. Penyajian Materi .................................................................. 5

1. Konsep IPTEKS dan Peradaban Muslim .............................. 5

2. Hubungan Ilmu, Agama dan Budaya ................................ 13

3. Hukum Sunnatullah (Kausalitas) ................................... 17

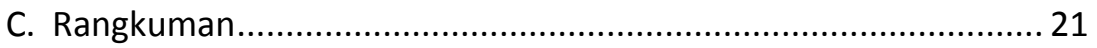

D. Latihan/Tugas/Eksperimen .................................................. 22

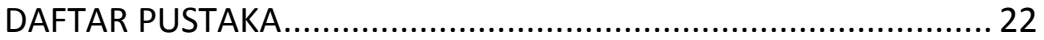

\section{BAB III KEWAJIBAN MENUNTUT ILMU, MENGEMBANGKAN DAN} MENGAMALKANNYA........................................................24

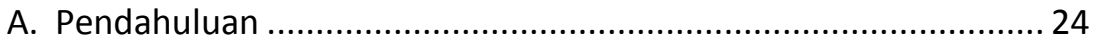

B. Penyajian Materi .................................................................... 24

1. Perintah Menuntut IImu ............................................................ 24

2. Keutamaan Orang Menuntut IImu ........................................ 28

3. Kedudukan Ulama Dalam Islam ........................................ 33

C. Rangkuman..................................................................... 40 
D. Latihan/Tugas/Eksperimen .................................................. 41

DAFTAR PUSTAKA............................................................. 42

BAB IV ETIKA PENGEMBANGAN DAN PENERAPAN IPTEKS DALAM

PANDANGAN ISLAM ........................................................43

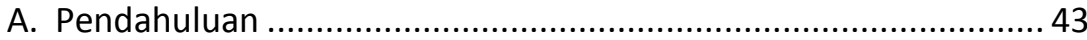

B. Penyajian Materi .............................................................. 44

1. Sinergi Ilmu dan Pengintegrasiannya dengan Nilai dan Ajaran Islam..................................................................... 44

2. Paradigm Ilmu Tidak Bebas Nilai (Value Bound) .................. 50

3. Paradigm Ilmu Bebas Nilai (Value Free) .............................. 53

4. Perlunya Akhlak Islami Dalam Penerapan IPTEKS................. 57

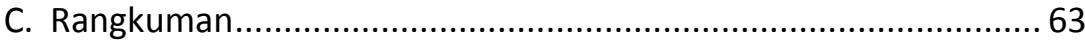

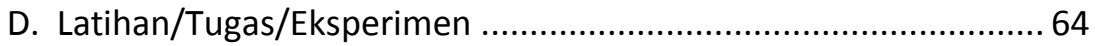

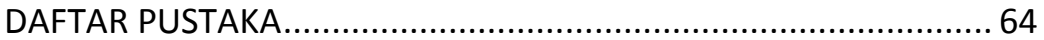

BAB V INTEGRASI ISLAM DAN ILMU PENGETAHUAN....................66

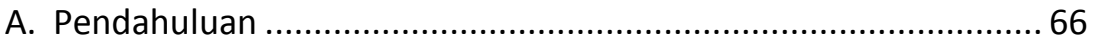

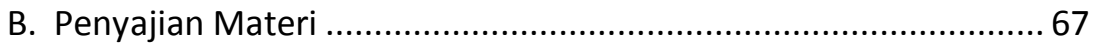

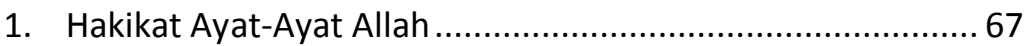

2. Kesatuan antara Ayat Qauliyah dan Kauniyah..................... 74

3. Interkoneksitas dalam Memahami Ayat Qauliyah dan Kauniyah............................................................................ 79

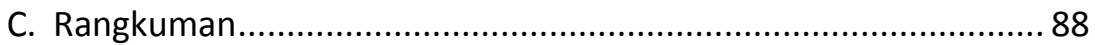

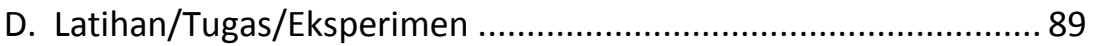

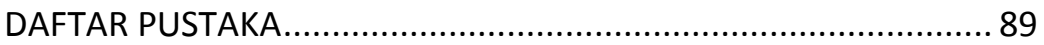

BAB VI PARADIGMA PENGEMBANGAN IPTEKS ..........................91

A. Pendahuluan ......................................................................... 91

B. Penyajian Materi .................................................................. 92

1. Potensi Manusia (Jasmani dan Ruhani) dalam Pengembangan IPTEKS ................................................ 92

2. Rambu-Rambu Pengembangan IPTEKS dalam Al-Qur'an dan Hadits ....................................................................... 105

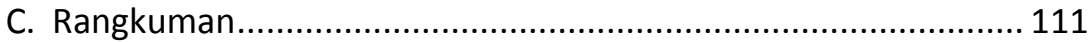


D. Latihan/Tugas/Eksperimen

DAFTAR PUSTAKA

BAB VII Kebenaran Al-Qur'an Dan Hadist Dalam Bidang IImu Sosial Dan Politik.

A. Pendahuluan ....................................................................... 114

B. Penyajian Materi ........................................................ 116

1. Interelasi Kebenaran Al-Qur'an dan Hadist dalam

Bidang Ilmu Sosial dan Politik.

2. Bukti-Bukti Ilmiah Kebenaran Al-Qur'an dan Hadist dalam Bidang Ilmu Sosial dan Politik

C. Rangkuman

D. Evaluasi.....

E. Daftar Pustaka

BAB VIII Paradigma Islam Tentang Ilmu Sosial Dan Politik. 126

A. Pendahuluan ................................................................... 126

B. Penyajian Materi .......................................................... 127

1. Hakikat IImu Sosial dan Politik dalam Perspektif Islam ... 127

2. Keutamaan Mempelajari IImu Sosial dan Politik 136

3. Teori-Teori IImu Sosial dan Politik dalam Islam 138

C. Rangkuman. 146

D. Evaluasi. 147

E. Daftar Pustaka 148 
BAB IX Etika Islam Dalam Penerapan Ilmu Sosial Dan Politik........149

A. Pendahuluan ................................................................. 149

B. Penyajian Materi ...................................................... 151

1. Ilmu Sosial Politik dan Kemanusiaan .......................... 151

2. Ilmu Sosial Politik untuk Kemaslahatan Hidup ............. 156

3. Ayat-Ayat Al-Qur'an dan Hadist yang relevan dengan Etika Ilmu Sosial dan Politik ...................................... 159

C. Rangkuman................................................................ 175

D. Evaluasi......................................................................... 176

E. Daftar Pustaka ........................................................... 176

\section{BAB X Prinsip Dan Ajaran Islam Dalam Penerapan IImu}

Komunikasi ...............................................................178

A. Pendahuluan ............................................................. 178

B. Penyajian Materi ........................................................ 179

1. Komunikasi Transendental ...................................... 179

2. Komunikasi Politik................................................. 182

3. Komunikasi Transaksional ...................................... 186

4. Komunikasi Verbal dan Non Verbal............................ 187

C. Rangkuman............................................................. 188

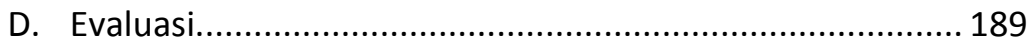

E. Daftar Pustaka ............................................................... 189 
BAB XI Prinsip Dan Ajaran Islam Dalam Penerapan IImu

Administrasi Negara......................................................191

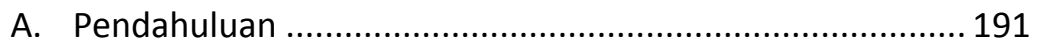

B. Penyajian Materi .......................................................... 192

1. Bentuk dan Sistem Pemerintahan dalam perspektif Islam........................................................................... 192

2. Sistem Administrasi Negara dalam Islam ................... 197

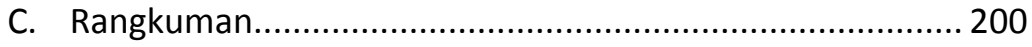

D. Evaluasi........................................................................ 201

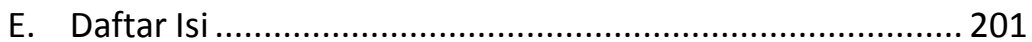

BAB XII Strategi Komunikasi Dakwah ...................................202

A. Pendahuluan ............................................................... 202

B. Penyajian Materi ....................................................... 203

1. Dakwah bil Hal ........................................................ 203

2. Dakwah bil lisan ................................................... 206

3. Ayat dan Hadist yang relevan................................ 212

C. Rangkuman................................................................... 215

D. Evaluasi........................................................................ 216

E. Daftar Isi ..................................................................... 216

BAB XIII Isu-Isu Kontemporer Dalam IImu Sosial Dan Politik .......217

A. Pendahuluan ................................................................ 217

B. Penyajian Materi ............................................................ 218 
1. Upah Muballigh..................................................... 218

2. Dakwah Para Artis .................................................... 219

3. Dakwah Online.................................................... 221

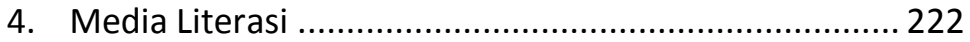

5. Masyarakat Madani .................................................. 223

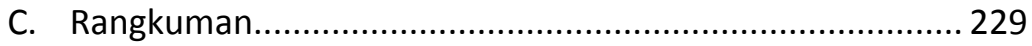

D. Evaluasi.............................................................................. 230

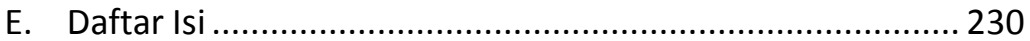




\section{BAB I}

\section{PENDAHULUAN}

\section{A. Tujuan Perkuliahan}

Sesuai dengan pentahapan pemahaman nilai-nilai al-Islam dan Kemuhammadiyahan, pada AIK 4 ini ditekankan pada pengungkapan nilai-nilai yang berkaitan dengan disiplin ilmu masing-masing fakultas. Untuk itu maka tujuan perkuliahan pada AIK 4 ini adalah agar; 1. mahasiswa mampu menerapkan nilai-nilai Islam dalam pengembangan ipteks, 2. mahasiswa mampu mensinergikan nilai-nilai Islam dalam pengembangan ipteks.

\section{B. Ruang Lingkup Materi Perkuliahan}

Secara garis besar materi perkuliahan AIK 4 ini meliputi beberapa bagian. Bagian pertama adalah pendahuluan yang meliputi penjelasan global tentang perkuliahan Al-Islam Kemuhammadiyahan IV yang terdiri atas; a. Tujuan perkuliahan, b. Ruang lingkup materi perkuliahan, c. Standar kompetensi dan kompetensi dasar, d. Metode perkuliahan, serta e. Evaluasi perkuliahan.

Bagian kedua membahas tentang Karya monumental umat Islam dalam IPTEKS, yang terdiri dari; a. Zaman kejayaan Islam di bidang IPTEKS, b. Sebab-sebab kemajuan umat Islam di bidang IPTEKS, c. Sebab-sebab kemunduran umat Islam dalam 
IPTEKS, d. Upaya-upaya kebangkitan kembali umat Islam dalam IPTEKS.

Bagian ketiga membahas hakikat IPTEKS dalam pandangan Islam, yang terdiri dari; a. Kon-sep IPTEKS \& peradaban Muslim, b. Hubungan ilmu, agama \& budaya, c. Hukum sunnatullah (kausalitas).

Bagian keempat membahas Kewajiban menuntut ilmu, mengembangkan dan mengamalkannya, yang terdiri atas; a. Perintah menuntut ilmu, b. Keutamaan orang berilmu, c. Kedudukan ulama dalam Islam.

Bagian kelima membicarakan tentang Etika pengembangan dan penerapan IPTEKS dalam pandangan Islam, yang terdiri atas; a. Sinergi ilmu dan pengintegrasiannya dengan nilai dan ajaran Islam, b. Paradigma ilmu tidak bebas nilai, c. Paradigma ilmu bebas nilai, $d$. Perlunya akhlak Islami dalam penerapan IPTEKS

Bagian keenam membahas Integrasi Islam dan ilmu pengetahuan, yang terdiri atas; a. Hakikat ayat-ayat Allah, b. Kesatuan antara ayat qauliyah dan kauniyah, c. Interkoneksitas dalam memahami ayat qauliyah dan kauniyah.

Bagian ketujuh membahas Paradigma pengembangan IPTEKS, yang terdiri atas; a. Potensi manusia (jasmani dan ruhani) dalam pengembangan IPTEKS, b. Rambu-rambu pengembangan IPTEKS dalam Al-Qur'an 


\section{Standar Kompetensi}

Memahami dan mampu mengintegrasikan nilai-nilai Islam dalam pengembangan dan penerapan ilmu pengetahuan, teknologi dan seni (ipteks). 2. Menghayati dan menerapkan nilai-nilai Islam dalam pengembangan ipteks

\section{Metode Perkuliahan}

Metode perkuliahan akan diawali dengan tutorial untuk menjelaskan tujuan dan ruang lingkup materi serta target yang diharapkan dalam proses perkuliahan serta cara penilaian. Untuk selanjutnya pembahasan materi diharapkan dapat diperdalam melalui kajian literatur yang dilakukan secara berkelompok, dan dipresentasikan dalam seminar kelas. Keseluruhan kegiatan seminar tersebut diagendakan sepanjang tatap muka dalam ruang kuliah sehingga terjadi interaksi akademis antara dosen dan mahasiswa serta di antara mahasiswa sendiri. Setiap tahap seminar akan menghasilkan kesimpulan dan atau rekomendasi secara tertulis.

\section{E. Evaluasi Perkuliahan}

Evaluasi perkuliahan dilakukan dalam dua bentuk, yakni bentuk evaluasi proses dan bentuk evaluasi produk. Evaluasi proses dilakukan melalui pengamatan sepanjang tatap muka dalam perkuliahan meliputi kegiatan seminar (presentasi dan 
tanya jawab), sedangkan evaluasi produk adalah berupa portofolio baik berupa makalah dan atau bahan presentasi atau bentuk karya lainnya, jawaban dalam ujian tengah semester (UTS) dan ujian akhir semester (UAS). Untuk aspek portofolio memiliki bobot $20 \%$, pengamatan selama tatap muka memiliki bobot $20 \%$, sedangkan UTS dan UAS memiliki bobot $60 \%$. 


\section{BAB II}

\section{HAKIKAT IPTEKS DALAM PANDANGAN ISLAM}

\section{A. Pendahuluan}

Ilmu Pengetahuan, Teknologi dan Seni (IPTEKS) dalam pandangan Islam pada bab ini, mengkaji tentang konsep IPTEKS dan peradaban muslim; hubungan agama, ilmu dan budaya; serta hukum sunnatullah atau kausalitas (sebab akibat). Sehingga diharapkan tergambar dengan jelas seperti apa sebenarnya IPTEKS yang harus dipelajari dan bagaimana mengaplikasikannya.

Malalui kajian hakikat IPTEKS dalam pandangan Islam diharapkan mahasiswa dapat:

1. Memahami dan mampu mengintegrasikan nilai-nilai Islam dalam pengembangan dan penerapan ilmu pengetahuan, teknologi dan seni (IPTEKS).

2. Menghayati dan menerapkan nilai-nilai Islam dalam pengembangan IPTEKS.

\section{B. Penyajian Materi}

\section{Konsep IPTEKS dan Peradaban Muslim}

Ilmu Pengetahuan, Teknologi dan Seni (IPTEKS) adalah lapangan kegiatan terus-menerus dikembangkan dalam peradaban Muslim. Hal ini dikarenakan penemuan-penemuan IPTEKS seperti telekominikasi, transportasi, informasi dan 
lainnya telah memudahkan kehidupan, memberikan kesengan dan kenikmatan, sehingga kebutuhan-kebutuhan jasmani tidak sukar lagi pemenuhanannya. Di sisi lain penguasaan dan pengembangan IPTEKS an sich, tanpa mengaitkan dengan nilainilai agama, hanya akan menciptakan intelektual-intelektual yang miskin eksistensi diri dan moralitas (akhlak) yang mulia. Hal ini terbukti dari pemanfaatan sain dan teknologi yang cenderung tak terkontrol, sehingga menimbulkan eksploitasi yang luar biasa, baik dari sisi fisis-biologis maupun dari sisi sosial budaya terhadap kehidupan manusia. Alhasil, eksploitasi dan eksplorasi berlebihan tersebut melahirkan berbagai bencana, baik bencana material maupun moral. Hal ini sematamata merupakan kelalaian dari manusia itu sendiri. Allah SWT selalu mengingatkan kepada manusia dalam firmanNya:

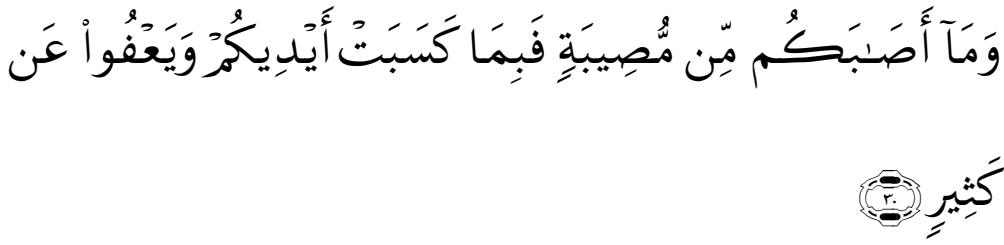

"Dan apa saja musibah yang menimpa kamu Maka adalah disebabkan oleh perbuatan tanganmu sendiri, dan Allah memaafkan sebagian besar (dari kesalahan-kesalahanmu)." (Q.S. As-Syuura [42]: 30)

Tragedi tersebut di atas, menurut Daradjat (1979), disebabkan oleh beberapa faktor yang mempengaruhi cara pandang dan berpikir masyarakat modern, antara lain: (1) 
kebutuhan hidup yang semakin meningkat dan konsumtif; (2) rasa individualistis dan egoistis; (3) persaingan dalam kehidupan; (4) keadaan yang tidak stabil; dan (5) terlepasnya IPTEKS dari agama.

Ilmu yang berkembang di dunia Barat saat ini berdasarkan pada rasio dan pancaindera, jauh dari wahyu dan tuntunan ilahi. Meskipun telah menghasilkan teknologi yang bermanfaat bagi manusia. Di sisi lain, perbudakan terjadi dan kekayaan alam dieksploitasi. Contoh ilmu pengetahuan yang sudah terbaratkan itu (westernized), yaitu yang terjadi pada dunia pertanian sangat berlebihan dalam penggunaan bahanbahan kimia, seperti luasnya penggunaan pestisida, herbisida, pupuk nitrogen sintetis, dan seterusnya, bahkan meracuni bumi, membunuh kehidupan margastwa, bahkan meracuni hasil panen dan mengganggu kesehatan para petani. Pertanian yang semula disebut dengan istilah agriculture (kultur, suatu cara hidup saling menghargai, timbal balik komunal, dan kooperatif, bukan kompetitif) berkembang lebih popular dengan istilah agribusiness, sebuah sistem yang memaksakan tirani korporat untuk memaksimalkan keuntungan dan menekan biaya, menjadikan petani/penduduk lokal yang dahulu punya harga diri dan mandiri lalu berubah menjadi buruh upahan di tanah air sendiri (Setia, 2007).

Dalam dunia kedokteran modern dikenal praktik vivisection (arti harfiahnya "memotong hidup-hidup"), yaitu 
cara menyiksa hewan hidup karena dorongan bisnis untuk menguji obat-obatan agar dapat mengurangi daftar panjang segala jenis penyakit manusia (Croce, 1999). Praktik ini selain tidak beretika keilmuan dan tidak "berperikemanusiaan" juga menyisakan pertanyaan instrinsik tentang asumsi atas tingkat kesamaan uji laboratorium hewan dan manusia yang mengesahkan eksplorasi hasil klinis dari satu ke lainnya.

Sementara itu konsep IPTEK terungkap dalam kenyataan bahwa Al-Qur'an menyebut-nyebut kata akar dan kata turunannya tidak kurang dari 800 kali (Trianto, 2007). Dalam sejarah peradaban Muslim, konsep IPTEKS secara mendalam meresap ke dalam seluruh lapisan masyarakat dan mengungkapkan dirinya dalam sejarah semua intelektual. Gambaran Al-Qur'an tentang spirit pengembangan IPTEKS termaktub dalam Al-Qur'an surat Ar-Rahman ayat 33:

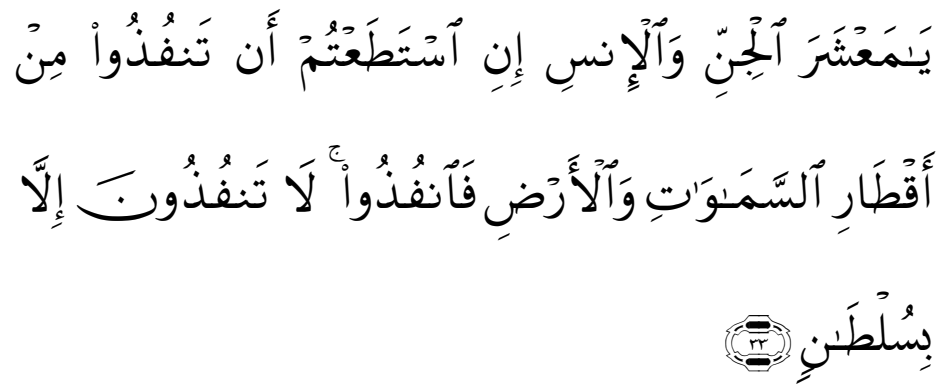

"Hai jama'ah jin dan manusia, jika kamu sanggup menembus (melintasi) penjuru langit dan bumi, Maka 
lintasilah, kamu tidak dapat menembusnya kecuali dengan kekuatan (sains dan teknologi)." (Q.S. Ar-Rahman [55]: 33)

Seruan Allah di atas, merupakan tantangan dan anjuran untuk terus-menerus memajukan IPTEK dengan maksud memahami rahasia-rahasia Allah pada apa yang ada di langit dan di bumi. Melalui penemuan-penemuan akan rahasia Allah tersebut diharapkan tumbuhnya kesadaran akan kekuasaanNya.

Trianto (2007), IPTEKS tersebut hakikatnya adalah alat yang diberikan kepada manusia untuk mengetahui dan mengenal rahasia-rahasia alam ciptaan Allah sebagai khalifah Allah di bumi. Tujuan akhir dari IPTEKS tersebut menurut Islam adalah dalam rangka pengabdian total kepada Allah SWT. Hal ini sesuai firman Allah berikut:

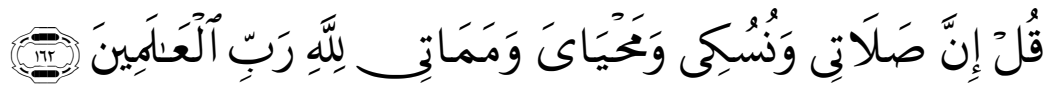

"Katakanlah: Sesungguhnya sembahyangku, ibadatku, hidupku dan matiku hanyalah untuk Allah, Tuhan semesta alam." (Q.S. Al-An'am [6]: 162)

Berdasarkan konsepsi tesebut di atas, jelaslah bahwa manifestasi dan muara seluruh aktivitas IPTES bersifat teosentris. Sebaliknya dalam epistemologi ilmu modern dan kontemporer lebih cenderung bersifat antro sentries (Azra dalam Saridjo, 1999). 
Epistemologi Islam tersebut hakikatnya menghendaki, bahwa IPTEKS harus mengakui adanya nilai-nilai kemanusiaan yang universal. Intisari dari tawaran epistemologi Islam ini adalah bahwa mengaitkan disiplin IPTEKS dengan ideologi Islam sangat mungkin dilakukan, yaitu; dengan jalan membenarkan teori, metode, dan tujuan IPTEKS secara Islami. Bahkan Mulkhan (1998), menilai bahwa epistemologi Islam sangat diperlukan, karena umat Islam merasa ketertinggalan terhadap penguasaan ilmu alat (metodologi) terutama dalam pengertian filosofis. Oleh sebab itu kajian mengenai Islam dalam hubungannya pengembangannya IPTEKS harus dikaji dan diperkanalkan sebagai suatu paradigm baru dalam memandang bahwa antara agama dan IPTEKS merupakan satu kesatuan yang utuh dan bulat.

Sebenarnya tidak ada pertentangan antara Islam dan IPTEKS, ketika IPTEKS diartikan sebagai metode yang rasional dan empiris untuk mempelajari ilmu fenomena alam. Pertentangan itu hanya bisa terjadi, jika IPTEKS dan metodologinya dibuat dalam sebuah nilai trasenden yang mencakup secara menyeluruh dengan mengorbankan nilai-nilai Islam (Butt, 2001).

Menggali ilmu adalah satu-satunya alat untuk mencapai pemahaman yang lebih mendalam tentang sang Pencipta, dan menyelesaikan persoalan masyarakat Islam. Oleh sebab itu IPTEKS dipelajari bukan untuk IPTEKS itu sendiri, akan tetapi 
untuk mendapatkan keridhoan Allah SWT dengan mencoba memahami ayat-ayatNya. Kondisi demikian menurut Butt (2001), yang tidak berada dalam konteks IPTEKS modern, yang memisahkan akal dan wahyu. Akal sering dianggap sebagai segala-galanya, dengan penisbian etika dan nilai yang tidak dapat dielakkan.

Al-Qur'an menekankan bahwa manusia merupakan bagian integral dari alam semesta dan telah dikaruniai dengan kemampuan untuk menguasai kekuatan alam dalam batasbatas tertentu. Hal ini dijelaskan dalam firman Allah berikut:

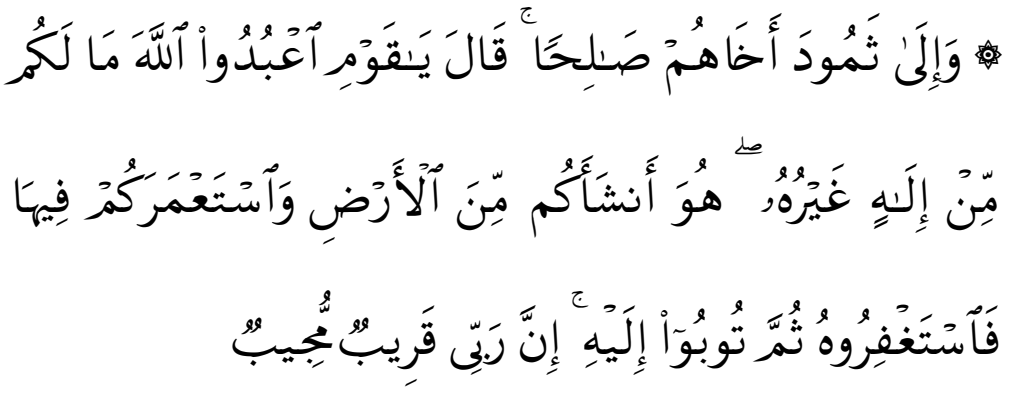

"Dan kepada Tsamud (kami utus) saudara mereka shaleh. Shaleh berkata: "Hai kaumku, sembahlah Allah, sekalikali tidak ada bagimu Tuhan selain Dia. Dia telah menciptakan kamu dari bumi (tanah) dan menjadikan kamu pemakmurnya, karena itu mohonlah ampunan-Nya, kemudian bertobatlah kepada-Nya, sesungguhnya Tuhanku Amat dekat (rahmat-Nya) lagi memperkenankan (doa hamba-Nya)." (Q.S. Huud [11]: 61)

Dengan demikian semakin jelas, bahwa Al-Qur'an menempatkan IPTEKS dalam konteksnya yang layak, yaitu 
dalam rangka pengalaman manusia secara total. Alhasil, anjuran menuntut ilmu memiliki tempat yang penting dalam masyarakat Islam, tetapi tetap tunduk pada nilai-nilai dan etika Islam.

Salah satu prestasi keilmuan dalam peradaban muslim, dapat ditemui dalam berbagai bidang, yaitu bidang matematika, kedokteran, fisika dan astronomi. Bidang matematika dengan tokohnya al-Khawarizmi (w. 833 M) dengan penemuan angka nol yang disebutnya shifr. AlKhawarizmi juga perumus utama "al-Jabar". Nama alKhawarizmi juga diabadikan dalam nama "logaritma" yang diambil dari kata IInggris algorithm dan merupakan transliterasi dari al-Khawarizmi. Dalam bidang kedokteran prestasi umat Islam terlihat dari konstribusi salah seorang ilmuwannya, Ibn Sina (Avicenna) melalui sebuah karya medisnya, al-Qanun fitThibb (The Canon). Karya ini bukan hanya membahas persoalan-persoalan medis, melainkan juga farmasi, farmakologi, dan zoology; di samping ilmu bedah dan saraf. Bidang fisika, terdapat dua tokoh muslim yang menonjol, yaitu al-Biruni (w. 1038 M) dan Ibn Haitsam (w. 1041 M). Al-Biruni dengan penemuannya tentang hukum gravitasi. Selain itu juga berhasil mengukur keliling bumi secara matematis dengan menggunakan rumus-rumus trigonometri. Sementara Ibn Haitsam menemukan bidang optik yang ditulis dalam dalam karyanya al-Manazhir. Ibn Haitsam berhasil menemukan teori 
penglihatan yang memastikan dalam temuannya bahwa sesorang bisa melihat disebabkan objek yang memantulkan cahaya pada kornea mata. Prestasi lainnya bisa dilihat dalam bidang astronomi. Peradaban muslim telah melahirkan banyak astronom besar, seperti al-Battani, al-Farghani, al-Biruni, Nashiruddin at-Thusi, Quthbuddin Syirazi, al-Majrithi dan Ibn Syathir. Temuan astronomi muslim adalah kecenderungannya yang non-Ptolemius dengan mengkritik teori geosentris (Nasr, 1976).

Inilah fakta yang diakui oleh para intelektual sebagai sebuah ciri khas peradaban muslim. Seperti dikatakan oleh Wan Daud (2006): "Para intelektual telah mendapati bahwa salah satu daripada watak khas peradaban muslim ialah perhatiannya yang serius terhadap pencarian pelbagai cabang ilmu". Sebagaimana telah ditegaskannya sebelumnya, watak khas peradaban muslim ini terbentuk oleh budaya ilmu Islam yang universal. Di mana umat Islam, dengan berpedoman pada ajaran-ajaran yang diyakininya, bersikap terbuka terhadap khazanah keilmuan yang berasal dari peradaban lain, dengan tetap pada sikap kritis untuk menyelaraskannya dengan nilai dan tuntutan Islam.

\section{Hubungan IImu, Agama dan Budaya}

Hubungan masalah ilmu, agama dan budaya akan berkaitan dengan posisi akal dalam sistem ajaran agama. 
Dalam ajaran Islam, hampir seluruh perintah dan larangan dalam Al-Qur'an sesungguhnya selalau disinggung latarbelakang akaliahnya, sehingga dapat diterima oleh manusia. Berikutnya, al-Qur'an di banyak tempat juga memberi posisi khusus perbuatan sadar manusia yang terus berkembang akhirnya membentuk suatu format kebudayaan. Kebudayaan secara ringkas dengan demikkian adalah media manusia untuk berhadapan dengan dirinya, alam dan Allah. Di sisi lain fungsi Al-Qur'an sebagai kodifikasi wahyu adalah merupakan cara Allah SWT memberi petunjuk kepada manusia untuk secara terus-menerus membentuk kebudayaannya sebagai proses agar manusia yang taat (perbuatan) memperoleh kebahagiaan hidup (Mulkhan, 1993).

Perkembangan ilmu pengetahuan di satu sisi memang berdampak positif, yakni dapat memperbaiki kualitas hidup manusia. Berbagai sarana modern industri, komunikasi, dan transportasi, misalnya, terbukti amat bermanfaat. Tapi di sisi lain, tidak jarang iptek berdampak negatif karena merugikan dan membahayakan kehidupan dan martabat manusia.

Di sinilah, peran agama sebagai pedoman hidup menjadi sangat penting untuk memberi ruh atau spirit berbagai kehidupan sosial dalam pengembangan ilmu dan kebudayaan berdasarkan kaidah dan prinsip-prinsip ajaran agama. Kehidupan manusia kemudian merupakan proses 
pembentukan suatu tata-kehidupan sebagai realisasi ajaran agama tersebut.

Pola hubungan agama dengan ilmu, Furchan (2002) melihat ada empat pola hubungan, yaitu pola hubungan pertama adalah pola hubungan yang negatif, saling tolak. Apa yang dianggap benar oleh agama dianggap tidak benar oleh ilmu pengetahuan dan teknologi. Demikian pula sebaliknya. Dalam pola hubungan seperti ini, pengembangan iptek akan menjauhkan orang dari keyakinan akan kebenaran agama dan pendalaman agama dapat menjauhkan orang dari keyakinan akan kebenaran ilmu pengetahuan.

Pola hubungan ke dua adalah perkembangan dari pola hubungan pertama. Ketika kebenaran iptek yang bertentangan dengan kebenaran agama makin tidak dapat disangkal sementara keyakinan akan kebenaran agama masih kuat di hati, jalan satu-satunya adalah menerima kebenaran keduanya dengan anggapan bahwa masing-masing mempunyai wilayah kebenaran yang berbeda. Konflik antara agama dan ilmu, apabila terjadi, akan diselesaikan dengan menganggapnya berada pada wilayah yang berbeda. Dalam pola hubungan seperti ini, pengembangan iptek tidak dikaitkan dengan penghayatan dan pengamalan agama seseorang karena keduanya berada pada wilayah yang berbeda.

Pola ke tiga adalah pola hubungan netral. Dalam pola hubungan ini, kebenaran ajaran agama tidak bertentangan 
dengan kebenaran ilmu pengetahuan tetapi juga tidak saling mempengaruhi. Kendati ajaran agama tidak bertentangan dengan iptek, ajaran agama tidak dikaitkan dengan iptek sama sekali. Mendukung ajaran agama tapi ajaran agama tidak mendukung pengembangan iptek, dan ajaran agama mendukung pengembangan iptek dan demikian pula sebaliknya.

Pola hubungan yang ke empat adalah pola hubungan yang positif. Terjadinya pola hubungan seperti ini mensyaratkan tidak adanya pertentangan antara ajaran agama dan ilmu pengetahuan serta kehidupan masyarakat yang tidak sekuler. Secara teori, pola hubungan ini dapat terjadi dalam tiga wujud: ajaran agama mendukung pengembangan IPTEKS tapi pengembangan iptek tidak mendukung ajaran agama, pengembangan ilmu.

Sementara itu, hubungan agama dengan budaya. Istilah agama maupun religi menunjukkan adanya hubungan antara manusia dan kekuatan gaib di luar kekuasaan manusia, berdasarkan keyakinan dan kepercayaan menurut paham atau ajaran agama. Agama sukar dipisahkan dari budaya karena agama tidak akan dianut oleh umatnya tanpa budaya. Agama tidak tersebar tanpa budaya, begitupun sebaliknya, budaya akan tersesat tanpa agama (Sutardi, 2007).

Ajaran agama ketika disandingkan dengan nilai-nilai budaya lokal di era desentralisasi dapat diserap untuk dijadikan 
pengangan kehidupan bermasyarakat. Hal ini dapat dilihat dengan diberikannya otonomi khusus kepada Aceh yang dikenal dengan Nanggroe Aceh Daussalam. Agama dan budaya di NAD sudah melebur dan tidak bisa dipisahkan sejak dahulu, ketika kerajaan Islam masih ada di wilayah tersebut. Dengan otonomi khusus ini hokum pidana Islam kembali dihidupkan sehingga masyarakat merasakan keadilan sesuai dengan keyakinannya. Hal ini menjadi awal yang baik dalam menciptakan kesejahteraan masyarakat dengan mengangkat agama dan budaya yang ada di masyarakat tersebut (Sutardi, 2007). Pada masyarakat yang menjunjung tinggi nilai-nilai tradisi leluhurnya, perilaku keagamaan juga memberikan dampak yang cukup berarti.

\section{Hukum Sunnatullah (Kausalitas)}

Hukum sunnatullah atau kausalitas (sebab akibat) pada dasarnya telah muncul seumur dengan peradaban manusia, bahkan seusia dengan alam ini dan realitas eksistensi itu sendiri. Manusia sebagai makhluk yang berakal berupaya mencari sebab-sebab dari setiap kejadian. Dengan mengetahui sebabnya berarti memahami akar dan sumber akibat atau kejadian.

Sunnatullāh dapat diartikan sebagai cara Allah memperlakukan manusia, yang dalam arti luasnya bermakna ketetapan-ketetapan atau hukum-hukum Allah yang berlaku 
untuk alam semesta (Hidayat, 1996). Dengan demikian, sunatullah adalah ketentuan Allah. Suatu ketentuan hukum Logika yang mempunyai hubungan sebab akibat dalam kajian ilmiah (Scientific) disebut dengan hukum alam.

Berdasarkan konsep tersebut di atas, sunnatullah merupakan hukum yang ditetapkan Allah yang bersifat fitrah, yakni tetap dan otomatis, untuk mengatur mekanisme alam semesta sehingga dapat menjadi pedoman bagi manusia dalam beribadah kepada Allah selaku hamba-Nya dan dalam mengelola alam semesta selaku khalifatullah, guna mewujudkan maslahat bagi kehidupan manusia dan menghindari mafsadat. Sunnatullah merupakan hukum ciptaan Allah yang paling awal sebelum Allah menciptakan manusia dan menurunkan syariah-Nya. Sunnatullah ini memiliki beberapa spesifikasi atau karakteristik, antara lain, sebagai berikut:

a. Sunnatullah mengatur pergerakan alam semesta dengan seluruh isinya, termasuk pula manusia. Allah menyatakan hal ini dalam firman-Nya:

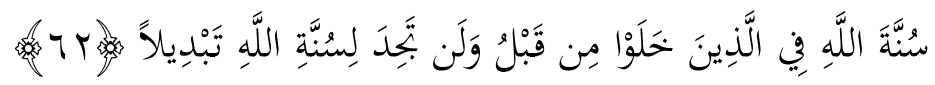

"Sebagai sunnah Allah yang berlaku atas orang-orang yang telah terdahulu sebelum (mu), dan kamu sekali-kali tiada akan mendapati perubahan pada sunnah Allah." (Q.S. AlAhzab [33]: 62) 
b. Sunnatullah memiliki sifat fitrah, yakni tetap dan otomatis. Sifat fitrahnya sunnatullah ini juga dinyatakan dalam firmanNya yang lain dimana Allah menyatakan:

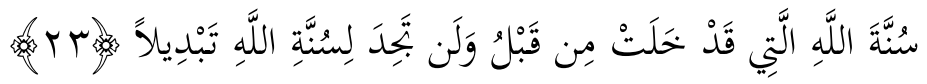

"Sebagai suatu sunnatullah yang telah berlaku sejak dahulu, kamu sekali-kali tiada akan menemukan perubahan bagi sunnatullah itu." (Q.S. Al-Fath [48]: 23)

c. Penciptaan manusia tunduk pada fitrah Allah. Allah menciptakan manusia melalui proses hukum alam yang berjalan menurut fitrahnya, yakni tetap dan otomatis. Fitrah penciptaan manusia ini tidak akan mengalami perubahan sebagaimana dinyatakan Allah dalam firman-Nya:

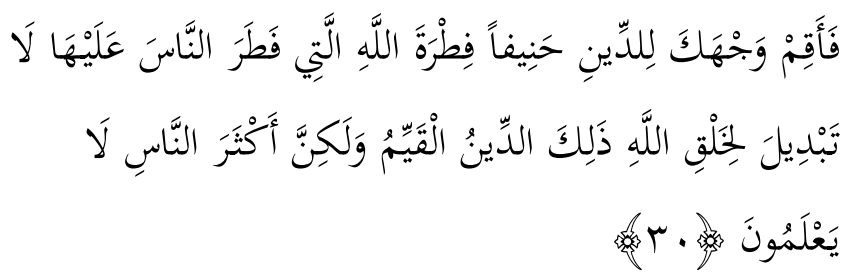

"Maka hadapkanlah wajahmu dengan lurus kepada agama (Allah); (tetaplah atas) fitrah Allah yang telah menciptakan manusia menurut fitrah itu. Tidak ada perubahan pada fitrah Allah. (Itulah) agama yang lurus; tetapi kebanyakan manusia tidak mengetahui." (Q.S. Al-Ruum [30]: 30) 
Allah SWT menjelaskan di dalam firman-Nya bagaimana penciptaan manusia ini sebagai berikut:

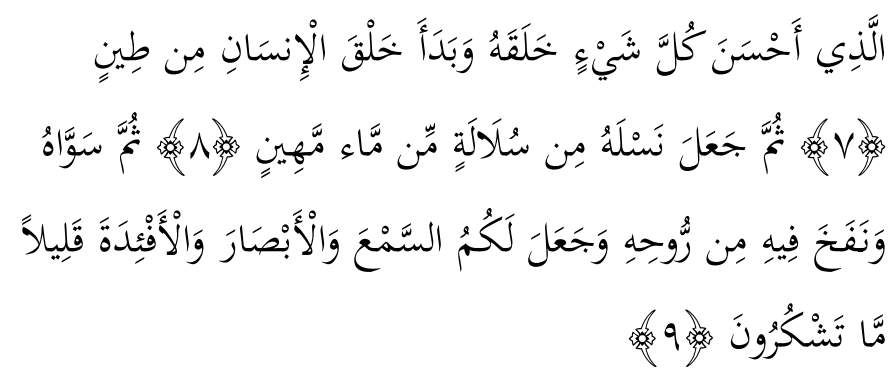

"(Allah) Yang membuat segala sesuatu yang Dia ciptakan sebaik-baiknya dan Yang memulai penciptaan manusia dari tanah. Kemudian Dia menjadikan keturunannya dari saripati air yang hina (air mani). Kemudian Dia menyempurnakan dan meniupkan ke dalam (tubuh) nya roh (ciptaan)-Nya dan Dia menjadikan bagi kamu pendengaran, penglihatan, dan hati; (tetapi) kamu sedikit sekali bersyukur." (Q.S. alSajdah [32]: 7-9)

d. Obyek hukum sunnatullah adalah alam semesta. Kejadian yang terjadi karena kekuatan hukum alam disebut peristiwa alam.

e. Alam semesta bukan merupakan subyek hukum sunnatullah yang memiliki pilihan dan tanggung jawab, melainkan 
merupakan obyek hukum yang secara otomatis tunduk pada hukum sunnatullah.

f. Alam semesta sebagai obyek hukum sunnatullah dapat terjadi perubahan atau perkembangan. Perubahan alam tersebut terjadi karena ketetapan hukum alam, artinya perubahan alam terjadi karena diatur oleh hukum alam. Hukum alamlah yang menyebabkan perubahan alam. Namun demikian, meskipun alam semesta dapat berubah, tetapi hukum alam tidak akan berubah, dan perubahan alam senantiasa tunduk pada hukum alam.

g. Mekanisme kerja hukum alam terbebas dari campurtangan akal dan kehendak manusia. Allah dalam menetapkan hukum sunnatullah ini terbebas dari campurtangan pemikiran dan keinginan manusia. Bahkan pemikiran dan kehendak manusia terhadap alam semesta dan aturan hukumnya tunduk pada sunnatullah. Tidak ada tempat sama sekali bagi manusia untuk ikut campur tangan dalam menetapkan hukum sunnatullah untuk mengatur alam semesta.

\section{Rangkuman}

1. IPTEKS hakikatnya adalah alat yang diberikan kepada manusia untuk mengetahui dan mengenal rahasia-rahasia alam ciptaan Allah sebagai khalifah Allah di bumi dalam rangka pengabdian total kepada Allah SWT. 
2. Hukum sunnatullah atau kausalitas (sebab akibat) merupakan hukum yang ditetapkan Allah yang bersifat fitrah, yakni tetap dan otomatis, untuk mengatur mekanisme alam semesta sehingga dapat menjadi pedoman bagi manusia dalam beribadah kepada Allah selaku hambaNya dan dalam mengelola alam semesta selaku khalifatullah, guna mewujudkan maslahat bagi kehidupan manusia dan menghindari mafsadat.

\section{Latihan/Tugas/Eksperimen}

Mengidentifikasi dan menjelaskan ayat-ayat Al-Qur'an terkait bukti-bukti ilmiah dan isyarat terhadap kejadian-kejadian alam yang telah dibuktikan oleh penemuan ilmiah modern. Ayatayat tersebut adalah: (1) Kecepatan cahaya; (2) Eksistensi alam; (3) Angin; (4) Gerakan bumi; (5) Bahasa binatang; (6) Sidik jari; (7) Isyarat kepada gaya daya tarik bumi; (8) Isyarat bahwa semua materi adalah berpasanga-pasangan; (9) Isyarat kepada adanya pita rekaman; dan (10) Isyarat bahwa adanya gelombang suara.

\section{DAFTAR PUSTAKA}

Butt, Nasim. 2001. Science and Moslim Society. London: Grey Seal Books.

Croce, Pietro. 1999. Vivisection or Science: An Investigation into Testing Drugs and Safeguarding Health. London: Zed Books. 
Daradjat, Zakiah. 1979. Ilmu Jiwa Agama. Jakarta: Bulan Bintang.

Furchan, Arief. H. 2002. Transformasi Pendidikan Islam di Indonesia: Anatomi Keberadaan Madrasah dan PTAI. Yogyakarta: Gama Media.

Hidayat, Rahmat Taufiq. 1996. Khazanah Istilah Al Quran. Bandung: Mizan.

Mulkhan, Abdul Munir. 1993. Paradigma Intelektual Muslim.: Pengantar Filsafat Pendidikan Islam dan Dakwah. Yogyakarta: SIPRESS.

Nasr, Seyyed Houssen. 1976. Islamic Sciences: An Illustrated Study. London: Wold of Islam Festival Publishing co. Itd.

Setia, Adi. 2007. Three Meanings of Islamic Science Toward Operasionalizing of Knowledge. Center for Islam and Science: Free online Library.

Sila, Muhammad Adlin. 1998. "Islamisasi Sains dan Teknologi di Institut Teknologi Bandung." Penamas. Jurnal Penelitian Agama dan Kemasyarakat Balit Agama dan Kemasyarakatan. Nomor 32. Th. XI/1998. h. 34-48.

Sutardi, Tedi. 2007. Antropologi Mengungkap Keragaman Budaya. Bandung: PT. Setia Purna.

Wan Daud, Wan Hohd. Nor. 2006. Masyarakat Islam Hadhari: Suatu Tinjauan Epistemologi dan Kependidikan ke Arah Penyatuan Pemikiran Bangsa. Kuala Lumpur: Dewan Bahasa dan Pustaka. 


\section{BAB III}

\section{KEWAJIBAN MENUNTUT ILMU, MENGEMBANGKAN DAN MENGAMALKANNYA}

\section{A. Pendahuluan}

Bahasan materi kewajiban menuntut ilmu, mengembangkan dan mengamalkannya pada bab ke 3 ini, meliputi perintah menuntut ilmu, keutamaan orang menuntut ilmu dan kedudukan ulama dalam Islam. Malalui kajian pada bab ini diharapkan mahasiswa dapat menerapkan nilai-nilai keutamaan menuntut ilmu dalam kehidupan sehari-hari.

\section{B. Penyajian Materi}

\section{Perintah Menuntut IImu}

Al-Qur'an tidak secara langsung mengutarakan tentang kewajiban mencari ilmu atau mengembangkan ilmu pengetahuan, namun ayat tersebut tersirat dalam beberapa ayat yang mengisyaratkan tentang hal itu. Berikut ini ayat yang menunjukkan kewajiban menuntut ilmu:

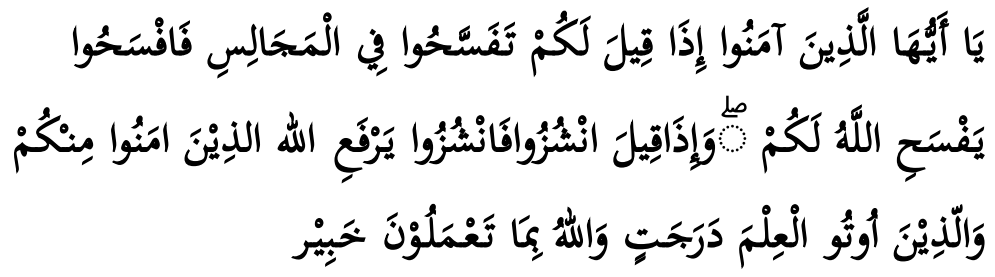


"Wahai orang-orang yang beriman!Apabila dikatakan kepadamu,"Berilah kelapangan didalam majelis, maka lapangkanlah, niscaya Allah akan memberi kelapangan untukmu. Dan apabila dikatakan berdirilah kamu, maka berdirilah, niscaya Allah akan mengangkat derajat orangorang yang beriman diantara kamu dan orang-orang yang berilmu beberapa derajat." (Q.S. Al-Mujadilah [58]: 11 )

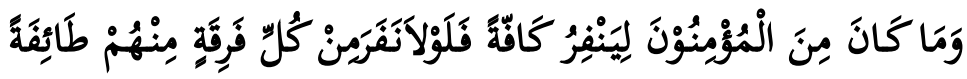

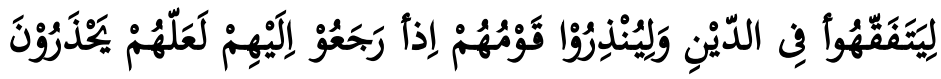

"Dan tidak sepatutnya orang-orang mukmin itu semuanya pergi kemedan perang, mengapa sebagian diantara mereka tidak pergi untuk memperdalam ilmu pengetahuan agama mereka dan untuk memberi peringatan kepada kaumnya apabila mereka telah kembali, agar mereka dapat menjaga dirinya." (Q.S. AtTaubah [9]: 122)

Berdasarkan Surat al-Mujadilah ayat 11 tersebut di atas, menjadi jelaslah bahwa menuntut ilmu adalah merupakan perintah lansung dari Allah. karena orang yang menuntut ilmu akan diangkat derajatnya oleh Allah beberapa derajat, sedangkan Surat Taubah ayat 122 menjelaskan bahwa diwajibkan untuk menuntut ilmu agama dan kedudukan orang yang menuntut ilmu harus mampu menjadi pengingat bagi 
orang yang tidak mengetahui masalah agama serta mampu menjaga diri dari hal-hal yang bisa menjerumuskan ke dalam lembah kenistaan.

Dengan demikian, Ilmu menempati posisi yang sangat penting dalam Islam. Penekanan kepada ilmu dalam Islam sangat jelas terlihat dalam Al-Qur'an dan sunnah Nabi SAW. Di antaranya adalah al-Qur'an surat al-'Alaq ayat 1-5 yang memberikan tekanan pada pembacaan sebagai wahana penting dalam usaha keilmuan, dan pengukuhan kedudukan Allah SWT sebagai sumber tertinggi ilmu pengetahuan manusia.

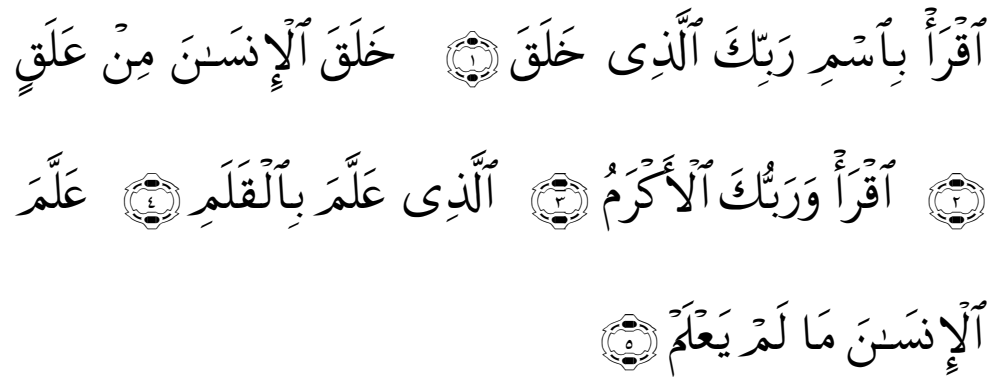

"1. bacalah dengan (menyebut) nama Tuhanmu yang Menciptakan, 2. Dia telah menciptakan manusia dari segumpal darah. 3. Bacalah, dan Tuhanmulah yang Maha pemurah, 4. yang mengajar (manusia) dengan perantaran kalam, 5. Dia mengajar kepada manusia apa yang tidak diketahuinya." (Q.S. al-A'laq [96]: 1-5) 
Sementara Nabi SAW menegaskan dalam hadits yang terkenal sebagai berikut:

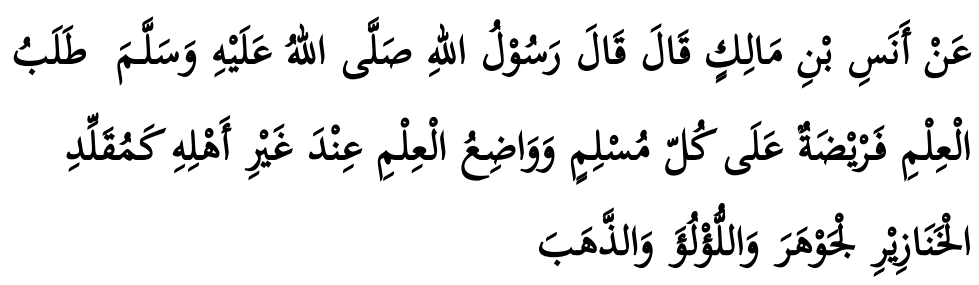

"Dari Anas bin Malik ia berkata; Rasulullah SAW. bersabda: Menuntut ilmu adalah kewajban bagi setiap muslim. Dan orang yang meletakkan ilmu bukan pada ahlinya, seperti seorang yang mengalungkan mutiara, intan dan emas ke leher babi." (HR. Ibnu Majah: 220)

Berdasarkan hadits tersebut di atas mengandung pengertian, bahwa mencari ilmu itu wajib bagi setiap muslim, kewajiban itu berlaku bagi laki-laki maupun perempuan, anakanak maupun orang dewasa dan tidak ada alasan untuk malas mencari ilmu. Ilmu yang wajib diketahui oleh setiap muslim adalah ilmu-ilmu yang berkaitan dengan tata cara peribadatan kepada Allah SWT. Sedangkan ibadah tanpa ilmu akan mengakibatkan kesalahan-kesalahan dan ibadah yang salah tidak akan dapat diterima oleh Allah. Sedangkan orang yang mengajarkan ilmu kepada orang yang tidak mengetahui atau tidak paham maka akan sia-sia. Maksudnya, ilmu itu harus disampaikan sesuai dengan taraf berfikir si penerima ilmu, 
memberikan ilmu secara tidak tepat diibaratkan mengalungkan perhiasan pada babi, meskipun babi diberikan perhiasan kalung emas maka babi tetap kotor dan menjijikkan.

\section{Keutamaan Orang Menuntut IImu}

Penekanan terhadap pentingnya ilmu dapat terlihat juga dari kedudukan orang-orang yang mencari, memiliki, mengajarkan dan mengamalkan ilmu ('ulama). Al-Qur'an menegaskan bahwa sangat berbeda sekali antara orang yang mengetahui dan orang yang tidak mengetahui. Allah SWT berfirman sebagai berikut:

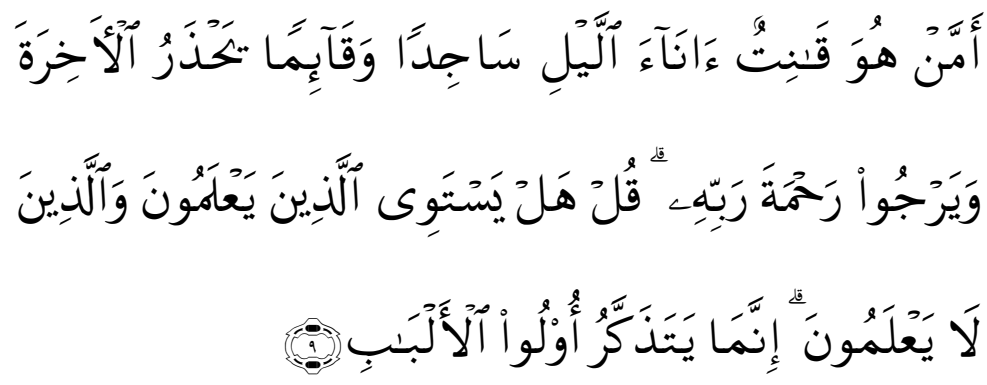

"(apakah kamu Hai orang musyrik yang lebih beruntung) ataukah orang yang beribadat di waktu-waktu malam dengan sujud dan berdiri, sedang ia takut kepada (azab) akhirat dan mengharapkan rahmat Tuhannya? Katakanlah: "Adakah sama orang-orang yang mengetahui dengan orang-orang yang tidak mengetahui?" Sesungguhnya orang yang berakallah yang dapat menerima pelajaran." (Q.S. Az-Zumar [39]: 9) 
Orang-orang yang berilmu dan menyibukkan dirinya dalam mejelis-majelis keilmuan, tentunya di samping juga mereka beriman, dalam penilaian Allah SWT memiliki derajat yang sangat terhormat (Q.S. Al-Mujadilah [58]: 11).

Demikian juga, semua pencari ilmu, tegas Nabi SAW. Akan dimudahkan jalannya ke surga. Para malaikat akan menghormatinya dengan meletakkan sayap-sayapnya. Seluruh makhluk yang ada di bumi, sampai ikan-ikan yang ada di laut terdalam sekalipun, akan memohonkan ampunan. Itu sebabnya kemulaian mereka yang jika dibandingkan dengan orang-orang ahli ibadah yang kurang ilmunya ibarat bulan purna di tengah gugusan bintang-bintang. Mereka semua adalah para pewaris Nabi. Di tangan merekalah ilmu para Nabi, yang lebih berharga daripada dinar dan emas.

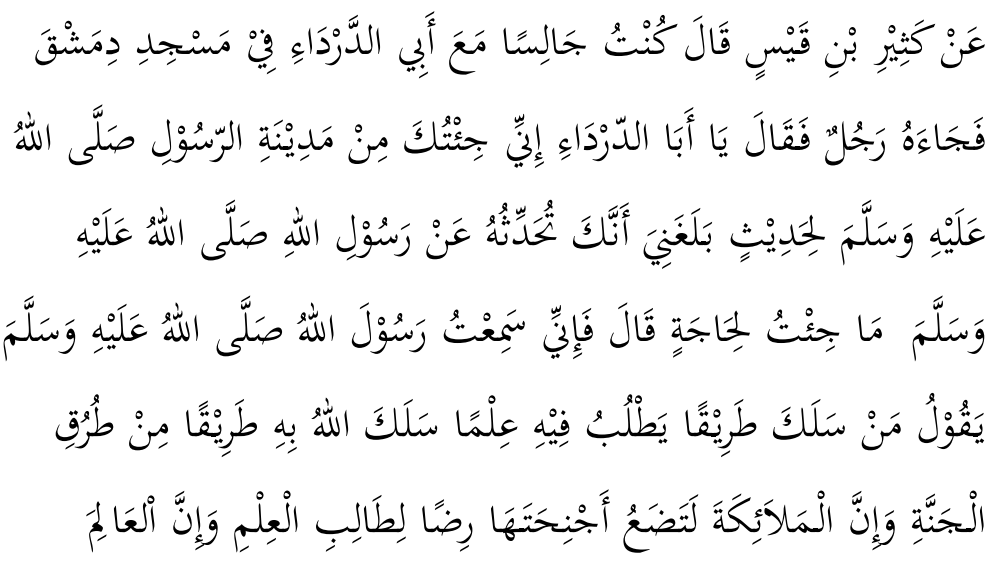




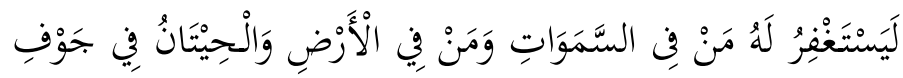

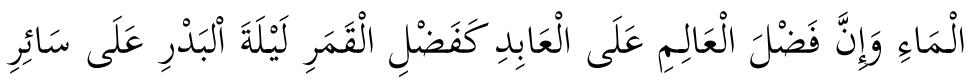

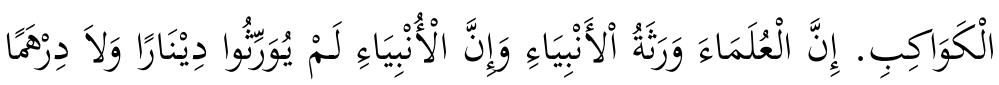

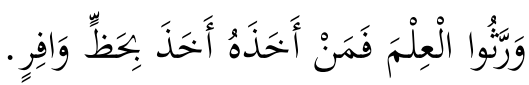

"Dari Katsir bin Qais ia berkata, "Aku pernah duduk bersama Abu Ad-Darda di Masjid Damaskus, lalu datanglah seorang laki-laki kepadanya dan berkata, "Wahai Abu Ad-Darda, sesungguhnya aku datang kepadamu dari kota Rasulullah SAW karena sebuah hadits yang sampai kepadaku bahwa engkau meriwayatkannya dari Rasulullah SAW. Dan tidaklah aku datang kecuali untuk itu." Abu Ad-Darda lalu berkata, "Aku mendengar Rasulullah SAW bersabda: "Barangsiapa yang berjalan menuntut ilmu, maka Allah akan memudahkannya jalan ke surga. Sungguh para Malaikat merendahkan sayapnya sebagai keridlaan kepada penuntut ilmu. Orang yang berilmu akan dimintakan maaf oleh penduduk langit dan bumi hingga ikan yang ada di dasar laut. Kelebihan seorang alim disbanding ahli ibadah seperti keutamaan rembulan pada malam purnama atas seluruh bintang. Para ulama adalah pewaris para nabi, dan para nabi tidak mewariskan dinas dan dirham, mereka hanyalah mewariskan ilmu. Barangsiapa mengambilnya, maka ia telah mengambil bagian yang banyak." (HR. Abu Dawud: 3157) 
Secara khusus Nabi SAW. juga menjamin bahwa orang yang berilmu dan ilmunya tersebut bermanfaat bagi orang lain, maka pahalanya akan terus mengalir walau orang yang bersamgkutan telah meninggal dunia.

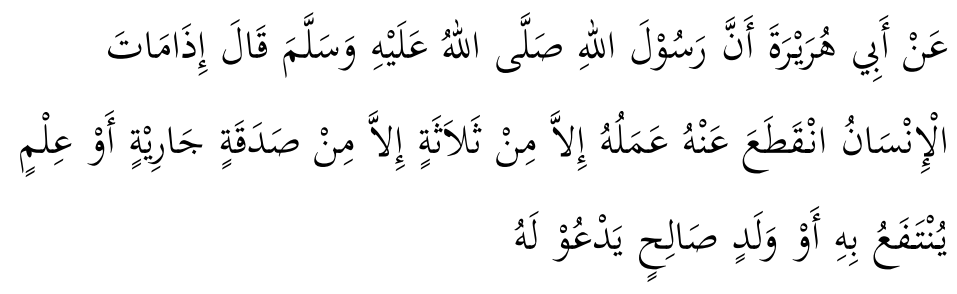

"Dari Abu Hurairah, bahwa Rasulullah SAW. bersabda: "Apabila salah seorang manusia meninggal dunia, maka terputuslah segala amalannya kecuali tiga perkara; sedekah jariyah, ilmu yang bermanfa'at baginya dan anak shalih yang selalu mendoakannya." (HR. Muslim: 3084)

Ilmu nafi' (yang bermanfaat) yang tersebut dalam hadits di atas adalah ilmu yang pernah diperintahkan oleh Allah kepada Nabi Muhammad SAW. agar diminta dan dicari setiap saat (Husaini, 2013). Dalam hal ini Allah SWT berfirman kepada NabiNya sebagai berikut:

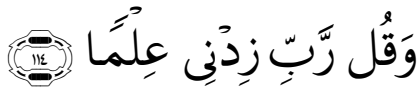

"dan Katakanlah: "Ya Tuhanku, tambahkanlah kepadaku ilmu pengetahuan." (Q.S Thahaa [20]: 114) 
Melalui ayat ini, Rasulullah SAW. diperintahkan untuk senantiasa memohon kepada Allah tambahan ilmu yang bermanafaat. Ibnu Uyainah berkata, "Rasulullah SAW. tidak henti-hentinya memohon tambahan ilmu nafi' kepada Allah sampai beliau wafat" (Katsir, 2002). Ibnu Katsir menambahkan bahwa Rasulullah SAW. tidak pernah diperintahkan untuk tambahan apapun kecuali tambahan ilmu nafi' ini. Oleh karena itu, Rasulullah SAW. senantiasa istiqamah melantunkan do'a ilmu nafi' sebagai berikut:

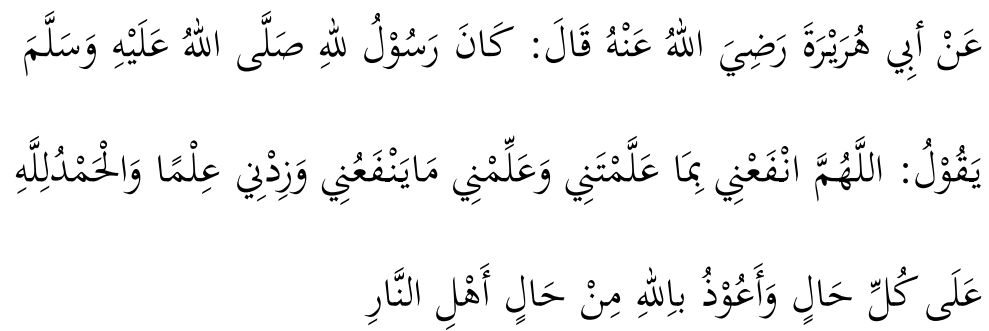

"Dari Abi Hurairah r.a. bahwa Rasulullah SAW senantiasa membaca do'a, "Ya Allah, berikanlah manfaat terhadap apa yang telah Engkau ajarkan kepadaku, dan ajari aku apa yang bermanfaat bagiku, dan tambahilah aku ilmu. Segala puji hanya milikmu atas segala keadaan dan aku berlindung dai perilaku ahli neraka." (HR. Tirmidzi).

Oleh karena itu, Rasulullah SAW. memerintahkan kepada umatnya agar belajar ilmu nafi' dan meninggalkan ilmu yang ghairu nafi' sebagaimana terdapat dalam sabdanya, 


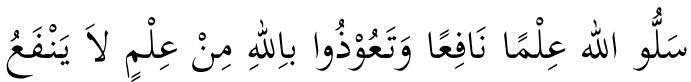

"Mintalah kepada Allah ilmu yang bermanfaat, dan berlindunglah kepada Allah dari ilmu yang tidak bermanfaat." (HR. Ibn Majah: 3843)

Ibn Jauzi mengidentifikasikan bahwa ilmu yang bermanfaat akan mendatangkan khasyah 'takut' kepada Allah, dan pemiliknya senantiasa mengakui keagungan Allah, sehingga melahirkan tahqiq ubudiyah, yaitu ketundukkan dan penghambaan kepadaNya. Sebaliknya, ilmu yang tidak mendatangkan khasyah, tidak disebut sebagai ilmu yang bermanfaat dan pemiliknya tidak masuk dalam kategori alim (Jauzi, tt.).

\section{Kedudukan Ulama Dalam Islam}

Allah menjadikan mereka (para ulama) sebagai makhluk yang berkedudukan tinggi setelah malaikat, dalam masalah kesaksian keesaan Allah SWT. Hal ini sebagaimana firman Allah SWT berikut ini: 


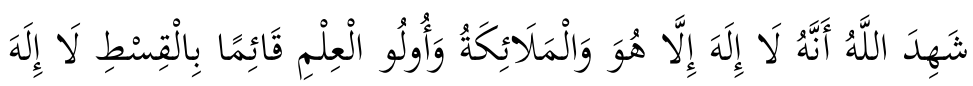

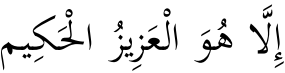

"Allah menyatakan bahwasanya tidak ada Tuhan melainkan Dia, Yang menegakkan keadilan. Para malaikat dan orang-orang berilmu (juga menyatakan demikian itu). Tak ada Tuhan melainkan Dia, Yang Maha Perkasa lagi Maha Bijaksana." (Q.S. Ali Imram [3]: 18)

Allah SWT juga akan mengangkat derajat orang-orang beriman dan berilmu pengetahuan (ulama) pada derajat lebih tinggi serta mendapatkan pahala yang besar.

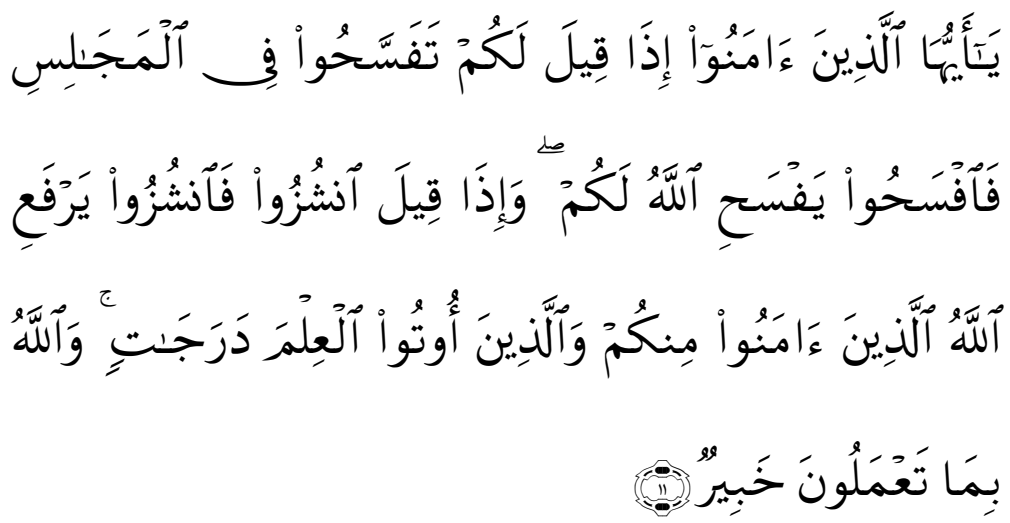


"Hai orang-orang beriman apabila kamu dikatakan kepadamu: "Berlapang-lapanglah dalam majlis", Maka lapangkanlah niscaya Allah akan memberi kelapangan untukmu. dan apabila dikatakan: "Berdirilah kamu", Maka berdirilah, niscaya Allah akan meninggikan orang-orang yang beriman di antaramu dan orang-orang yang diberi ilmu pengetahuan beberapa derajat. dan Allah Maha mengetahui apa yang kamu kerjakan." (Q.S. Al-Mujaadilah [58]: 11)

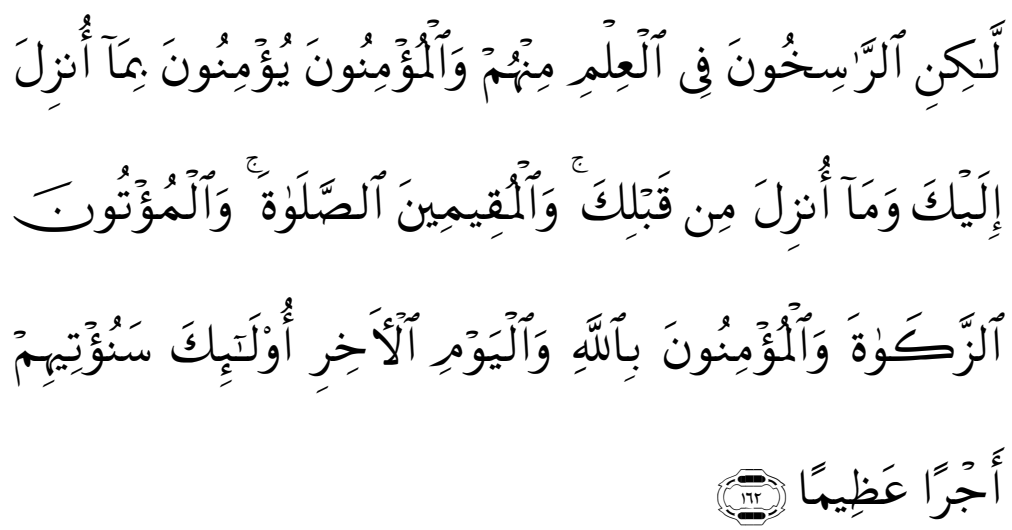

"Tetapi orang-orang yang mendalam ilmunya di antara mereka dan orang-orang mukmin, mereka beriman kepada apa yang telah diturunkan kepadamu (Al Quran), dan apa yang telah diturunkan sebelummu dan orangorang yang mendirikan shalat, menunaikan zakat, dan yang beriman kepada Allah dan hari kemudian. orangorang Itulah yang akan Kami berikan kepada mereka pahala yang besar." (Q.S. An-Nisaa' [4]: 162) 
Nabi SAW, juga menegaskan bahwa ulama adalah pewaris para Nabi. Hal ini sesuai hadits yang diriwayat oleh Abu Dawud sebaga I berikut:

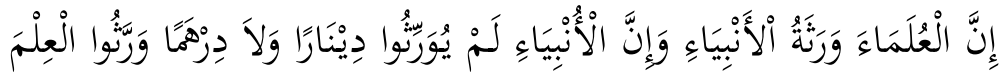

"Para ulama adalah pewaris para nabi, dan para nabi tidak mewariskan dinas dan dirham, mereka hanyalah mewariskan ilmu." (HR. Abu Dawud: 3157)

Berdasar hadits di atas, bahwa ulama adalah ahli waris nabi karena itu ulama mempunyai tugas sesuai dengan apa yang dikerjakan nabi (Ghofur, 2007). Tugas-tugas tersebut diantaranya adalah :

a. Menyampaikan ajaran kitab suci itu secara baik dan bijaksana dengan tidak mengenal takut dan siap menanggung resiko. Hal ini sebagaimana firman Allah SWT berikut:

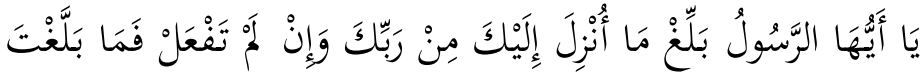

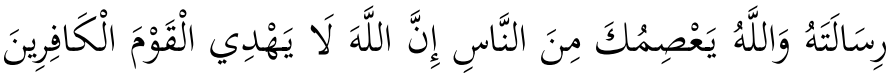


"Hai Rasul, sampaikanlah apa yang diturunkan kepadamu dari Tuhanmu. Dan jika tidak kamu kerjakan (apa yang diperintahkan itu, berarti) kamu tidak menyampaikan amanat-Nya. Allah memelihara kamu dari (gangguan) manusia. Sesungguhnya Allah tidak memberi petunjuk kepada orang-orang yang kafir." (Q.S. Al-Maa'idah [5]: 67)

b. Menjelaskan kandungan kitab suci.

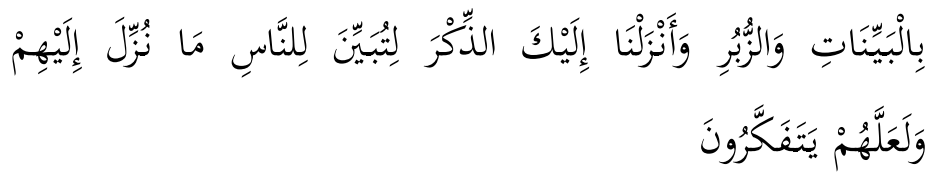

"Keterangan-keterangan (mukjizat) dan kitab-kitab. Dan Kami turunkan kepadamu Al Quran, agar kamu menerangkan pada umat manusia apa yang telah diturunkan kepada mereka dan supaya mereka memikirkan.” (Q.S. An-Nahl [16]:44)

c. Membawa kabar gembira, memberi peringatan, mengajak kepada Allah dan memberi cahaya.

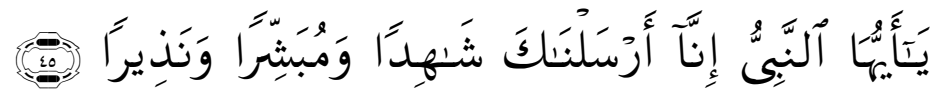

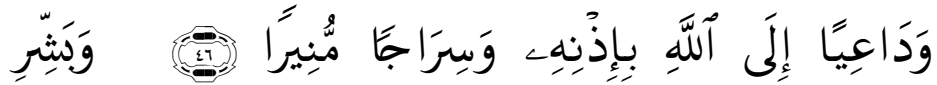

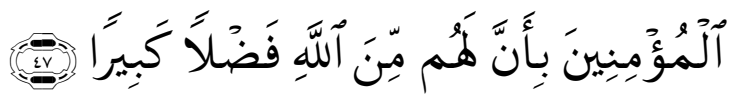


“45. Hai Nabi, Sesungguhnya Kami mengutusmu untuk Jadi saksi, dan pembawa kabar gemgira dan pemberi peringatan, 46. dan untuk Jadi penyeru kepada agama Allah dengan izin-Nya dan untuk Jadi cahaya yang menerangi. 47. dan sampaikanlah berita gembira kepada orang-orang mukmin bahwa Sesungguhnya bagi mereka karunia yang besar dari Allah." (Q.S. Al-Ahzab [33]: 45-47)

d. Memberi putusan atas problem yang terjadi di masyarakat.

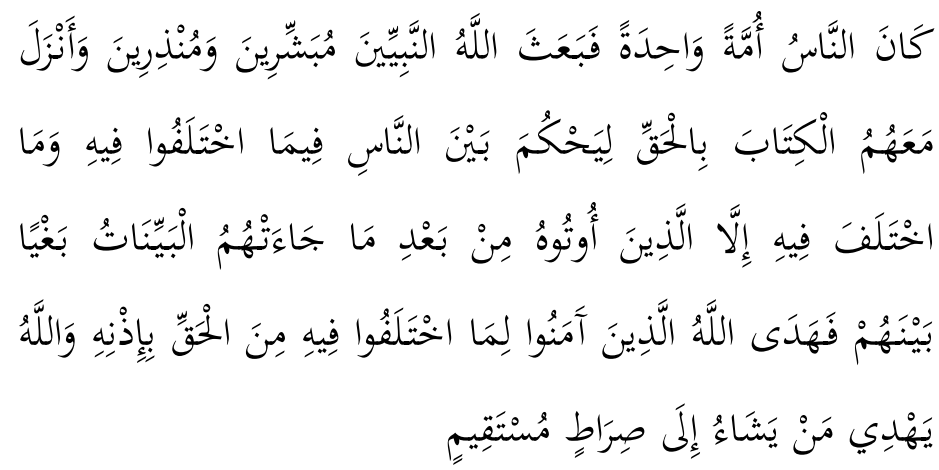

"Manusia itu adalah umat yang satu. (setelah timbul perselisihan), maka Allah mengutus para nabi, sebagai pemberi peringatan, dan Allah menurunkan bersama mereka Kitab yang benar, untuk memberi keputusan di antara manusia tentang perkara yang mereka perselisihkan. Tidaklah berselisih tentang Kitab itu melainkan orang yang telah didatangkan kepada mereka Kitab, yaitu setelah datang kepada mereka keteranganketerangan yang nyata, karena dengki antara mereka sendiri. Maka Allah memberi petunjuk orang-orang yang beriman kepada kebenaran tentang hal yang mereka perselisihkann itu dengan kehendak-Nya. Dan Allah selalu memberi petunjuk orang yang dikehendaki-Nya kepada jalan yang lurus.” (Q.S. Al-Baqarah [2]: 213) 
Selain masalah ketinggian derajat para ulama, Al-Quran juga menyebutkan dari sisi mentalitas dan karakteristik, bahwa para ulama adalah orang-orang yang takut kepada Allah. Sebagaimana disebutkan di dalam salah satu ayat:

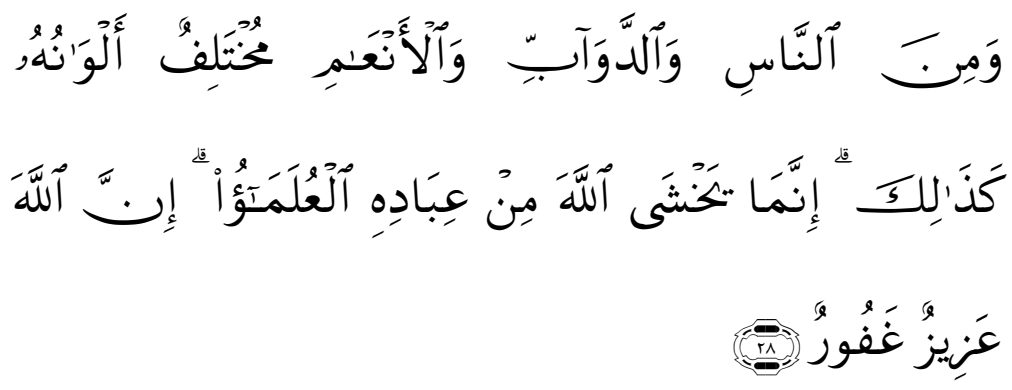

"Dan demikian (pula) di antara manusia, binatangbinatang melata dan binatang-binatang ternak ada yang bermacam-macam warnanya (dan jenisnya). Sesungguhnya yang takut kepada Allah di antara hambahamba-Nya, hanyalah ulama. Sesungguhnya Allah Maha Perkasa lagi Maha Pengampun." (Q.S. Faathir [35]: 28)

Berdasarkan ayat dan hadits di atas, tidaklah merupakan sesuatu yang mustahil jika ulama adalah orang yang sangat tinggi ilmunya utamanya ilmu agama karena ulama adalah pewaris nabi. Dengan ilmu manusia menjadi berbeda dengan 
makhluk lainnya. Al-Ghazali (tt.) berkata: "ilmulah yang membedakan manusia dari binatang, dengan ilmu ia menjadi mulia bukan dengan kekuatan fisiknya sebab dari sisi ini unta jauh lebih kuat, dan bukan kebesaran tubuhnya sebab gajah pasti melebihinya, juga bukan dengan keberaniannya sebab serigala lebih berani darinya. Manusia diciptakan hanya untuk ilmu”.

\section{Rangkuman}

1. Perintah menunut ilmu didasarkan pada beberapa dalil antara lain: Surat al-Mujadilah ayat 11, Surat Taubah ayat 122 , surat al-Alaq ayat 1-5 dan hadits yang diriwayatkan oleh Ibn Majah nomor 220.

2. Keutamaan orang menunut adalah memiliki derajat yang sangat terhormat (Q.S. Al-Mujadilah [58]: 11), dimudahkan jalannya ke surga. Para malaikat akan menghormatinya dengan meletakkan sayap-sayapnya. Seluruh makhluk yang ada di bumi, sampai ikan-ikan yang ada di laut terdalam sekalipun, akan memohonkan ampunan dan mendapatkan jaminan bahwa orang yang berilmu dan ilmunya tersebut bermanfaat bagi orang lain, maka pahalanya akan terus mengalir walau orang yang bersamgkutan telah meninggal dunia.

3. Kedudukan ulama dalam Islam sebagai pewaris para Nabi, yaitu mempunyai tugas sesuai dengan apa yang dikerjakan nabi antara lain: (a) Menyampaikan ajaran kitab suci itu secara baik dan bijaksana dengan tidak mengenal takut dan siap menanggung resiko; (b) Menjelaskan kandungan kitab suci; (c) Membawa kabar gembira, memberi peringatan, 
mengajak kepada Allah dan memberi cahaya; dan (d) Memberi putusan atas problem yang terjadi di masyarakat.

\section{Latihan/Tugas/Eksperimen}

Mengidentifikasi dan menerapkan nilai-nilai keutamaan menuntut ilmu dalam kehidupan sehari-hari, yang meliput: adab penutup ilmu terhadap dirinya sendiri, adab penuntut ilmu terhadap gurunya, adab penuntut ilmu terhadap pelajarannya, dan adab penuntut ilmu terhadap buku sebagai alat ilmiah.

\section{DAFTAR PUSTAKA}

Ahmad, Abu al-Husain ibn Faaris ibn Zakariya. tt. Mu'jam Maqaayid al-Lugah. Bairut: Daar al-Fikr.

Al-Ghazali, Abu Hamid. Ihya 'ulumu diin. Beirut: Dar al Ma'rifah.

Depag RI. 2009. Al-Quran dan Terjemahnya. Jakarta: Yayasan Penyelenggara Penterjemah Al-Quran.

Ghafur, Waryono abdul. 2007. Hidup Bersama al-Quran: Jawaban al-Quran terhadap Problematika Sosial. Yogyakarta: Pustaka Rihlah.

Husaini, Adian. 2013. Filsafat IImu dalam Perspektif Barat dan Islam. Jakarta: Gema Insani.

Jauzi, Ibn. tt. Zad Al-Masir. Beirut: Dar al-Thaibah.

Katsir, Ibn. 2002. Tafsir Al-Qur'an Al-Azhim. Beirut: Dar al-Thaibah. 
Muhammad Ibn Mukrim Ibn Manzur al-Afriqi. tt. Lisan al-'Arab. Bairut: Daar Sadir.

Program CD Kutub Al-Tis'ah. Mausu'ah Al-Hadith Al-Syarif. 


\section{BAB IV}

\section{ETIKA PENGEMBANGAN DAN PENERAPAN IPTEKS DALAM \\ PANDANGAN ISLAM}

\section{A. Pendahuluan}

Ilmu dalam prosesnya telah menciptakan peradaban bagi manusia, mengubah wajah dunia, dan masuk ke setiap lini kehidupan sebagai sarana yang membantu manusia dalam mencapai tujuan hidupnya. Sehingga manusia berhutang banyak terhadap ilmu. Namun, ketika ilmu berbalik menjadi musibah bagi manusia, di saat itulah dipertanyakan kembali untuk apa seharusnya ilmu itu digunakan. Dalam persoalan ini, maka ilmuwan harus kembali pada persoalan nilai dan etika dalam bingkai ilmu agar ilmu tidak bergerak ke arah yang membahayakan.

Mengadapi kenyataan seperti ini, ilmu yang pada hakikatnya mempelajari alam sebagaimana adanya, mulai mempertanyakan untuk apa sebenarnya ilmu itu dipergunakan? Dimana batas wewenang penjelajahan keilmuan dan ke arah mana perkembangan ilmu yang seharusnya. Pertanyaan yang semacam ini jelas tidak metupakan urgensi bagi keilmuan. Namun pada abad ke-20 para ilmuwan mencoba menjawab pertanyaan ini dengan berpaling pada hakikat moral. Penyajian materi bahasan dalam 
bab ini lebih terfokus kepada (1) Sinergi Ilmu dan pengintegrasiannya dengan nilai dan ajaran Islam; (2) Paradigm ilmu tidak bebas nilai dan bebas nilai; dan (3) Perlunya akhlak Islami dalam penerapan IPTEKS.

Berdasarkan penyajian materi tersebut, diharapkan mahasiswa dapat:

1. Melakukan mensinergikan dan mengintegrasikan ilmu dengan ajaran Islam sesuai keilmuan yang dipilihnya.

2. Menjelaskan paradigm ilmu tidak bebas nilai (value bound) dan bebas nilai (value free).

3. Menjadikan etika Islam sebagai landasan utama dalam penerapan IImu Pengetahuan, terutama dalam menjunjung tinggi nilai-nilai kemanusiaan yang bersesuaian dengan fitrah penciptaan manusia.

\section{B. Penyajian Materi}

\section{Sinergi Ilmu dan Pengintegrasiannya dengan Nilai dan}

\section{Ajaran Islam}

Integrasi sinergis antara ajaraan Islam dan ilmu pengetahuan secara konsisten akan menghasilkan sumber daya yang handal dalam mengaplikasikan ilmu yang dimiliki dengan diperkuat oleh spiritualitas yang kokoh dalam menghadapi kehidupan. Islam tidak lagi dianggap sebagai agama yang kolot, melaikan sebuah kebutuhan untuk 
mengaktualisasikan diri di berbagai bidang kehidupan, dan sebagai fasilitas untuk perkembangan ilmu dan teknologi (Turmudi, 2006).

Islam mementingkan pengembangan dan penguasaan Iptek untuk menjadi sarana ibadah-pengabdian Muslim kepada Allah SWT dan mengembang amanat khalifatullah (wakil/mandataris Allah) di muka bumi untuk berkhidmat kepada kemanusiaan dan menyebarkan rahmat bagi seluruh alam (Rahmatan lil 'Alamin). Ada lebih dari 800 ayat dalam AlQur'an yang mementingkan proses perenungan, pemikiran dan pengamatan terhadap berbagai gejala alam, untuk ditafakuri dan menjadi bahan dzikir (ingat) kepada Allah. Dalam pengertian Islam akal bukanlah otak tetapi daya fikir yang terdapat dalam jiwa manusia untuk memperoleh pengetahuan dengan memperhatikan alam sekitar. Dalam Alquran banyak sekali anjuran terhadap umat Islam untuk memnggunakan akal dalam menangkap sinyal keagungan Tuhan. Al-quran selain memiliki dimensi yang normatif juga memiliki dimensi yang menggiring manusia untuk selalu berpikir dengan menggunakan akalnya. Sebagaimana termaktub dalam QS. Al Mujadillah ayat 11: "Allah akan mengangkat derajat orang-orang yang beriman dan berilmu pengetahuan beberapa derajat."

Dalam Al-Qur'an banyak sekali ditemukan idiom-idiom dan anjuran bagi umat Islam untuk berbuat secara empirik- 
praktis dengan cara meneliti, mencari data dari alam sekitar semisal pergantian malam dan siang, proses kehidupan biologis, dan misteri alam semesta. Penggunaan akal dalam Islam tidak hanya bersifat teoritis tetapi telah dipraktekkan dalam sejarah pembangunan peradaban Islam. Sebagaimana firman Allah dalam QS. Al-Alaq ayat 1:

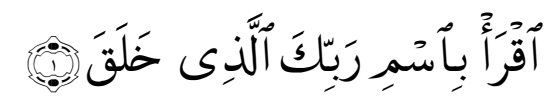

"Bacalah dengan (menyebut) nama Tuhanmu yang Menciptakan." (Q.S. Al-Alaq [96]: 1).

Dari ayat di atas dapat dipahami bahwa umat manusia diperintahkan untuk "membaca". Sebuah perintah yang diidentikkan dengan pengamatan manusia terhadap ayat-ayat Allah, baik secara Qouliyyah ataupun Kauniyah yang pada akhirnya dapat memahami kehendak Tuhan yang termanifestasikan dalam aturan alam. Kegiatan pengamatan inilah, merupakan cikal bakal perenungan manusia untuk menemukan konsep ilmu pengetahuan yang strukturnya dibentuk oleh akal tanpa melupakan Agama.

Kesadaran masa itu dapat kita sebut dengan kesadaran integratif-holistik, artinya tidak ada batas pembeda antara ilmu agama dan ilmu non-agama. Karena dua elemen ini diyakini sebagai sarana untuk menemukan anugerah dan keagungan Tuhan yang menjelma dalam alam ciptaannya. Namun, tentu saja kesadaran itu tidak hanya tumbuh karena 
tekanan sosiologis dan politis semata. Faktor pembentuk yang disadarkan pada motivasi teologis di mana Islam sangat menganjurkan penggunaan akal, juga berperan dalam membangun kesadaran ilmiah tersebut.

Secara aksiologis pengembangan ilmu pengetahuan pada masa kejayaan itu memiliki dua karakteristik. Pertama, kesadaran untuk menjadikan ilmu pengetahuan sebagai pembentuk peradaban. Pengembangan ilmu pengetahuan yang dilakukan oleh umat Islam saat itu diarahkan untuk membangun peradaban yang lebih unggul dari peradaban di sekitarnya. Umat Islam meyakini bahwa Islam tidak hanya berposisi sebagai agama tetapi juga sebagai kebudayaan dan peradaban.

Corak kedua, munculnya kesadaran bahwa semakin umat Islam mempelajari ilmu pengetahun semakin dekat pula ia merasakan keagungan Tuhan. Menurut Sayyed Hossien Nasr bahwa pengembangan ilmu yang dilakukan oleh ulama klasik ini tidak hanya dijiwai oleh jiwa ilmiah tetapi juga untuk menyatakan hikmat pencipta dalam ciptaannya. Motivasi seperti itulah yang membangkitkan ghairah umat Islam dalam mengkaji ilmu pengetahuan yang tidak terkotakkan dengan ilmu agama dan umum (Nasr, 2003). Sebagaimana Firman Allah berikut: 


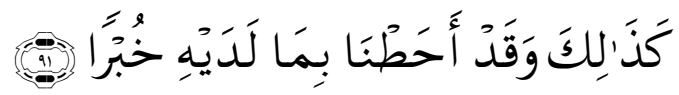

“Demikianlah. dan Sesungguhnya ilmu Kami meliputi segala apa yang ada padanya." (Q.S. Al-Kahfi [18]: 91)

Berdasar dua karekteristik di atas dapat dilihat Islam menempatkan pengembangan sains tidak sebagai pengembangan ilmu murni tetapi sebagai sains instrumental yang menjamin terhadap bangunan kesadaran yang mantap dan kebudayaan yang mapan.

Bagi umat Islam, kedua-duanya adalah merupakan ayatayat (atau tanda-tanda/sinyal) KeMahaKuasaan dan Keagungan Allah SWT. Ayat tanziliyah/naqliyah (yang diturunkan atau transmited knowledge), seperti kitab-kitab suci dan ajaran para Rasulullah (Taurat, Zabur, Injil dan Al Qur'an), maupun ayat-ayat kauniyah (fenomena, prinsipprinsip dan hukum alam), keduanya bila dibaca, dipelajari, diamati dan direnungkan, melalui mata, telinga dan hati (qalbu atau akal) akan semakin mempertebal pengetahuan, pengenalan, keyakinan dan keimanan kepada Allah SWT, Tuhan Yang Maha Kuasa, Wujud yang wajib, Sumber segala sesuatu dan segala eksistensi).

Berdasar fenomena tersebut di atas, ajaran Islam dan ilmu pengetahuan, tidak terlepas satu sama lain. Ajaran Islam dan ilmu pengetahuan adalah dua sisi koin dari satu mata 
uang koin yang sama. Keduanya saling membutuhkan, saling menjelaskan dan saling memperkuat secara sinergis, holistik dan integratif. Pengetahuan yang dilimpahkan kepada manusia, tidak akan bermakna tanpa dilandasi iman yang benar. Iman tanpa ilmu seperti orang buta, sebaliknya ilmu tanpa iman dapat menjadi bumerang yang dapat menghancurkan diri sendiri maupun orang lain.

Oleh karena itu, manusia tidak hanya bisa mengandalkan kecerdasan intelektual sebagai representasi potensi manusia dalam menemukan ilmu pengetahuan dan teknologi, akan tetapi kecerdasan spiritual yang bermanfaat membimbing manusia tetap berada pada jalur yang benar juga menjadi bagian yang sangat penting. Demikian pula dalam praktek kehidupan manusia sering ditemukan seseorang bisa berbuat bodoh atau jahat padahal ia termasuk orang-orang intelek. Sarjana hukum misalnya, melakukan rekayasa hukum dengan cara-cara yang sangat professional sehingga mengetahui celah-celah melakukan pelanggaran hokum. Seorang ahli di bidang ekonomi tetapi paling hebat dalam hal manipulasi dan koruspsi. Seorang yang mengaku paham tentang agama tetapi perilakukan menyimpang dari nilai-nilai agama. Di sejumlah Negara sekuler terjadi kasus bunuh diri missal yang dilakukan oleh sekelompok intelektual, menjadi indicator bahwa ilmu yang dimiliki tidak mampu memecahkan masalah hidupnya. Seorang hakim atau jaksa yang ahli dikenal 
profesional karena keluasan ilmunya, tetapi masih mau menerima suap. Seorang pendidik yang seharusnya menjadi teladan yang melindungi mereka, tetapi masih ada kasus pelecehan seksual terhadap anak didiknya sendiri.

Sejumlah kasus di atas dengan mudah dapat ditemukan di berbagai media, artinya telah menjadi fenomena di masyarakat. Patologi (penyakit) sosial ini akan menjadi tradisi yang habitual (terbiasa) dan sulit untuk diputus mata rantainya jika tidak ada kesadaran untuk melakukan perubahan. Hal ini disebabkan oleh lepasnya iman dan ketaqwaan seseorang dari ilmu sebagai anugerah Allah. Mereka tidak menyadari bahwa Allah membagikan anugerah ilmu kepada manusia agar dapat mensyukurinya dalam bentuk ketundukan (taslim), kepatuhan (ta'at), meghindarkan diri dari maksiat terhadap Allah.

\section{Paradigm Ilmu Tidak Bebas Nilai (Value Bound)}

Sebelum masuk pada pembahasan paradigm ilmu tidak bebas nilai, terlebih dahulu memahami makna nilai yang dimaksud. Nilai merupakan tema baru dalam filsafat aksiologi, cabang filsafat yang mempelajarinya, muncul untuk yang pertamakalinya pada paruh kedua abad ke-19. Adalah benar bahwa telah mengilhami lebih dari pada seorang filsuf, bahkan Plato telah membahasnya secara mendalam dalam karyanya, dan bahwa keindahan, kebaikan, dan kekudusan 
merupakan tema yang penting bagi para pemikir disepanjang zaman. Sementara itu, minat untuk mempelajari keindahan belum hilang sama sekali; keindahan, sebagaimana yang Nampak dewasa ini sebagai salah satu perwujudan dari cara pandang yang khas terhadap dunia, sebuah cara yang disebut dengan nilai (Frondizi, 2001). Dapat disimpulkan bahwa, nilai merupakan suatu tolak ukur kebaikan, keindahan dan kekudusan suatu objek tertentu.

Paradigma ilmu yang tidak bebas nilai (value bound) memandang bahwa ilmu itu selalu terkait dengan nilai dan harus dikembangkan dengan mempertimbangkan aspek nilai. Pengembangan ilmu jelas tidak mungkin bisa terlepas dari nilai-nilai, kepentingan-kepentingan baik politis, ekonomis, sosial, religius, ekologis, dan nilai-nilai yang lainnya.

Filosof yang menganut teori value bound adalah Habermas berpendapat bahwa ilmu, sekalipun ilmu alam tidak mungkin bebas nilai, karena setiap ilmu selau ada kepentingan-kepentingan teknis (Habernas, 1990). Dia juga membedakan ilmu menjadi 3 macam, sesuai kepentingankepentingan masing-masing, yaitu:

a. Pengetahuan yang pertama, berupa ilmu-ilmu alam yang bekerja secara empiris-analitis. IImu ini menyelidiki gejalagejala alam secara empiris dan menyajikan hasil penyelidikan untuk kepentingan-kepentingan manusia. Dari ilmu ini pula disusun teori-teori yang ilmiah agar 
dapat diturunkan pengetahuan-pengetahuan terapan yang besifat teknis. Pengetahuan teknis ini menghasilkan teknologi sebagai upaya manusia untuk mengelola dunia atau alamnya.

b. Pengetahuan yang kedua, berlawanan dengan pengetahuana yang pertama, karena tidak menyelidiki sesuatu dan tidak menghasilkan sesuatu, melainkan memahami manusia sebagai sesamanya, memperlancar hubungan sosial. Aspek kemasyarakatan yang dibicarakan adalah hubungan sosial atau interaksi, sedangkan kepentingan yang dikejar oleh pengetahuana ini adalah pemahaman makna.

c. Pengetahuan yang ketiga, teori kritis, yaitu membongkar penindasan dan mendewasakan manusia pada otonomi dirinya sendiri. Sadar diri amat dipentingkan disini. Aspek sosial yang mendasarinya adalah dominasi kekuasaan dan kepentingan yang dikejar adalah pembebasan atau emansipasi manusia.

Dalam pandangan Habermas (1990) bahwa ilmu sendiri dikonstruksi untuk kepentingan-kepentingan tertentu yakni nilai relasional antara manusia dan alam seperti ilmu pengetahuan alam, manusia dan manusia seperti ilmu sosial, dan nilai penghormatan terhadap manusia. Jika lahirnya ilmu saja terkait dengan nilai, maka ilmu itu sendiri tidak mungkin bekerja lepas dari nilai. Penganut value bound ini bahkan ada 
yang mengatakan bahwa nilai adalah ruhnya ilmu. Jadi, ilmu tanpa nilai diibaratkan seperti tubuh tanpa ruh (mati) yang berarti tidak berguna.

Ilmu yang tidak bebas nilai ini memandang bahwa ilmu itu selalu terkait dengan nilai dan harus di kembangkan dengan mempertimbangkan nilai. Ilmu jelas tidak mungkin bisa terlepas dari nilai-nilai kepentingan-kepentingan baik politik, ekonomi, sosial, keagamaan, lingkungan dan sebagainya.

\section{Paradigm Ilmu Bebas Nilai (Value Free)}

Diskusi tentang apakah ilmu itu netral dalam arti bebas nilai. Khairul Umam menulis, sejak munculnya kembali paham teosentris, ilmuwan rasionalisme yang bersikukuh dalam pendiriannya terus berjuang untuk membebaskan diri dari mitos dan berusaha mengembalikan citra rasionalismenya. Pada zaman modern, semangat tersebut semakin bangkit setelah Rene Descartes (1596-1650) menyampaikan diktumnya yang terkenal cogito ergo sum (aku berpikir, maka aku ada). Dictum ini mengisyaratkan bahwa rasiolah satu-satu pengetahuan, rasiolah sang raja pengetahuan dan ia harus terbebas dari mitos-mitos keagamaan seperti wahyu, Tuhan, credo, nilai, dan lain sebagainya. Masa inilah yang kemudian melahirkan Renaisans (kelahiran kembali) dalam ilmu pengetahuan serta diikuti Aufklarung (pencerahan) yang 
menandakan bangkitnya ilmu pengetahuan dengan prinsip dasar rasionalisme, netralisme, dan bebas nilai (Umam, 2008).

Ilmu bebas nilai dalam bahasa Inggris sering disebut denganvalue free, yang menyatakan bahwa ilmu dan teknologi adalah bersifat otonom (Keraf, 2001). Bebas nilai artinya setiap kegiatan ilmiah harus didasarkan pada hakikat ilmu pengetahuan itu sendiri. Ilmu pengetahuan menolak campur tangan faktor eksternal yang tidak secara hakiki menentukan ilmu pengetahuan itu sendiri. Penganut paradigma ini menginginkan bahwa ilmu harus bersifat netral terhadap nilai-nilai, baik secara ontologis maupun aksiologis (Suriasumantri, 2001).

Situmorang (2012), menyatakan bahwa sekurangkurangnya ada 3 faktor sebagai indikator bahwa ilmu itu bebas nilai, yaitu:

a. Ilmu harus bebas dari pengendalian-pengendalian nilai. Maksudnya adalah bahwa ilmu harus bebas dari pengaruh eksternal seperti faktor ideologis, religious, cultural, dan sosial.

b. Diperlukan adanya kebebasan usaha ilmiah agar otonom ilmu terjamin. Kebebasan di sini menyangkut kemungkinan yang tersedia dan penentuan diri.

c. Penelitian ilmiah tidak luput dari pertimbangan etis yang sering dituding menghambat kemajuan ilmu, karena nilai etis sendiri itu bersifat universal. 
Paradigma ini mengikuti jejak yang dikembangkan oleh Copernicus, Galileo, dan filosof seangkatannya yang netral nilai secara total. Mereka berpendapat bahwa objek ilmu tetap sebagai objek ilmiah yang harus dihadapi sama, baik secara teoritis maupun secara metodologis. Oleh karena itu, ilmuwan tidak boleh membedakan apakah objek yang dihadapi ilmu itu merupakan bahan dari zat-zat kimia atau keseragaman peristiwa alam (uniformity of natural) atau merupakan masalah yang ada hubungannya dengan kemanusiaan. Manusia disamping sebagai subjek peneliti ilmu, juga sebagai objek yang diteliti secara objektif dari luar, tanpa terpengaruh dengan apa yang menjiwainya (Mudlor, 2004).

Penganut pendapat ini ada yang lebih ekstrim menyatakan bahwa gejala-gejala kemasyarakatan sama dengan gejala fisika, yaitu sama-sama bersifat alami. Pengertian-pengertian seperti kehendak, rasa, motif, nilai dan jenis merupakan hal-hal yang berada di luar dunia eksakta yang adanya hanya dalam dunia angan-angan yang tidak patut ditinjau dari segi ilmiah.

Bebas nilai sesungguhnya adalah tuntutan yang ditujukan pada ilmu agar keberadaannya dikembangkan dengan tidak memperhatikan nilai-nilai lain di luar ilmu itu sendiri, artinya tuntutan dasar agar ilmu dikembangkan hanya demi ilmu itu sendiri tanpa pertimbangan politik, agama 
maupun moral (Syafiie, 2004). Jadi, ilmu harus dikembangkan hanya semata-mata berdasarkan pertimbangan ilmiah murni. Agaknya, inilah yang menjadi patokan sekularisme yang bebas nilai. Tokoh sosiologi, Weber menyatakan bahwa ilmu sosial harus bebas nilai, tetapi ilmu-ilmu sosial harus menjadi nilai yang relevan. Weber tidak yakin ketika para ilmuwan sosial melakukan aktivitasnya seperti mengajar dan menulis mengenai bidang ilmu sosial mereka tidak terpengaruh oleh kepentingan tertentu. Nilai-nilai itu harus diimplikasikan oleh bagian-bagian praktis ilmu sosial jika praktik itu mengandung tujuan atau rasional. Tanpa keinginan melayani kepentingan segelintir orang, budaya, maka ilmuawan sosial tidak beralasan mengajarkan atau menuliskan itu semua. Suatu sikap moral yang sedemikian itu tidak mempunyai hubungan objektivitas ilmiah.

Dalam pandangan ilmu yang bebas nilai, eksplorasi alam tanpa batas dapat dibenarkan, karena hal tersebut untuk kepentingan ilmu itu sendiri, yang terkadang hal tersebut dapat merugikan lingkungan. Contoh untuk hal ini adalah teknologi air condition, yang ternyata berpengaruh pada pemansan global dan lubang ozon semakin melebar, tetapi ilmu pembuatan alat pendingin ruangan ini semata untuk pengembangan teknologi itu dengan tanpa memperdulikan dampak yang ditimbulkan pada lingkungan sekitar. Sedangkan seni misalnya, membuat patung-patung manusia telanjang, 
lukisan-lukisan erotis, fotografi yang menonjolkan pornografi dan tarian-tarian tanpa busana sama sekali adalah bukan masalah dan dibenarkan secara ilmu seni sepanjang untuk ekspresi seni itu sendiri. Setidaknya, ada problem nilai ekologis dalam ilmu tersebut tetapi ilmu-ilmu yang bebas nilai demi tujuan untuk ilmu itu sendiri barangkali menganggap kepentingan-kepentingan ekologis tersebut bisa menghambat ilmu.

Dari uraian di atas dapat dikatakan bahwa penganut paradigma value free berpendirian bahwa ilmu tidak terikat oleh nilai, baik dalam proses penemuannya maupun proses penerapannya karena petimbangan-pertimbangan moral atau nilai hanya menghambat pertumbuhan dan perkembangan ilmu.

\section{Perlunya Akhlak Islami Dalam Penerapan IPTEKS}

Al-Qardhawi (1989), mengemukakan terkait dengan pentingnya akhlak Islami dalam pengembangan ilmu, bahwa akhlak Islami yang harus diperhatikan dalam mengembangkan ilmu pengetahuan adalah:

a. Rasa tanggung jawab di hadapan Allah. Rasa tanggung jawab di hadapan Allah, sebab ulama merupakan pewaris para anbiya. Tidak ada pangkat yang lebih tinggi daripada pangkat kenabian dan tidak ada derajat yang ketinggiannya melebihi para pewaris pangkat itu. 
b. Amanat IImiah. Sifat amanah merupakan kemestian iman termasuk ke dalam moralitas ilmu, tak ada iman bagi orang yang tidak memiliki sifat amanah. Dalam memberikan kriteria orang beriman Allah menjelaskan dalam firmanNya sebagai berikut:

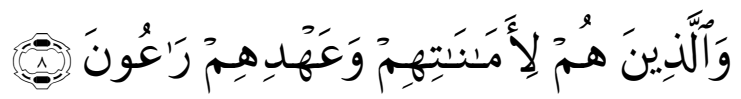

"dan orang-orang yang memelihara amanat-amanat (yang dipikulnya) dan janjinya (Q.S. Al-Mu'minun [23]: 8)

Salah satu dari amanat ilmiah adalah merujuk ucapan kepada orang yang mengucapkanya, merujuk pemikiran kepada pemikirnya, dan tidak mengutip dari orang lain kemudian mengklaim bahwa itu pendapatnya karena hal seperti itu merupakan plagiat dan penipuan. Berkaitan dengan ini dapat disaksikan bahwa ilmuan kaum muslimin sangat memprihatinkan tentang sanad di dalam semua bidang ilmu yang mereka tekuni, bukan hanya dalam bidang hadith saja.

c. Tawadu'. Salah satu moralitas yang harus dimiliki oleh ilmuan ialah tawadu'. Orang yang benar berilmu tidak akan diperalat oleh ketertipuan dan tidak akan diperbudak oleh perasaan 'ujub mengagumi diri sendiri, karena dia yakin bahwa ilmu itu adalah laksana lautan yang tidak bertepi yang tidak ada seorang pun yang akan berhasil mencapai pantainya. 
d. Izzah. Perasaan mulia yang merupakan fadhilah paling spesifik bagi kaum muslimin secara umum. Izzah di sini adalah perasaan diri mulia ketika menghadapi orang-orang yang takabbur atau orang yang berbangga dengan kekayaan, keturunan, kekuatan atau kebanggaankebanggaan lain yang bersifat duniawi. Izzah adalah bangga dengan iman dan bukan dosa dan permusuhan. Suatu perasaan mulia yang bersumber dari Allah dan tidak mengharapkan apapun dari manusia, tidak menjilat kepada orang yang berkuasa.

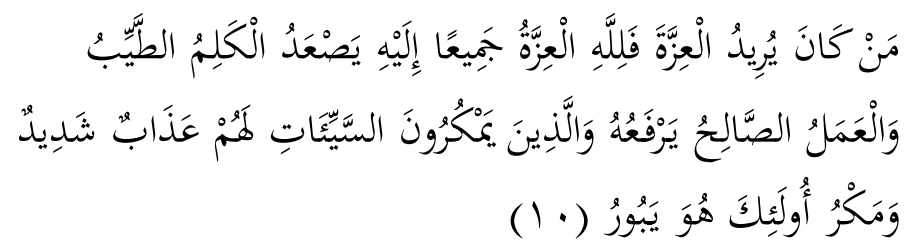

"Barangsiapa yang menghendaki kemuliaan, Maka bagi Allah-lah kemuliaan itu semuanya. KepadaNyalah naik perkataan-perkataan yang baik dan amal yang saleh dinaikkan-Nya. Dan orang-orang yang merencanakan kejahatan bagi mereka azab yang keras. dan rencana jahat mereka akan hancur." (Q.S. Faathir [35]: 10)

e. Mengutamakan dan menerapkan IImu. Salah satu moralitas dalam Islam adalah menerapkan ilmu dalam pengertian bahwa ada keterkaitan antara ilmu dan ibadah. Kehancuran kebanyakan manusia adalah karena mereka 
berilmu, tetapi tidak mengamalkan ilmu itu atau mengamalkan sesuatu yang bertolak belakang dengan apa yang mereka ketahui, seperti dokter yang mengetahui bahayanya suatu makanan atau minuman bagi dirinya tetapi tetap juga dia menikmatinya karena mengikuti hawa nafsu atau tradisi. Seorang moralis yang memandang sesuatu perbuatan tetapi dia sendiri ikut melakukannya dan bergelimang dengan kehinaan itu. Jenis ilmu yang hanya teoritis seperti ini tidak diridhai dalam Islam.

f. Menyebarkan ilmu. Menyebarkan ilmu adalah moralitas yag harus dimiliki oleh para ilmuwan/ulama, mereka berkewajiban agar ilmu tersebar dan bermanfaat bagi masyarakat. Ilmu yang disembunyikan tidak mendatangkan kebaikan, sama halnya dengan harta yang ditimbun. Gugurnya kewajiban menyebarkan ilmu hanya dibatasi jika ilmu yang disebarkan itu akan menimbulkan akibat negatif bagi yang menerimanya atau akan mengakibatkan dampak negatif bagi orang lain atau jika disampaikan akan menimbulkan mudaratnya lebih banyak daripada manfaatnya.

g. Hak Cipta dan Penerbit. Mengenai hak cipta dan penerbit digambarkan bahwa kehidupan para ilmuan tidak semudah kehidupan orang lain pada umumnya, karena menuntut kesungguhan yang khusus melebihi orang lain, seorang ilmuwan pengarang memerlukan perpustakaan 
yang kaya dengan referensi penting dan juga memerlukan pembantu yang menolongnya untuk menukil, mengkliping dan sebagainya dan memerlukan pula orang yang mendapat menopang kehidupan keluarganya.

Tanpa semua itu tidak mungkin seorang pengarang akan menghasilkan suatu karya ilmiah yang berbobot. Di samping itu, jika suatu karya ilmiah telah diterbitkan kadang-kadang pengarang masih memerlukan lagi untuk mengadakan koreksi dan perbaikan-perbaikan, semua ini memerlukan tenaga dan biaya. Oleh karena itu, jika dia sebagai pemilik suatu karya ilmiah maka dialah yang berhak mendapatkan sesuatu berkenan dengan karya ilmiahnya. Tetapi perlu diingat dan dipertegas satu hal, bahwa jangan sampai penerbit dan pengarang mengeksploitasi para pembaca dengan menaikkan harga buku-buku dengan harga yang tidak seimbang dengan daya beli pembaca atau pendapatan yang diperoleh pembaca. Jika terjadi yang demikian maka hal itu tidak dibenarkan oleh syara'

Dari uraian di atas, dapat dilihat betapa pentingnya akhlak Islami bagi pengembangan ilmu, untuk menjaga agar ilmu itu tidak menjadi penyebab bencana bagi kehidupan manusia dan kerusakan lingkungan serta kehancuran di muka bumi ini. Karena tanpa didasari akhlak Islami, maka semakin tinggi ilmu yang mereka dapat, semakin tinggi teknologi yang 
mereka kembangkan, semakin canggih persenjataan yang mereka miliki, semua itu hanya mereka tujukan untuk memuaskan hawa nafsu mereka, tanpa mempertimbangan dengan baik kewajiban mereka terhadap orang lain dan hakhak orang lain.

Berdasar perlunya akhlak Islami di atas, peran Islam menjadi keniscayaan dalam mengembangkan IPTEKS, yaitu di antaranya:

Pertama, menjadikan Aqidah Islam sebagai paradigma ilmu pengetahuan. Paradigma inilah yang seharusnya dimiliki umat Islam, bukan paradigma sekuler seperti yang ada sekarang. Paradigma Islam ini menyatakan bahwa Aqidah Islam wajib dijadikan landasan pemikiran (qaidah fikriyah) bagi seluruh bangunan ilmu pengetahuan. Ini bukan berarti menjadi aqidah Islam sebagai sumber segala macam ilmu pengetahuan, melainkan menjadi standar bagi segala ilmu pengetahuan. Maka ilmu pengetahuan yang sesuai dengan Aqidah Islam dapat diterima dan diamalkan, sedang yang bertentangan dengannya, wajib ditolak dan tidak boleh diamalkan.

Kedua, menjadikan syariah Islam (yang lahir dari aqidah Islam) sebagai standar bagi pemanfaatan iptek dalam kehidupan sehari-hari. Standar atau kriteria inilah yang seharusnya yang digunakan umat Islam, bukan standar manfaat (pragmatism atau utilitarianisme) seperti yang ada 
sekarang. Standar syariah ini mengatur, bahwa boleh tidaknya pemanfaatan iptek, didasarkan pada ketentuan halal-haram (hukum-hukum syariah Islam). Umat Islam boleh memanfaatkan iptek, jika telah dihalalkan oleh Syariah Islam. Sebaliknya jika suatu aspek iptek telah diharamkan oleh Syariah, maka tidak boleh umat Islam memanfaatkannya, walau pun ia menghasilkan manfaat sesaat untuk memenuhi kebutuhan manusia.

\section{Rangkuman}

1. Ilmu tidak bebas nilai, ilmu itu selalu terkait dengan nilainilai. Perkembangan ilmu selalu memperhatikan aspek nilai yang berlaku. Perkembangan nilai tidak lepas dari dari nilainilai ekonomis, sosial, religius, dan nilai-nilai yang lainnya.

2. Ilmu bebas nilai mengemukakan bahwa antara ilmu dan nilai tidak ada kaitannya, keduanya berdiri sendiri. Menurut pandangan ilmu bebas nilai, dengan tujuan mengembangkan ilmu pengetahuan kita boleh mengeksplorasi alam tanpa batas dan tdak harus memikirkan nilai-nilai yang ada, karena nilai hanya akan menghambat perkembangan ilmu.

3. Basis keilmuan tanpa nilai dan tidak dilengkapi oleh aksiologi, etika, religiousitas, dan sosiologi, akan mengakibatkan runtuhnya tatanan sistem kemasyarakatan serta menciptakan tatanan hidup masyarakat yang tidak bertanggungjawab. Kekeringan nilai dalam bingkai ilmu akan berakibat pada runtuhnya ruh ilmu itu sendiri.

4. Pentingnya akhlak Islami bagi pengembangan ilmu, untuk menjaga agar ilmu itu tidak menjadi penyebab bencana bagi 
kehidupan manusia dan kerusakan lingkungan serta kehancuran di muka bumi ini

\section{Latihan/Tugas/Eksperimen}

Mendiskusikan mengintegrasikan etika Islam (Rasa tanggung jawab di hadapan Allah, amanah ilmiah, tawadu', dan menyebarkan ilmu) dalam pengembangan dan penerapan IPTEKS.

\section{DAFTAR PUSTAKA}

Al-Qardhawi, Yusuf. 1989. Metode dan Etika Pengembangan IImu Perspektif Sunnah. Bandung: Rosda.

Frondizi, Risieri. 2001. Pengantar Filsafat Nilai. Yogyakarta: Pustaka Pelajar.

Habermas, Jurgen. 1990. Ilmu Dan Teknologi Sebagai Ideologi. Jakarta: LP3ES.

Keraf, A. Sonny \& Mikhael Dua. 2001. Ilmu Pengetahuan Sebuah Tinjauan Filosofis. Yogyakarta: Kanisius.

Mudlor, Achmad. 2004. Filsafat Ilmu Pengetahuan. Surabaya: Rayyan al-Baihaqi Press.

Nasr, Seyyed Hossein. 2003. Islam : Agama, Sejarah, dan Peradaban. Surabaya: Risalah Gusti.

Situmorang, Joseph MMT. 2012. Ilmu Pengetahuan dan Nilai-nilai, Jakarta: Majalah Filsafat Driyarkara. 
Suriasumantri, Jujun S. 2001. Filsafat IImu; Sebuah Pengantar Populer. Jakarta: Pustaka Sinar Harapan.

Syafiie, Inu Kencana. 2004. Pengantar Filsafat. Bandung: PT Refika Aditama.

Turmudi, dkk. 2006. Islam, Sains dan Teknologi Menggagas Bangunan Keilmuan Fakultas Sains dan Teknologi Islami Masa Depan. Malang: UIN Maliki Press.

Umam, Khairul. 2008. Menyoal Netralitas Sains?

http://www.Khairul.multiply.com. 


\section{BAB V}

\section{INTEGRASI ISLAM DAN ILMU PENGETAHUAN}

\section{A. Pendahuluan}

Al-Qur'an merupakan wahyu dari Allah yang berisi petunjuk bagi manusia. Ajaran-ajarannya disampaikan secara fariatif serta dikemas sedemikian rupa. Ada yang berupa informasi, perintah dan laranagan, dan ada juga yang dimodifikasi dalam bentuk diskripsi kisah-kisah yang mengandung ibrah, yang dikenal dengan istilah ayat-ayat qauliyah dan ayat-ayat kauniyah.

Pada bab ini, membahas ayat-ayat qauliyah dan ayat kauniyah yang Allah berikan kepada manusia secara indrawi atau lewat penelitian dan observasi (al-mubasyiyah) untuk mengungkap gejala-gejala/fenomena kauniyah. Di dalam AlQur'an Allah menjelaskan kekuasaannya dengan contoh-contoh kebenaranya alam ini agar kita semua dapat mengetahui dengan jelas siapa yang menciptakan alam semesta ini dan siapa yang berhak kita sembah semestinya, karena kita sebagai citaanya. Dalam pembahasan ini hanya sedikit akan menjelaskan dan membuktikan bahwa alam semesta ini memang hanya Allah lah yang mencitakan dan agar kita mengetahui apa sebenarnya tujuan Allah menurunkan Al-Quran yang telah banyak memberikan contoh-contoh mengenai alam semesta ini. 
Melalui kajian tentang integrasi Islam dan ilmu pengetahuan pada bab ini diharapkan mahasiswa dapat memahami hakikat ayat-ayat Allah, kesatuan antara ayat qauliyah dan kauniyah serta interkoneksitas dalam memahami ayat qauliyah dan kauniyah.

\section{B. Penyajian Materi}

\section{Hakikat Ayat-Ayat Allah}

Al-Qur'an, mengajak kepada manusia untuk merenungi berbagai kejadian dan benda-benda alam yang dengan jelas menunjukkan kepada keberadaan dan ke-Esaan Allah beserta Sifat-sifat-Nya. Di dalam Al-Qur'an segala sesuatu yang menunjukkan kepada suatu kesaksian (adanya sesuatu yang lain) disebut sebagai "ayat-ayat", yang berarti "bukti yang telah teruji (kebenarannya), pengetahuan mutlak dan pernyataan kebenaran." Jadi ayat-ayat Allah terdiri atas segala sesuatu di alam semesta yang memperlihatkan dan mengkomunikasikan keberadaan dan sifat-sifat Allah. Mereka yang dapat mengamati dan senantiasa ingat akan hal ini akan memahami bahwa seluruh jagad raya hanya tersusun atas ayat-ayat Allah. Hal ini sebagaimana Allah telah menstimulus kepada manusia agar bisa melihat dan mempelajari alam dan seisinya karena dari sanalah Allah menunjukkan kebesaranNya kepada para makhluknya dalam firmanNya berilkut: 


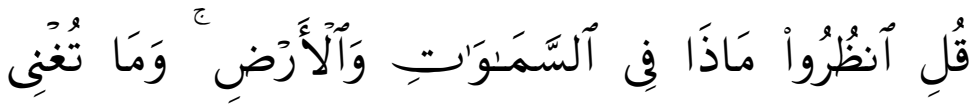

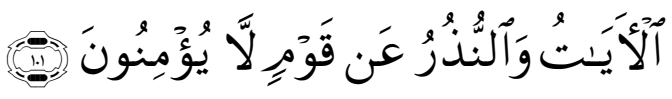

"Katakanlah: "Perhatikanlah apa yang ada di langit dan di bumi. tidaklah bermanfaat tanda kekuasaan Allah dan Rasul-rasul yang memberi peringatan bagi orang-orang yang tidak beriman"." (Q.S. Yunus [10]: 101)

Ayat di atas, mendorong agar manusia mengetahui sifatsifat dan kelakuan alam di sekitarnya, yang akan menjadi tempat tinggal dan sumber bahan serta makanan selama hidupnya. Ayat dalam surat Yunus tersebut di atas menggunakan kata memeriksa dengan nadhor atau intidhor, hal ini dikarenakan tindakan melihat bukanlah sekedar untuk melihat dengan pikiran kosong, melainkan dengan perhatian pada kebesaran dan kekuasaan Allah SWT dan makna yang teramati dari gejala-gejala alam tersebut. Dengan demikian, akan tampak lebih jelas jika kita ikuti teguran-teguran Allah dalam ayat 17-20 Surah al-Ghaasyiyah sebagaimana berikut: 

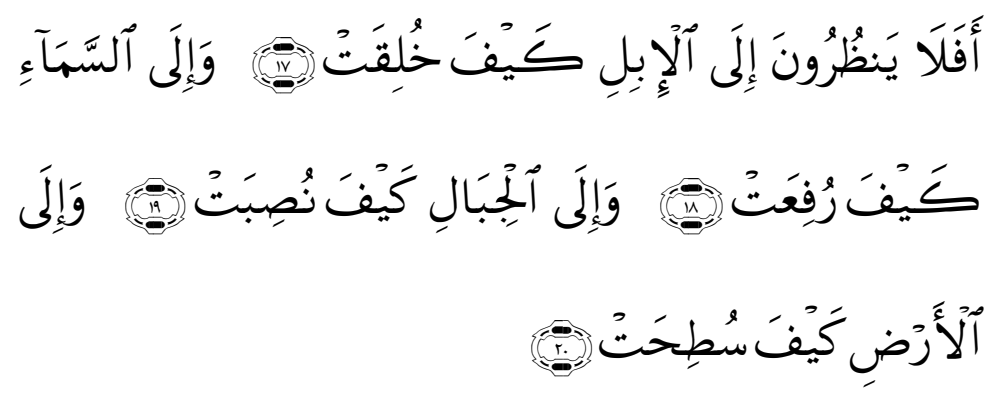

"17. Maka Apakah mereka tidak memperhatikan unta bagaimana Dia diciptakan, 18. dan langit, bagaimana ia ditinggikan? 19 . dan gunung-gunung bagaimana ia ditegakkan? 20. dan bumi bagaimana ia dihamparkan? (Q.S. Al-Ghaasyiyah [88]: 17-20).

Berdasarkan beberapa ayat tersebut di atas, sebenarnya inilah yang dilakukan oleh para pengembang IPTEKS pada umumnya, yaitu melakukan observasi dengan pernuh perhatian untuk dapat jawaban dari pertanyaan "bagaimana proses itu terjadi?". Memeriksa alam semesta dapat diartikan membaca ayat Allah yang dapat merinci dan menguraikan serta menerangkan ayat-ayat dalam al-Qur'an yang merupakan garis besar, sebab dalam kitab suci sendiri alam semesta serta proses yang terjadi di dalamnya sering dinyatakan sebagai ayat Allah.

Dengan demikian, menjadi kewajiban bagi manusia untuk dapat melihat ayat-ayat Allah, mengenal Sang Pencipta yang menciptakannya dan segala sesuatu yang lain, menjadi 
lebih dekat kepada-Nya, menemukan arti keberadaan dan kehidupannya, dan menjadi orang yang beruntung (dunia dan akhirat). Segala sesuatu, nafas manusia, perkembangan politik dan sosial, keserasian kosmik di alam semesta, atom yang merupakan materi terkecil, semuanya adalah ayat-ayat Allah, dan semuanya berjalan di bawah kendali dan pengetahuan-Nya, mentaati hukum-hukum-Nya. Menemukan dan mengenal ayat-ayat Allah memerlukan kerja keras individu. Setiap orang akan menemukan dan memahami ayatayat Allah sesuai dengan tingkat pemahaman dan nalarnya masing-masing.

Beberapa masalah lain yang merupakan perintah Allah SWT agar manusia merenungkannya dalam Al-Qur'an. Ayatayat Allah di alam semesta ditegaskan dalam surat An-Nahl ayat 10-17 :
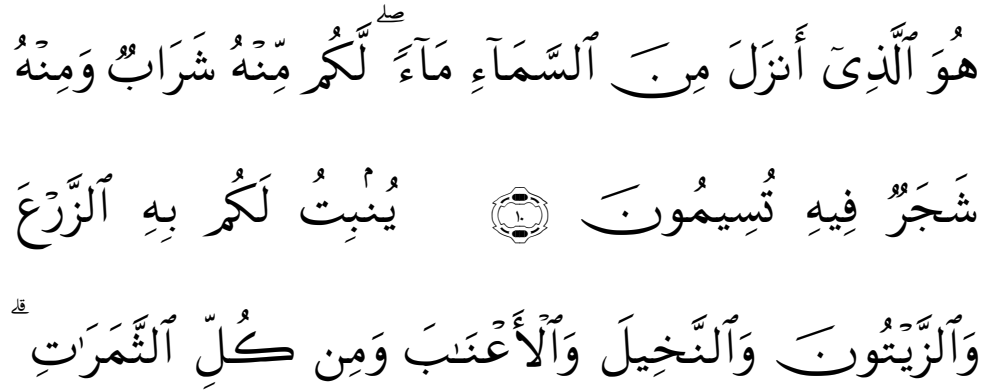

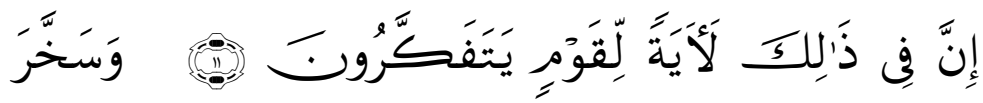




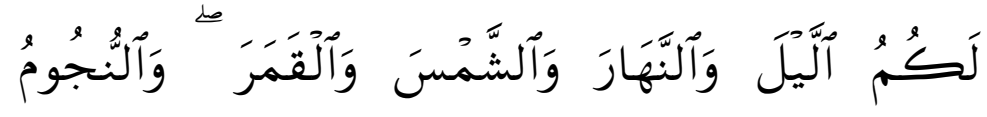

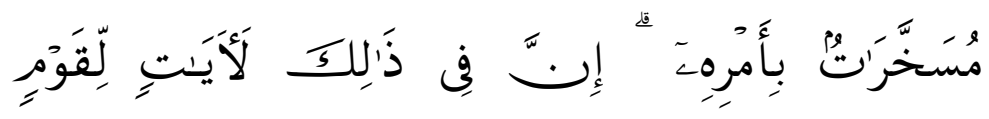

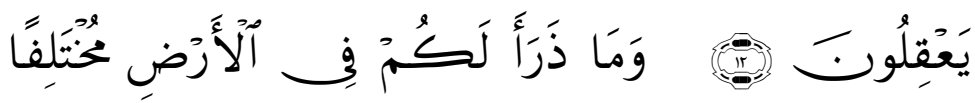

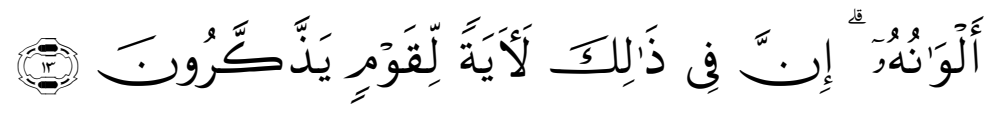

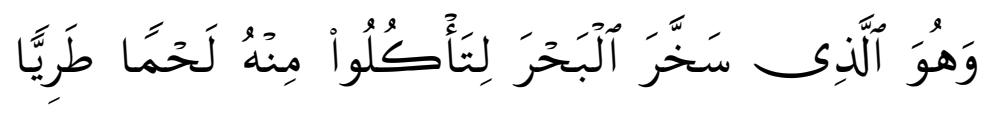

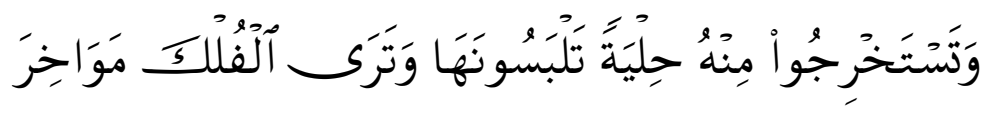

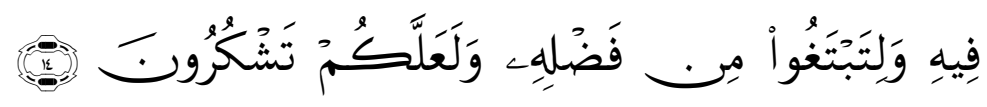

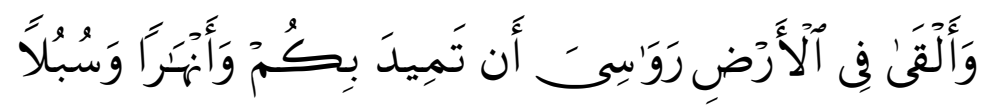

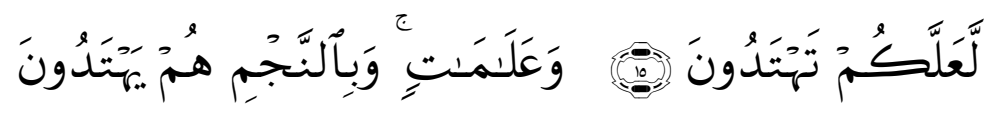

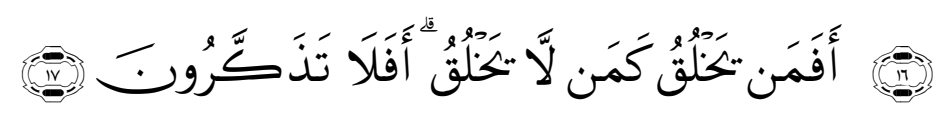

"10. Dia-lah, yang telah menurunkan air hujan dari langit untuk kamu, sebahagiannya menjadi minuman dan sebahagiannya (menyuburkan) tumbuh-tumbuhan, yang pada (tempat tumbuhnya) kamu menggembalakan ternakmu.11. Dia menumbuhkan bagi kamu dengan air hujan 
itu tanam-tanaman; zaitun, korma, anggur dan segala macam buah-buahan. Sesungguhnya pada yang demikian itu benar-benar ada tanda (kekuasaan Allah) bagi kaum yang memikirkan. 12. dan Dia menundukkan malam dan siang, matahari dan bulan untukmu. dan bintang-bintang itu ditundukkan (untukmu) dengan perintah-Nya. Sesungguhnya pada yang demikian itu benar-benar ada tanda-tanda (kekuasaan Allah) bagi kaum yang memahami (Nya), 13. dan Dia (menundukkan pula) apa yang Dia ciptakan untuk kamu di bumi ini dengan berlain-lainan macamnya. Sesungguhnya pada yang demikian itu benar-benar terdapat tanda (kekuasaan Allah) bagi kaum yang mengambil pelajaran. 14. dan Dia-lah, Allah yang menundukkan lautan (untukmu), agar kamu dapat memakan daripadanya daging yang segar (ikan), dan kamu mengeluarkan dari lautan itu perhiasan yang kamu pakai; dan kamu melihat bahtera berlayar padanya, dan supaya kamu mencari (keuntungan) dari karunia-Nya, dan supaya kamu bersyukur. 15. dan Dia menancapkan gununggunung di bumi supaya bumi itu tidak goncang bersama kamu, (dan Dia menciptakan) sungai-sungai dan jalan-jalan agar kamu mendapat petunjuk, 16. dan (dia ciptakan) tandatanda (penunjuk jalan). dan dengan bintang-bintang Itulah mereka mendapat petunjuk. 17. Maka Apakah (Allah) yang menciptakan itu sama dengan yang tidak dapat menciptakan (apa-apa) ?. Maka mengapa kamu tidak mengambil pelajaran." (Q.S. An-Nahl [16]: 10-17).

Beradasarkan ayat Al-Qur'an tersebut di atas, Allah SWT mengajak orang-orang yang berakal agar memikirkan hal-hal yang biasa diabaikan orang lain, atau yang biasa dikatakan sebagai hasil "evolusi", "kebetulan", atau "keajaiban alam" 
belaka. Sebagaimana kita lihat dalam ayat tersebut, orangorang yang berakal melihat ayat-ayat Allah dan berusaha untuk memahami ilmu, kekuasaan dan kreasi seni-Nya yang tak terhingga dengan mengingat dan merenungkan hal-hal tersebut, sebab ilmu Allah tak terbatas, dan ciptaan-Nya sempurna tanpa cacat. Bagi orang yang berakal, segala sesuatu di sekeliling mereka adalah ayat-ayat (tanda-tanda) penciptaan oleh Allah SWT.

Dengan demikian, keberhasilan suatu teknologi bergantung pada kemampuan manusia untuk memilih kondisi yang mendorong alam untuk bertindak seperti yang diinginkannya; dan sudah barang tentu tingkah laku alam dikendalikan oleh sunnatullah yang mengatur bagaimana alam harus berkelakuan pada kondisi tersebut, karena ia tidak dapat berbuat lain. Hal ini Allah berfirman berikut:

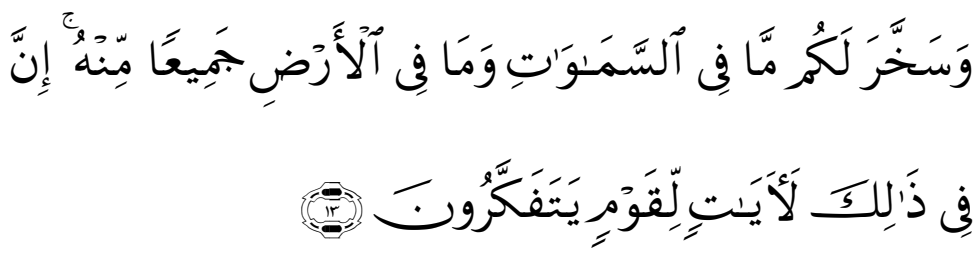

"dan Dia telah menundukkan untukmu apa yang di langit dan apa yang di bumi semuanya, (sebagai rahmat) daripadaNya. Sesungguhnya pada yang demikian itu benar-benar terdapat tanda-tanda (kekuasaan Allah) bagi kaum yang berfikir." (Q.S. Al-Jaatziyah [45]: 13) 
Ayat tersebut di atas, menyatakan bahwa seluruh isi langit dan bumi akan ditundukkan al khaliq bagi umat manusia dengan sains yang diterapkan dengan teknologi yang akan diberikan kepada mereka yang mau melibatkan akalnya dengan menggunakan pikirannya. Penalaran tentang "bagaimana" dan "mengapa", yang menyangkut prosesproses dilangit itu, menyebabkan timbulnya cabang baru dalam sains yang dinamakan astro-fisika, yang bersama-sama dengan astronomi membentuk konsep-konsep kosmologi. Meskipun ilmu pengetahuan kealaman ini tumbuh sebagai akibat dari pelaksanaan salah satu perintah agama kita, kiranya perlu kita pertanyakan apakah benar konsep kosmologi yang berkembang dalam sains itu sama dengan yang terdapat dalam al-Qur'an. Sebab obor sains telah beralih kepada para cendekiawan non Muslim sejak pertengahan abad ke-XIII sampai selesai dalam abad ke-XVII, sehingga sejak itu sains tumbuh dalam kerangka acuan budaya, mental dan spiritual yang bukan Islam, yang memiliki nilai-nilai tidak Islami (Baiquni, 1996).

\section{Kesatuan antara Ayat Qauliyah dan Kauniyah}

Allah SWT menurunkan ayat-ayat (tanda kekuasaan)-Nya melalui 2 jalur formal, yaitu ayat qauliyah dan jalur nonformal yaitu ayat kauniyah. Ayat qauliyah adalah kalam Allah (Al-Qur'an) yang diturunkan secara formal kepad Nabi 
Muhammad SAW. Sedangkan ayat kauniyah adalah fenomena alam, jalurnya tidak formal dan manusia mengeksplorasi sendiri. Al-Quran Al-Karim, yang terdiri dari 6.236 ayat itu, menguraikan berbagai persoalan hidup dan kehidupan, antara lain menyangkut alam raya dan fenomenanya. Uraian-uraian sekitar persoalan sering tersebut sering di sebut ayat-ayat kauniyah.

Secara sederhana, proses terbentuk ilmu pengetahuan menurut Islam sebagai anugerah Allah kepada manusia, dapat digambarkan dalam bagan berikut:

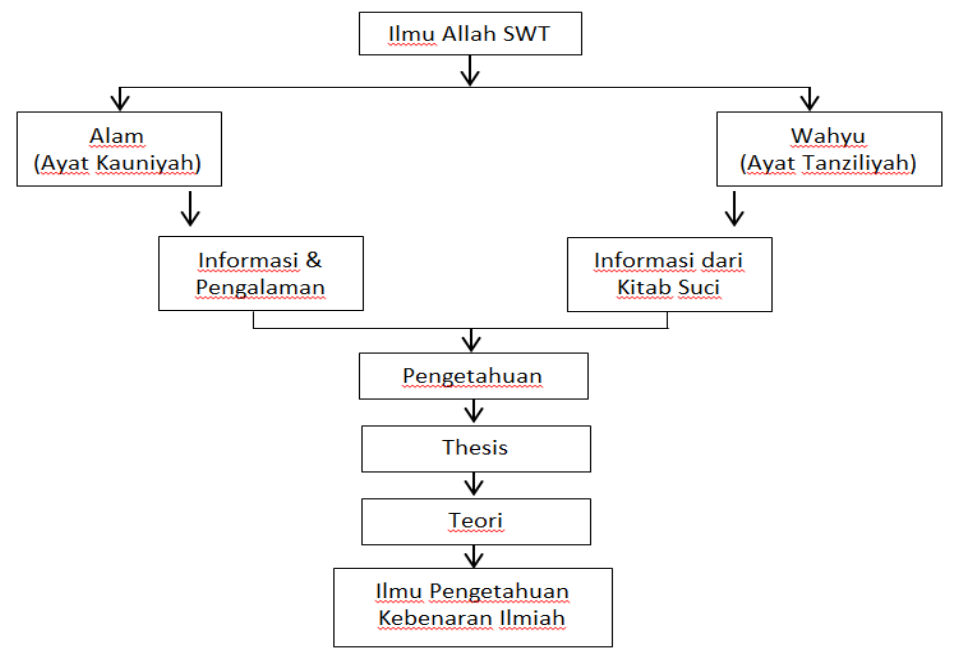

Gambar 5.1 Proses Pembentukan Ilmu Pengetahuan Menurut Al-Qur'an (Sumber: Kaelany, 1992). 
Berdasarkan bagan proses pembentukan ilmu pengetahuan tersebut di atas, bahwa ilmu pengetahuan yang dirumuskan berdasarkan pengetahuan yang dihasilkan oleh pengalaman merupakan kebenaran alami yang merupakan ketentuan Allah atau sunnatullah (ayat kauniyah). Sedangkan yang berasal dari informasi wahyu merupakan bukti kebenaran yang diturunkan Allah kepada para Rasul-Nya dalam bentuk wahyu (ayat tanziliyah).

Proses terbentuknya ilmu pengetahuan tersebut menunjukkan, bahwa Islam tidak mengenal istilah dikotomi, memisahkan dan membedakan antara ilmu kelslaman dan ilmu keduniawian. Sekalipun kebenaran yang terdapat dalam ilmu pengetahuan berupa kebenaran ilmiah, tetapi karena sebenarnya berasal dari Allah SWT juga, maka ilmu pengetahuan dengan wahyu tidak mungkin berlawanan (Kaelany, 1992).

Paradigma seorang muslim terhadap ayat-ayat Allah ini, baik ayat qauliyah (Al-Qur'an) maupun kauniyah (fenomena alam) adalah mutlak benar dan tidak mungkin bertentangan, karena keduanya berasal dari Allah. Pada faktanya sains yang telah "proven" (qath'i) selaras dengan Al-Qur'an seperti tentang peredaran bintang, matahari dan bumi pada orbitnya. Namun sains yang masih dzanni (teori) kadang 
bertentangan dengan yang termaktub dalam Al-Qur'an seperti teori evolusi pada manusia.

Dengan demikian, Allah SWT menuangkan sebagian kecil dari ilmu-Nya kepada umat manusia dengan dua jalan. Pertama, dengan ath-thariqah ar-rasmiyah (jalan resmi) yaitu dalam jalur wahyu melalui perantaraan malaikat Jibril kepada Rasul-Nya, yang disebut juga dengan ayat-ayat qauliyah atau tanziliyah. Kedua, dengan ath-thariqah ghairu rasmiyah (jalan tidak resmi) yaitu melalui ilham secara kepada makhluk-Nya di alam semesta ini (baik makhluk hidup maupun yang mati), tanpa melalui perantaraan malaikat Jibril. Karena tak melalui perantaraan malaikat Jibril, maka bisa disebut jalan langsung (mubasyaratan). Kemudian jalan ini disebut juga dengan ayatayat kauniyah.

Ayat-ayat qauliyah mengisyaratkan kepada manusia untuk mencari ilmu alam semesta (ayat-ayat kauniyah), oleh sebab itu manusia harus berusaha membacanya, mempelajari, menyelidiki dan merenungkannya, untuk kemudian mengambil kesimpulan. Allah SWT. berfirman: 


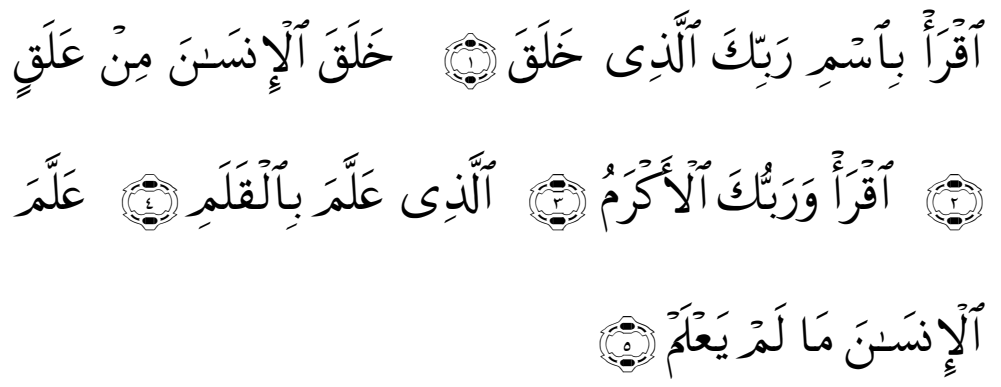

"1. bacalah dengan (menyebut) nama Tuhanmu yang Menciptakan, 2. Dia telah menciptakan manusia dari segumpal darah. 3. Bacalah, dan Tuhanmulah yang Maha pemurah, 4. yang mengajar (manusia) dengan perantaran kalam, 5. Dia mengajar kepada manusia apa yang tidak diketahuinya." (Q.S. Al-Alaq [96]: 1-5)

Dalam konsep Ibrahim (2005), bahwa perintah membaca ini harus diterjemahkan sebagai membaca dalam arti luas dan tidak hanya terhadap objek yang tertulis (ayat qur'aniyah), tetapi juga pada objek yang tercipta semesta (ayat kauniyah). Dengan menghayati secara seksama model yang tercipta ini diharapkan dapat menangkap pesan yang tersirat dari fenomena alam yang ada (Kaelany, 1992). Selanjutnya Kaelany mengatakan bahwa implikasi dari perintah membaca itu merangsang manusia untuk giat menulis, meneliti, mengobservasi, menganalisis dan kemudian merumuskannya sebagai teori ilmu. 


\section{Interkoneksitas dalam Memahami Ayat Qauliyah dan}

\section{Kauniyah}

Secara garis besar, Allah menciptakan ayat dalam dua jalan keduanya saling menegaskan dan saling terkait satu sama lainnya. Hal ini membuktikan bahwa kemampuan manusia untuk memaham keduanya adalah keniscayaan. Allah tidak hanya memberikan perintah untuk sekedar memahami ayat-ayat Allah berupa Qauliyah, tetapi juga untuk melihat fenomena alam ini.

Alam adalah ayat Allah SWT yang tidak tertuang dalam bentuk perkataan Allah untuk dibaca dan dihafal. Tetapi alam adalah ayat Allah yang semestinya dieksplor dan digali sedalam-dalamnya untuk semakin manusia mendekatkan diri pada kemahakuasaan Allah SWT. Bentuk interkoneksitas antara ayat kauniyah dengan ayat qauliyah didasarkan pada Firman Allah berikut:

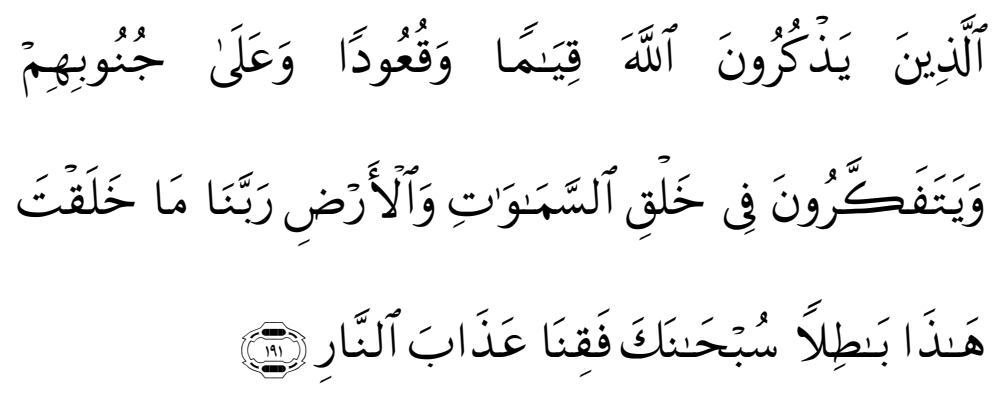


"(yaitu) orang-orang yang mengingat Allah sambil berdiri atau duduk atau dalam keadan berbaring dan mereka memikirkan tentang penciptaan langit dan bumi (seraya berkata): "Ya Tuhan Kami, Tiadalah Engkau menciptakan ini dengan sia-sia, Maha suci Engkau, Maka peliharalah Kami dari siksa neraka.” (Q.S. Ali 'Inran [3]: 191)

Berdasarkan ayat di atas, dalam pandangan seorang muslim ayat qauliyah akan memberikan petunjuk/isyarat bagi kebenaran ayat kauniyah, misalnya surat An-Nur [24]: 43 mengisyaratkan terjadinya hujan, surat Al-Mukminun [23]: 12-14 mengisyaratkan tentang keseimbangan dan kesetabilan pada sistem tata surya, surat Al-Ankabut [29]: 20 mengisyaratkan adanya evolusi pada penciptaan makhluk di bumi, surat Az-Zumar [39]: 5 dan surat an-Naml [27]: 28 mengisyaratkan adanya rotasi bumi dan bulatnya bumi, sebaliknya ayat kauniyah akan menjadi bukti (Al-Burhan) bagi kebenaran ayat qauliyah (lihat surat Al-Fushshilat [41]: 53).

Beberapa contoh lain bentuk interkoneksitas ayat qauliyah dan kauniyah ditunjukkan pada hasil observasi dan penelitian yang berulang-ulang bahwa "siklus hidrologi" atau sikulasi air (hydrologi cycle) dapat dijelaskan sebagai berikut:

Siklus hidrologi adalah sirkulasi air yang terjadi akibat radiasi/panas matahari, sehingga air yang dilaut, sungai, dan juga air pada tumbuh-tumbuhan mengalami penguapan ke 
udara (transpiration), sehingga dikenal sebagai evapotranspiration, lalu uapair tersebut pada ketinggian tertentu menjadi dinggin dan terkondensasi menjadi awan. Akibat angin, bekumpulan awan dengan ukuran tertentu dan terbuat awan hujan, karena pengaruh berat dan gravitasi kemudian terjadilah hujan (presipitasion). Beberapa air hujan ada yang mengalir di atas permukaan. Tanah sebagai aliran limpasan (overland flow) dan ada yang terserap kedalam tanah (infiltrasioan). Aliran limpasan selanjutnya dapat mengisi tampungan-cekungan (depresioan storage). Apabila tampungan ini telah terpenuhi, air akan menjadi limpasanpermukaan (surface runoff) yang selanjutnya mengalir kelaut. Sedangkan air yang terinfiltrasi, bisa keadaan formasi geologi memungkinkan, sebagian dapat mengalir literal di lapisan tidak kenyang air sebagai aliran antara (subsurface flow/interflow). Sebagian yang lain mengalir vertikal yang disebut dengan "perkolasi" (percolation) yang akan mencapai lapisan kenyang air (saturated zone/aquifer). Air dalam akifer akan mengalir sebagai air tanah (grounwter flow/base flow) kesungai atau ketampungan dalm (deep storage). Siklus hirologi ini terjadi terus-menerus atau berulang-ulang dan tidak terputus.

Ayat kauliyah pada penjelasan fenomena kauliyah, dapat kita tarik kesimpulan bahwa "siklus hidrologi" memiliki 4 
(empat) macam proses yang saling menguatkan, yaitu: (a) hujan/presipitasi; (b) penguapan/evaporasi; (c) infiltrasi dan perkolasi (peresapan); dan (d) lipahan permukaan (surface runoff) dan limpasan iar tanah (subsurface rzrnoff). Isyarat adanya fenomena "siklus hidrologi" dapat kata lihat pada firman Allah SWT berikut:

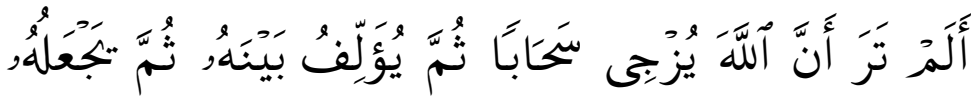

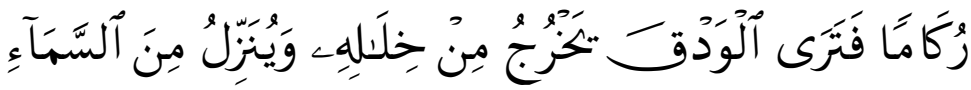

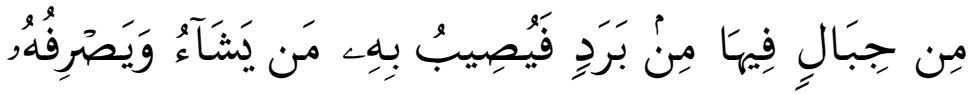

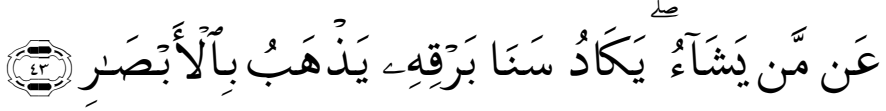

"Tidaklah kamu melihat bahwa Allah mengarak awan, kemudian mengumpulkan antara (bagian-bagian)nya, kemudian menjadikannya bertindih-tindih, Maka kelihatanlah olehmu hujan keluar dari celah-celahnya dan Allah (juga) menurunkan (butiran-butiran) es dari langit, (yaitu) dari (gumpalan-gumpalan awan seperti) gunung-gunung, Maka ditimpakan-Nya (butiran-butiran) es itu kepada siapa yang dikehendaki-Nya dan dipalingkan-Nya dari siapa yang dikehendaki-Nya. Kilauan kilat awan itu Hampir-hampir menghilangkan penglihatan." (Q.S. An-Nuur [24]: 43) 
Pada ayat di atas, menunjukkan adanya proses inti yang sedang berlangsung dan merupakan bagian dari proses "siklus hidrologi." Kedua proses itu, yaitu proses penguapan (evaparasi) yang ditunjukkan dengan kata "awan" dan proses hujan (presipitasi) yang berupa keluarnya air dan butiran es dari awan. Di mana awan adalah massa uap air yang terkumpul akibat penguapan dan kondisi atmosfir tertentu.

Menurut Harto (2000) seorang pakar biologi, awan dalam keadan ini yang kalau masih mempunyai butir-butir air berdiameter lebih kecil dari $1 \mathrm{~mm}$ masih akan melayanglayang di udara karena berat butir-butir tersebut masih lebih kecil daripada gaya tekan ke atas udara. Sehingga pada kondisi ini awan masih bisa bergerak terbawa angin, kemudian berkumpul menjadi banyak dan bertindih-tindih (bercampur), dalam ayat lain awan menjadi bergumpalgumpal seperti pada firman Allah berikut:

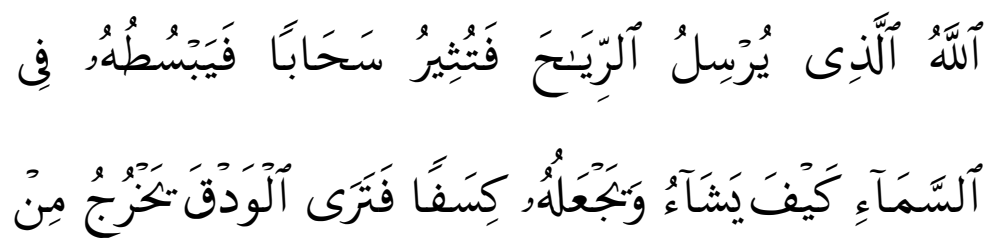



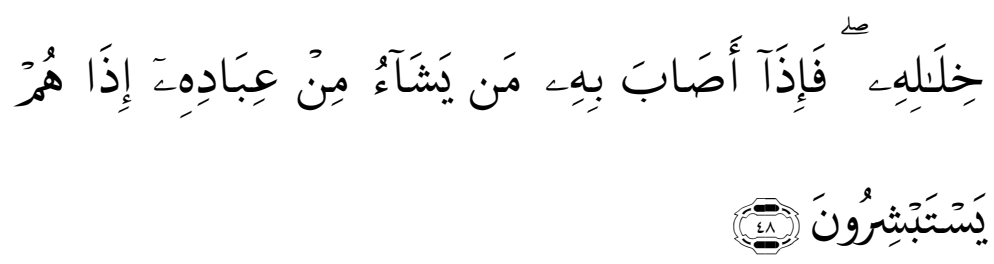

"Allah, Dialah yang mengirim angin, lalu angin itu menggerakkan awan dan Allah membentangkannya di langit menurut yang dikehendaki-Nya, dan menjadikannya bergumpal-gumpal; lalu kamu Lihat hujan keluar dari celah-celahnya, Maka apabila hujan itu turun mengenai hamba-hamba-Nya yang dikehendakiNya, tiba-tiba mereka menjadi gembira." (Q.S. Ar-Ruum [30]: 48)

Demikian jelaslah bahwa dengan terbawanya awan oleh pergerakkan angin, maka awan akan berkumpul menjadi banyak dan bergumpal-gumpal. Akibat berbagai sebab klimatologis seperti pengaruh kondensasi, awan tersebut dapat menjadi awan yang potensial menimbulkan hujan, yang biasanyamnurut Harto (2000) terjadi bila butir-butir berdiameter lebih besar dari pada $1 \mathrm{~mm}$.

Sehingga pada ayat di atas "hujan keluar dari celahcelahnya" awan, maksudnya secara ilmiah "hujan" turun tidak seperti menggelontornya air, melainkan berupa butir-butir air kecil (lebih besar dari pada $1 \mathrm{~mm}$ )yang turun dari awan akibat 
pengaruh berat dan gravitasi bumi, seperti jatuhnya tetestetes aur dari celah-celah mata air. Sedangkan turunya butiran-butiran es langit, itu disebabkan apabila gumpalangumpalan awan pada ketinggian tertentu dan kondisi atmosfir tertentu mengalami kondensasi sampai mencapai kondisi titik beku, sehingga terbentuklah gunung-gunung es. Kemudian karena pengaruh berat dan gravitasi bumi sehingga jatuh/turun ke permukaan bumi, dan dalam perjalananya dipengaruhi oleh temperatur, pergerakan angin dan gesekan lapisan udara, maka gunung es itu peceh menjadi butir-butir es yang jatuh ke permukaan bumi. Bila terjadi hujan masih besar kemungkinan air teruapkan kembali sebelum sampai di permukaan bumi, karena keadaan atmosfir tertentu. Hujan baru dusebut sebagai hujan apabila telah sampai di permukaan bumi dapat diukur. Air hujan yang jatuh di permukaan bumi terbagi menjadi 2 bagian, yaitu sebagai air lintasan dan sebagai air yang terinflocrsi/meresap ke dalam tanah (Harto. 2000). Kaidah-kaidah atas di tunjukkan pula pada surat Al-Mukminun ayat 18 berikut:

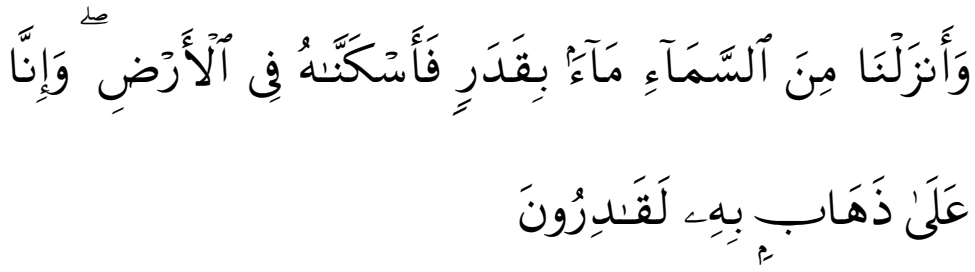


"dan Kami turunkan air dari langit menurut suatu ukuran; lalu Kami jadikan air itu menetap di bumi, dan Sesungguhnya Kami benar-benar berkuasa menghilangkannya." (Q.S. Al-Mukminun [23]: 18)

Pada ayat di atas Allah menurunkan hujan menurut suatu ukuran sehingga hujan yang sampai di permukaan bumi dapat diukur. Hanya tinggal kemampuan manusai sampai di mana tingkat validitasnya dalam mengukur dan memperkirakan jumlah atau kuantitas hujan. Sehingga timbul beberapa teori pendekatan dalam analisis kuantitas hujan yang menjadikan berkembangnya ilmu hidrologi. "Lalu Kami jadikan air itu menetap di bumi". Maksudnya adalah air yang jatuh dari langit itu tinggal di bumi menjadi sumber air, sebagai mana tercantum dalam surat Az-Zumar ayat 21 berikut:
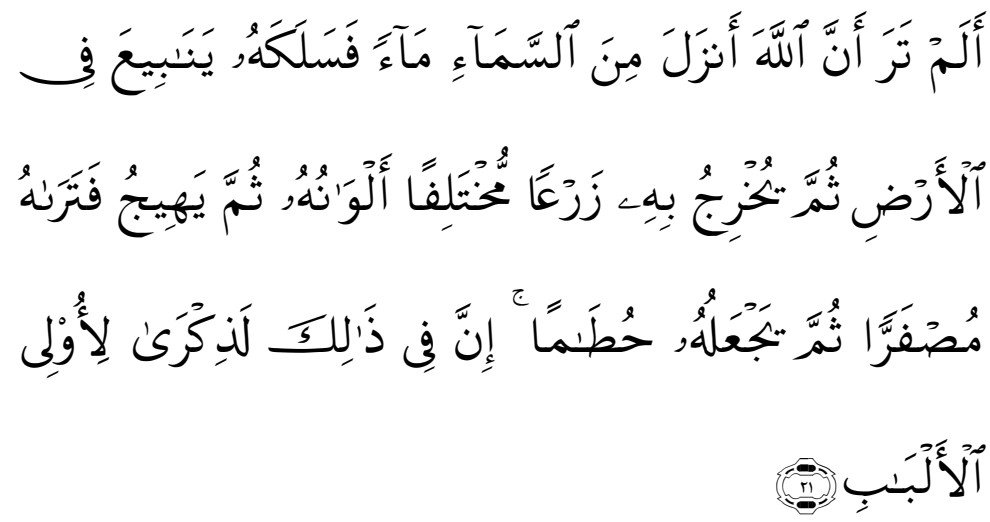
"Apakah kamu tidak memperhatikan, bahwa Sesungguhnya Allah menurunkan air dari langit, Maka diaturnya menjadi sumber-sumber air di bumi kemudian ditumbuhkan-Nya dengan air itu tanam-tanaman yang bermacam-macam warnanya, lalu menjadi kering lalu kamu melihatnya kekuning-kuningan, kemudian dijadikan-Nya hancur berderai-derai. Sesungguhnya pada yang demikian itu benar-benar terdapat pelajaran bagi orang-orang yang mempunyai akal." (Q.S. Az-Zumar [39]: 21).

Kaidah-kaidah seperti ini sebagai mana telah digambarkan pada surat Az-Zumar [39] ayat 21 tersebut di atas dapat dijelaskan bahwa sumber-sumber air di bumi bisa berupa air sebagai aliran limpasan seperti air sungai, danau, dan laut. Juga bisa berupa air tanah (graund water) segagai akibat dari infiltrasi seperti air sumur, air artesi dan sungai bawah tanah. Kata "dan sesungguhnya kami benar-benar berkuasa menghilangkannya" maksudnya Allah berkuasa untuk menghilangkan sumber-sumber air tadi, seperti dengan cara kemarau panjang (akibat siklus musim yang dipengaruhi oleh pergerakan matahari disekitar equator), sehinga tidak ada suplai air sebagai pengisian (recharge ke dalam permukaan tanah atau bawah permukaan tanah. Sedangkan, proses pengguapan, pergerakan air permukaan dan pergerakan air tanah berlangsung terus-menerus, sehingga 
lapisan air tanah (water table) menjadi turun dan sumber mata iar menjadi berkurang, bahkan lebih drastis lagi muka air tanah bisa turun mencapai lapisan akifer artetis yang kedap iar. Maka kondisi seprti itu seringkali terlihat sungaisungai kekeringan, sumur-sumur air dangkal kekeringan, muka air danau surut dan bahkan ada yang sampai kering, dan pohon-pohon mengalami kerontokan dan mati kekeringan.

Dengan demikian, interkoneksitas antara ayat Qauliyah sebagai petunjuk wahyu yang memberikan isyarat global tentang fenomena iptek, untuk membantu menjelaskan dan mencocokkan terhadap ayat kauniyah. hal ini merupakan suatu sunnatullah yang terus menerus tidak terputus.

\section{Rangkuman}

Ayat qauliyah adalah kalam Allah (Al Qur'an) yang diturunkan secara formal kepada Nabi Muhammad SAW. Sedangkan ayat kauniyah adalah fenomena alam, jalurnya tidak formal dan manusia mengeksplorasi sendiri. Ayat-ayat qauliyah mengisyaratkan kepada manusia untuk mencari ilmu alam semesta (ayat-ayat kauniyah), oleh sebab itu manusia harus berusaha membacanya, mempelajari, menyelidiki dan merenungkannya, untuk kemudian mengambil kesimpulan. Dalam bericara tentang alam dan fenomenanya. Paling sedikit ada dua hal yang dapat dikemukakan menyangkut hal tersebut: 
1. Al-Quran memerintahkan atau menganjurkan kepada manusia untuk memperhatikan dan mempelajari alam raya dalam rangka memperoleh manfaat dan kemudahankemudahan bagi kehidupannya dan mengantarkan kepada kesadaran-kesadaran akan keesaan dan kemahakuasaan Allah SWT.

2. Alam dan segala isinya beserta hukum-hukum yang mengaturnya, diciptakan, dimiliki, dan di bawah kekuasaan Allah SWTserta diatur dengan sangat teliti.

Interkoneksitas antara ayat Qauliyah sebagai petunjuk wahyu yang memberikan isyarat global tentang fenomena iptek, untuk membantu menjelaskan dan mencocokkan terhadap ayat Kauniyah.

\section{Latihan/Tugas/Eksperimen}

Mengidentifikasi dan mendiskusikan secara kelompok terhadap koneksitas ayat-ayat qauliyah dengan ayat-ayat kauniyah

\section{DAFTA PUSTAKA}

Al-Quran terjemahnya. 1998. Semarang: Asy-Syifa.

Baiquni, Achmad. 1996. Al-Qur'an dan Ilmu Pengetahuan Kealaman. Jakarta: Dana Bhakti Primayasa.

Harto, Sri. 2000. Hidrologi Teori Masalah Penyelesaian. Jakarta: Nafiri. 
Ibrahim, M., Jasin, M., dan Hidayat, M.T. 2005. Ilmu Alamiah Dasar. Jakarta: RajaGrafindo Persada.

Kaelany HD. 1992. Islam dan Aspek-Aspek Kemasyarakatan. Jakarta: Bumi Aksara.

Yusuf Qardhawi. 1998. Al-Quran Berbicara Tentang Akal Dan IImu Pengetahuan, (terj). Abdul Hayyie Al-Kattani. Jakarta: Gema Isani. 


\section{BAB VI}

\section{PARADIGMA PENGEMBANGAN IPTEKS}

\section{A. Pendahuluan}

Secara garis besar, berdasarkan tinjauan ideologi terdapat 3 (tiga) jenis paradigma pengembangan IPTEKS, yaitu: Paradigma sekuler, sosialis dan Islam. Paradigma sekuler memandang agama dan IPTEK tidak bisa mencampuri dan mengintervensi yang lainnya. Paradigma sosialis, yaitu paradigma dari ideologi sosialisme yang menafikan eksistensi agama sama sekali. Agama itu tidak ada, tidak ada hubungan dan kaitan apa pun dengan IPTEKS. IPTEKS bisa berjalan secara independen dan lepas secara total dari agama. Paradigma ini mirip dengan paradigma sekuler di atas, tapi lebih ekstrem. Paradigma Islam memandang bahwa agama adalah dasar dan pengatur kehidupan. Aqidah Islam menjadi basis dari segala ilmu pengetahuan. Aqidah Islam yang terwujud dalam apa-apa yang ada dalam al-Qur`an dan al-Hadits-menjadi qaidah fikriyah (landasan pemikiran), yaitu suatu asas yang di atasnya dibangun seluruh bangunan pemikiran dan ilmu pengetahuan manusia.

Kajian paradigma pengembangan IPTEKS pada bab ini difokuskan pada dua pembahasan, yaitu potensi manusia dalam 
pengembangan IPTEKS dan rambu-rambu pengembangan IPTEKS dalam Islam. Oleh karena, setelah mempelajari materi ini, diharapkan mahasiswa dapat: (1) memahami potensi akal, hati dan jasadiyah (pancaindra) dalam pengembangan IPTEKS; dan (2) memahami rambu-rambu dalam pengembangan IPTEKS yangf sesuai dengan ajaran Islam.

\section{B. Penyajian Materi}

\section{Potensi Manusia (Jasmani dan Ruhani) dalam}

\section{Pengembangan IPTEKS}

Ada beberapa pendapat yang membahas tentang potensi-potensi yang dimiliki oleh manusia. Rakhmad (2005), ada tiga potensi yang dimiliki oleh manusia, yaitu potensi ruh, jasmani (fisik), dan rohaniah. Ruh berisikan potensi manusia untuk bertauhid, yang merupakan kecenderungan untuk mengabdikan diri kepada Sang Pencipta. Potensi jasmani mencakup konstitusi biokimia yang secara materi teramu dalam tubuh. Potensi rohani berupa konstitusi non-materi yang terintegrasi dalam jiwa, termasuk ke dalam naluri penginderaan, intuisi, bakat, kepribadian, intelek, perasaan, akal, dan unsur jiwa yang lainnya.

Imam al-Ghazali, manusia mempunyai empat kekuatan (potensi), yaitu (1) qalb merupakan suatu unsur yang halus, 
berasal dari alam ketuhanan, berfungsi untuk merasa, mengetahui, mengenal, diberi beban, disiksa, dicaci, dan sebagainya yang pada hakikatnya tidak bisa diketahui; (2) ruh, yaitu sesuatu yang halus yang berfungsi untuk mengetahui tentang sesuatu dan merasa, ruh juga memiliki kekuatan yang pada hakikatnya tidak bisa diketahui; (3) nafs, yaitu kekutan yang menghimpun sifat-sifat tercela pada manusia; dan (4) 'aql, yaitu pengetahuan tentang hakikat segala keadaan, maka akal ibarat sifat-sifat ilmu yang tempatnya di hati (AlGhazali, 1995).

Sumber ilmu selain wahyu dalam epistemologi Islam adalah akal ('aql) dan kalbu (qalb). 'Aql sebagai masdhar tidak disebutkan dalam al-Qur'an, tetapi sebagai kata kerja 'aqala dengan segala akar katanya terdapat dalam Al-Qur'an sebanyak 49 kali. Semuanya menunjukkan unsur pemikiran pada manusia (Wan Daud, 1997).

Bentuk عقلوه disebutkan satu kali. Hal ini sebagaimana firman Allah berikut: 


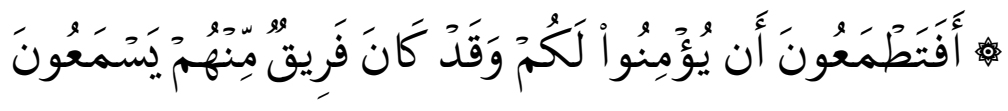

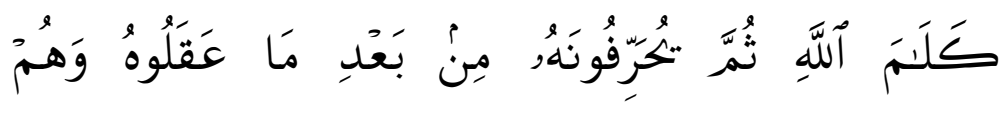

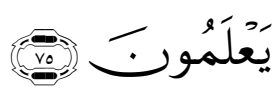

"Apakah kamu masih mengharapkan mereka akan percaya kepadamu, Padahal segolongan dari mereka mendengar firman Allah, lalu mereka mengubahnya setelah mereka memahaminya, sedang mereka mengetahui?." (Q.S. AlBaqarah [2]: 75)

Bentuk تعقلون disebutkan sekitar 24 kali, yaitu dalam firman Allah berikut:

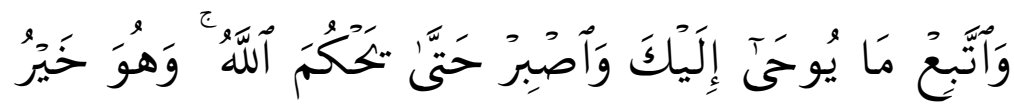

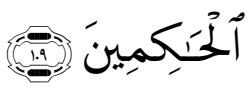

"dan ikutilah apa yang diwahyukan kepadamu, dan bersabarlah hingga Allah memberi keputusan dan Dia adalah hakim yang sebaik-baiknya." (Q.S. Yunus [10]: 109)

Bentuk نعقل disebutkan satu kali, yaitu dalam firman Allah berikut: 


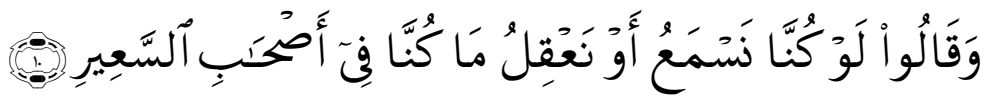

"dan mereka berkata: "Sekiranya Kami mendengarkan atau memikirkan (peringatan itu) niscaya tidaklah Kami Termasuk penghuni-penghuni neraka yang menyala-nyala". (Q.S. Al-Mulk [67]: 10)

Bentuk يعقلها disebutkan satu kali, yaitu dalam firman

Allah berikut:

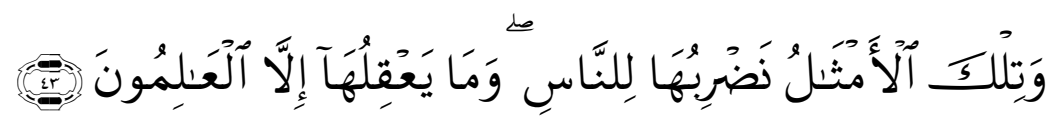

"dan perumpamaan-perumpamaan ini Kami buat untuk manusia; dan tiada yang memahaminya kecuali orang-orang yang berilmu." (Q.S. Al-A'kabut [29]: 43)

Bentuk يعقلون disebutkan sekitar 22 kali, yaitu dalam firman Allah berikut:

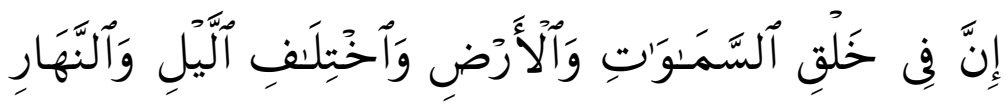

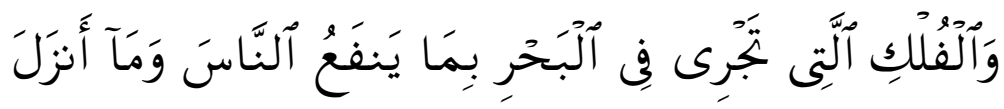

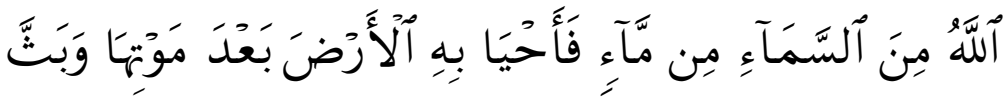




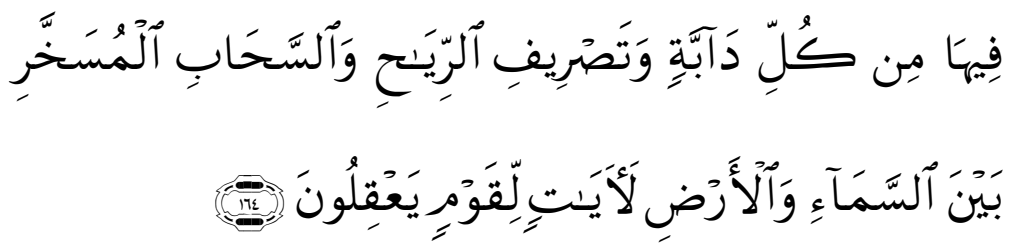

"Sesungguhnya dalam penciptaan langit dan bumi, silih bergantinya malam dan siang, bahtera yang berlayar di laut membawa apa yang berguna bagi manusia, dan apa yang Allah turunkan dari langit berupa air, lalu dengan air itu Dia hidupkan bumi sesudah mati (kering)-nya dan Dia sebarkan di bumi itu segala jenis hewan, dan pengisaran angin dan awan yang dikendalikan antara langit dan bumi; sungguh (terdapat) tanda-tanda (keesaan dan kebesaran Allah) bagi kaum yang memikirkan." (Q.S. Al-Baqarah [2]: 164)

Sejalan dengan arti akal, pikiran dan rasio itu, Al-Qur'an juga memakai kata 'pikir' dalam 18 ayat, seperti: 'afala tatafakkaruun (apakah kamu tidak berpikir), la'allakum tatafakkaruun (agar kamu berpikir). Untuk pengajaran yang sama Al-Qur'an juga menggunakan istilah dabbara (memperhatikan), nazhara (nalar, atau penalaran, memperhatikan dengan pikiran rasio sampai kepada penelitian secara ilmiah). Di dalam 328 ayat yang lain dipakai istilah ra-a (melihat, memahami), untuk memberikan dorongan atau rangsangan dalam menghayati kebesaran dan kekuasaan Allah dengan kesempurnaan ciptanNya. Melalui ayat-ayat ini manusia diajak mengetahui, menghayati, mengerti, merasakan, dan akhirnya mengimani. Setelah iman menjelma, karena 
terus-menerus diulang dan setiap ulangan bervariasi konteks serta bentuk masing-masing, maka diharapkan manusia tunduk berserah diri sepenuhnya kepada Allah SWT (Trianto, 2007).

Berdasarkan ayat-ayat tersebut di atas, Al-Qur'an memberikan motivasi agar manusia menggunakan akal fikiran untuk membaca dan mengamati fenomena-fenomena alam semesta. Hal ini karena akal merupakan rahmat Allah yang paling besar di samping petunjuk agama yang dilimpahkan kepada manusia (Kaelany, 1992). Melalui akal manusia inilah manusia menghasilkan IPTEK yang super canggih.

Dengan demikian, Al-Qur`an adalah inspirator bagi ilmuan, hal ini dikarenakan bahwa dalam al-Qur'an terkandung teks-teks (ayat-ayat) yang mendorong manusia untuk melihat, memandang, berfikir, serta mencermati fenomena-fenomena alam semesta ciptaan Tuhan yang menarik untuk diselidiki, diteliti dan dikembangkan. Al-Qur'an menantang manusia untuk menggunakan akal fikirannya seoptimal mungkin. Hal ini terlihat diantaranya dari firman Allah berikut:

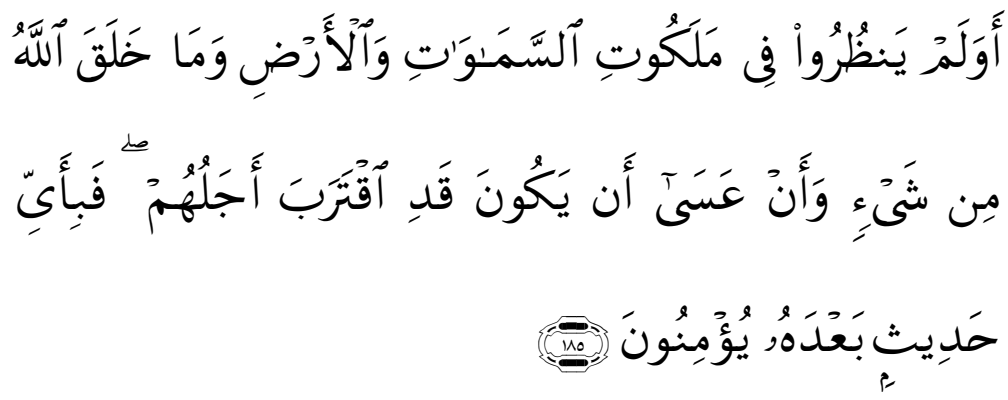


"dan Apakah mereka tidak memperhatikan kerajaan langit dan bumi dan segala sesuatu yang diciptakan Allah, dan kemungkinan telah dekatnya kebinasaan mereka? Maka kepada berita manakah lagi mereka akan beriman sesudah Al Quran itu?." (Q.S. Al-A'raf [7]: 185)

Ayat di atas secara jelas menggambarkan tentang proses penciptaan dan peristiwa-peristiwa masa lalu maupun yang akan datang. Bila dicermati lebih mendalam tiada satu pun ciptaan Allah yang tidak mengandung maksud dan tujuan. Untuk mengungkapkan rahasia dari ciptaan itu, jelas diperlukan pemikiran dan pengkajian yang mendalam atau pengamatan secara langsung, cermat, dan teliti, sehingga dapat dipetik ilmu dan hikmah di balik penciptaanNya. Dengan demikian, alQur'an senantiasa mendesak manusia untuk mengadakan observasi terhadap ciptaan Allah. Melalui pengamatan ini akan dapat mendekatkan diri kepada Sang Khalik.

Al-Qur'an juga mendorong akal manusia untuk melakukan eksplorasi (mengkaji, memilah dan memilih) terhadap fenomena alam yang tergelar, sehingga diperoleh pengetahuan yang banyak. Hal ini sebagaimana firman Allah berikut: 

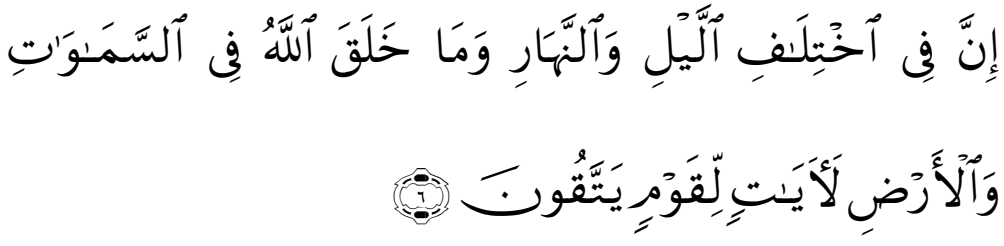

"Sesungguhnya pada pertukaran malam dan siang itu dan pada apa yang diciptakan Allah di langit dan di bumi, benar-benar terdapat tanda-tanda (kekuasaan-Nya) bagi orang- orang yang bertakwa." (Q.S. Yunus [10]: 6)

Trianto (2007) memahami ayat tersebut di atas, pada dasarnya memaparkan fenomena alam sesuai dengan sunnatullah (hukum Allah) yang belaku masih dalam tahap pemaparan. Fenomena tersebut berupa pengaruh penyiraman (air hujan) terhadap pertumbuhan tanaman akan diangkat sebagai metode ilmu pengetahuan.

Selanjutnya Al-Qur'an juga memberikan rangsangan kuat untuk melakukan penelitian tentang adanya kebenaran di balik fenomena fisik dari alam semesta dan kehidupan. Berkaitan dengan hal tersebut ditemui ayat-ayat yang dapat dijadikan rujukan untuk menggali dan mengembangkan ilmu pengetahuan melalui pembuktian. Firman Allah dalam surat An-Nahl sebagai berikut: 


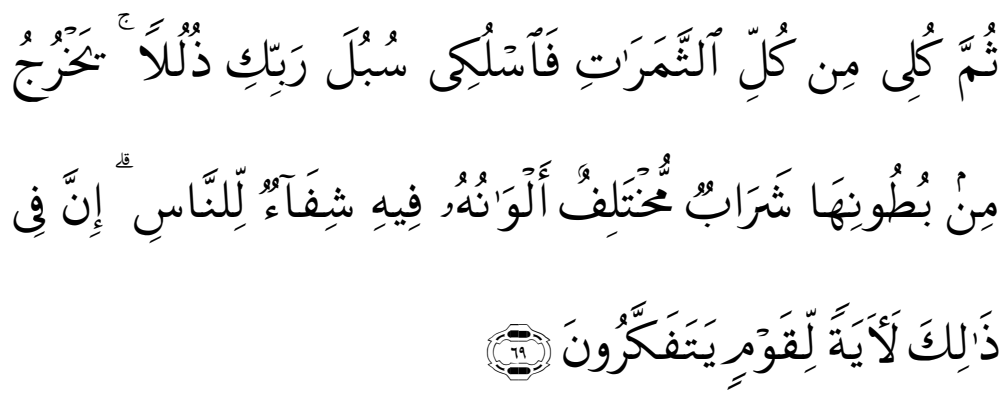

"Kemudian makanlah dari tiap-tiap (macam) buahbuahan dan tempuhlah jalan Tuhanmu yang telah dimudahkan (bagimu). dari perut lebah itu ke luar minuman (madu) yang bermacam-macam warnanya, di dalamnya terdapat obat yang menyembuhkan bagi manusia. Sesungguhnya pada yang demikian itu benar-benar terdapat tanda (kebesaran Tuhan) bagi orang-orang yang memikirkan." (Q.S. An-Nahl [16]: 69)

Untuk memahami ayat di atas, menurut Trianto (2007) tidaklah cukup dengan hanya mengadakan pemahaman secara bahasa saja, melainkan memerlukan penelitian dan eksperimen, yaitu untuk mengetahui zat apakah yang terkandung dalam madu yang keluar dari perut lebah dan penyakit apa saja yang dapat disembuhkan oleh zat tersebut.

Berdasarkan kajian secara eksperimental, terbukti dalam madu terkandung zat gula buah-buahan (fruktosa), yaitu jenis gula yang paling manis dan gula anggur (glukosa), yaitu jenis gula terpenting bagi manusia. Selain itu juga terdapat unit-unit zat sederhana untuk membentuk energy pada semua makhluk hidup. Di dalam madu juga terkandung protein yang disebut 
kloikoprotein, yang berguna untuk tiga hal, yaitu membentuk pembantu-pembantu organ tubuh (enzym); (2) menyusun bermacam-macam hormone; dan (3) membentu jasad-jasad pelawan bibit penyakit (Kaelany, 1992).

Sedangkan kata qalb atau kalbu dalam Al-Qur'an digunakan sebanyak 144 kali. Penggunaan qalb selalu merujuk pada hal-hal yang berkaitan dengan emosi dan akal pada manusia. (Husaini, 2013). Melalui hati (jiwa) tersebut manusia diperintahkan untuk memahami dan belajar dari dirinya sendiri (self orientation). Hal ini sesuai firman Allah berikut:

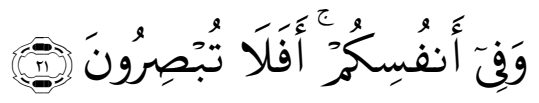

"dan (juga) pada dirimu sendiri. Maka Apakah kamu tidak memperhatikan?." (Q.S. Adz-Dzariyat [51]: 21)

Selanjutnya dalam surat Asy-Syam ayat 7-10 juga disebutkan:
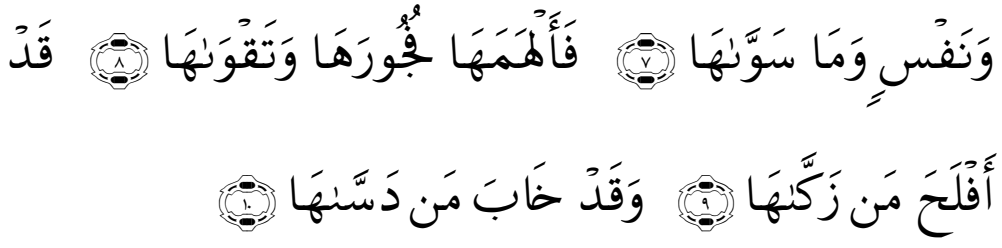

"dan jiwa serta penyempurnaannya (ciptaanNya), maka Allah mengilhamkan kepada jiwa itu (jalan) kefasikan dan ketakwaannya. Sesungguhnya beruntunglah orang yang 
mensucikan jiwa itu, dan sesungguhnya merugilah orang yang mengotorinya." (Q.S. Asy-Syam [91]: 7-10)

Dari ayat di atas terefleksi, bahwa proses perenungan akan ciptaan Allah bukanlah semata-mata dengan memakai kerja otak, tetapi juga mengkonsentrasikan ranah bathin (hati atau jiwa). Hal inilah yang membedakan sifat ilmu pengetahuan dalam Islam dengan Barat. Hati (jiwa) yang dimaksud adalah hati yang tenang, tamaddun, bersih, dan menghamba pada Allah, karena dari hati (jiwa) yang demikian ilham akan masuk.

Menurut Ibn 'Asyur kata 'nafs' pada surat Asy-Syams ayat ke-7 menunjukan nakirah, maka arti kata tersebut menunjukan nama jenis, yaitu mencakup jati diri seluruh manusia seperti arti kata 'nafs' pada surat Al-Infithar ayat 5 yaitu :

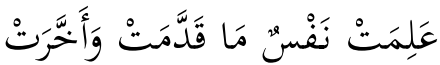

"maka tiap-tiap jiwa akan mengetahui apa yang telah dikerjakan dan yang dilalaikannya." (Q.S. Al-Infithar [82]: 5)

Menurut Al-Qurthubi sebagian ulama mengartikan 'nafs' adalah nabi Adam namun sebagian lain mengartikan secara umum yaitu jati diri manusia itu sendiri. Pada arti kata 'nafs' ini terdapat tiga unsur yaitu: (1) Qolbu (nafs yang terletak di jantung); (2) Domir ( bagian yang samar, tersembunyi dan kasat 
mata); dan (3) Fuad (mempunyai manfaat dan fungsi) (Quthb, 2007).

Nata (2001) mengartikan bahwa an-Naas yaitu untuk menyatakan adanya sekelompok orang atau masyarakat yang mempunyai berbagai kegiatan untuk mengembangkan kehidupannya yaitu:

a. Melakukan kegiatan peternakan (Q.S. Al-Qashash [28] :23).

b. Kemampuan untuk mengelola besi atau logam (Q.S. AthThuur [52]: 25).

c. Kemampuan untuk pelayaran dan mengadakan perubahan sosial (Q.S. Al-Baqarah [2]: 164).

d. Kepatuhan dalam beribadah (Q.S. Al-Baqarah [2]: 21).

Di samping potensi akal dan hati dalam pengembangan IPTEK, manusia juga diberi anugerah potensi jasadiah (fisik) oleh Allah. Potensi jasadiah tersebut ialah kemampuan tubuh manusia yang telah Allah ciptakan dengan sempurna, baik rupa, kekuatan dan kemampuannya. Sebagaimana pada firman Allah berikut:

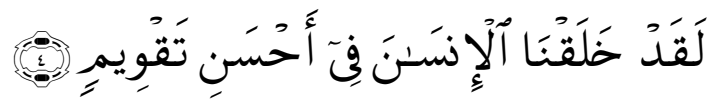

"Sesungguhnya Kami telah menciptakan manusia dalam bentuk yang sebaik-baiknya." (Q.S. At-Tin [95]: 4) 
Kata insan dijumpai dalam al-Qur'an sebanyak 65 kali. Penekanan kata insan ini adalah lebih mengacu pada peningkatan manusia ke derajat yang dapat memberinya potensi dan kemampuan untuk memangku jabatan khalifah dan memikul tanggung jawab serta amanat manusia di muka bumi. Insan dari kata anasa (melihat, mengetahui dan meminta izin). Kata insan menunjuk pada suatu pengertian adanya kaitan dengan sikap yang lahir dari adanya kesadaran penalaran.

Menurut al-Ghazali, pancaindra (potensi jasadiyah) merupakan sarana penangkap pertama yang muncul dari dalam diri manusia, disusul dengan daya khayal yang menyusun aneka bentuk susunan, dari partikular-partikular yang ditangkap indra, kemudian tamyiz (daya pembeda) yang menangkap sesuatu di atas alam empirik sensual di sekitar usia tujuh tahun, kemudian disusul oleh akal yang menangkap hukum-hukum akan yang tidak terdapat pada fase sebelumnya. Panca indera diibaratkan sebagai tentara kalbu yang disebar ke dunia fisis-sensual, dan beroperasi di wilayahnya masingmasing dan laporannya berguna bagi akal. Dan paling penting dominan di antara pancaindra tersebut menurut al-Ghazali adalah indra penglihatan (Anwar, 2007). 


\section{Rambu-Rambu Pengembangan IPTEKS dalam Al-Qur'an dan Hadits}

Pengembangan IPTEKS pada satu sisi memberikan berkah dan manfaat yang sangat besar bagi kesejahteraan hidup manusia bila IPTEKS disertai oleh asas iman dan taqwa kepada Allah SWT. Sebaliknya, tanpa asas iman dan taqwa, IPTEKS bisa disalahgunakan pada tujuan-tujuan yang bersifat destruktif (merusak). Al-Qur'an sebagai dasar pijakan seorang muslim dalam kehidupan ini memberikan kejelasan, bahwa Allah telah menciptakan manusia dengan potensi akal untuk memahami elemen- elemen alam, menyelidiki dan menggunakan benda-benda dalam bumi dan langit demi kebutuhannya. Allah SWT dalam surat al-Israa' berfirman:

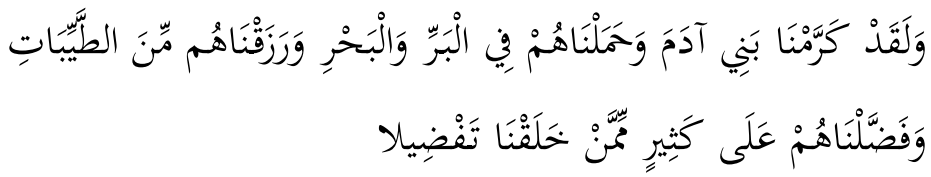

"Dan sesungguhnya telah kami muliakan anak-anak Adam, Kami angkut mereka didaratan dan dilautan, Kami beri mereka rezeki dari yang baik-baik dan Kami lebihkan mereka dengan kelebihan yang sempurna atas kebanyakan makhluk yang telah Kami ciptakan." (Q.S. Al-Israa' [17]: 70)

Dalam ayat tersebut, Al-Qur'an sakhhara yang artinya menundukkan atau merendahkan, maksudnya adalah agar 
alam raya ini dengan segala manfaat yang dapat diraih darinya harus tunduk dan dianggap sebagai sesuatu yang posisinya berada di bawah manusia. Peran manusia sebagai khalifah dimuka bumi menyebabkan alam semesta tunduk dalam kepemimpinan manusia yang sejalan dengan maksud Allah SWT dalam firmanNya berikut:

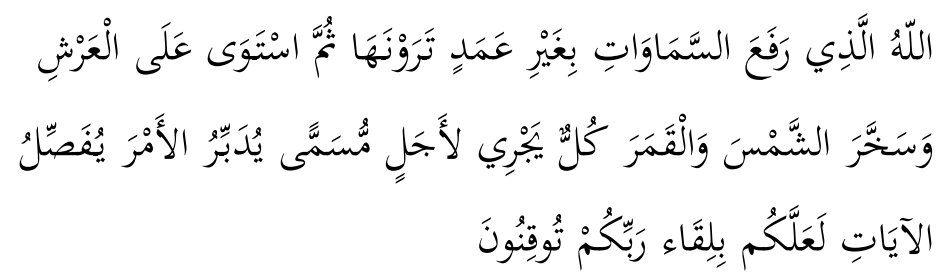

"Allahlah Yang meninggikan langit tanpa tiang (sebagaimana) yang kamu lihat, kemudian Dia bersemayam di atas Arasy, manundukkan matahari dan bulan. Masingmasing beredar hingga waktu yang ditentukan. Allah mengatur urusan (makhluk Nya), menjelaskan tanda- tanda (kebesaranNya), supaya kamu meyakini pertemuan (mu) dengan Tuhanmu." (Q.S. Ar-Ra'du [13]: 2)

Berdasar ayat di atas, menjelaskan bahwa melalui kemampuan akal, ilmu, dan teknolginya manusia dapat meniru segala kekuatan beraneka makhluk, manusia dengan kapal udara dan jet dapat terbang ke udara seperti burung. Manusia dapat menembus bumi dengan teknologinya serta menggali segala mineral dan minyak yang terpendam dalam bumi. Oleh 
karena itu, Islam memberikan rambu-rambu kepada manusia dalam mengembangan IPTEKS, sehingga searah dan sejalan dengan kehendak Allah SWT. Rambu-rambu tersebut diantaranya diuraikan sebagai berikut:

\section{a. Aqidah Islam sebagai dasar IPTEKS}

Menjadikan aqidah Islam dijadikan landasan IPTEKS, bukan berarti konsep-konsep IPTEKS harus bersumber dari AlQur'an dan Al-Hadits, tapi maksudnya adalah konsep IPTEKS harus distandardisasi benar salahnya dengan tolok ukur AlQur'an dan Al-Hadits dan tidak boleh bertentangan dengan keduanya (Al-Baghdadi, 1996). Al-Qur'an dan Hadits dijadikan sebagai tolak ukur benar atau salahnya ilmu pengetahuan dan konsep teknologi itu dan konsep-konsep IPTEK tersebut, tidak boleh lepas dan keluar dari inti kandungan Al-Qur'an dan Hadits.

Dengan demikian, yang dimaksud menjadikan aqidah Islam menjadikan syariah Islam sebagai standar pemanfaatan IPTEKS. Ketentuan halal-haram (hukum-hukum syariah Islam) wajib dijadikan tolok ukur dalam pemanfaatan IPTEKS, bagaimana pun juga bentuknya. IPTEKS yang boleh dimanfaatkan, adalah yang telah dihalalkan oleh syariah Islam. Sedangkan IPTEKS yang tidak boleh dimanfaatkan, adalah yang telah diharamkan syariah Islam. 
Keharusan tolok ukur syariah ini didasarkan pada banyak ayat dan juga hadits yang mewajibkan umat Islam menyesuaikan perbuatannya (termasuk menggunakan IPTEKS) dengan ketentuan hukum Allah dan Rasul-Nya sebagaimana firman Allah berikut:

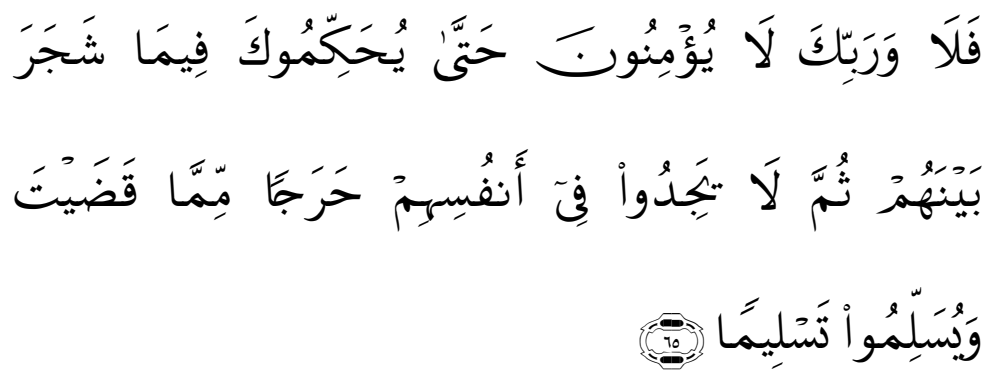

"Maka demi Tuhanmu, mereka (pada hakekatnya) tidak beriman hingga mereka menjadikan kamu hakim terhadap perkara yang mereka perselisihkan, kemudian mereka tidak merasa dalam hati mereka sesuatu keberatan terhadap putusan yang kamu berikan, dan mereka menerima dengan sepenuhnya." (Q.S. an-Nisaa` [4]: 65)

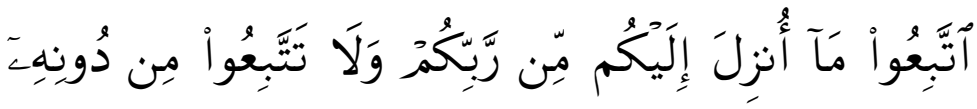

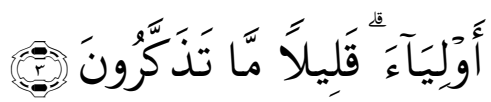


"Ikutilah apa yang diturunkan kepadamu dari Tuhanmu dan janganlah kamu mengikuti pemimpin-pemimpin selainNya. Amat sedikitlah kamu mengambil pelajaran (daripadanya)." (Q.S. al-Araaf [7]: 3)

\section{b. Pengembangan IPTEKS semata-mata untuk mencari}

\section{keridhaan Allah}

Dalam mengembangkan IPTEKS, umat Islam hendaknya memiliki dasar dan motif bahwa yang mereka lakukan tersebut adalah untuk memperoleh kemakmuran dan kesejahteraan di dunia sebagai jembatan untuk mencari keridhaan Allah sehingga terwujud kebahagiaan di dunia dan di akhirat. Allah berfirman dalam Q.S. Al Bayyinah 5:

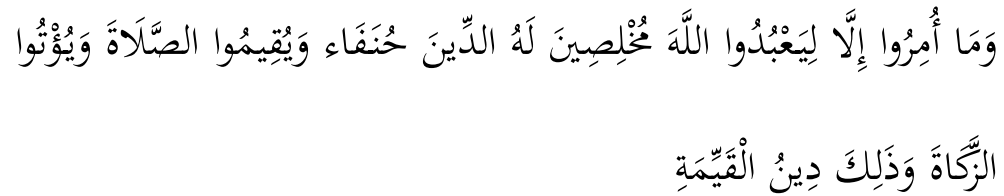

"Padahal mereka tidak disuruh kecuali supaya menyembah Allah dengan memurnikan ketaatan kepada-Nya dalam (menjalankan) agama yang lurus, dan supaya mereka mendirikan shalat dan menunaikan zakat; dan yang demikian Itulah agama yang lurus." (Q.S. Al-Bayyin [98]: 5) 


\section{c. Muatan Etika dalam Pengembangan IPTEKS}

Pengembangan IPTEKS terkandung muatan etika yang selalu menyertai hasil teknologi pada saat akan diterapkan. Sungguh pun hebat hasil teknologi namun jika diniatkan untuk membuat kerusakan sesama manusia, menghancurkan lingkungan sangat dilarang di dalam Islam. Jadi teknologi bukan sesuatu yang bebas nilai, demikian pula penyalahgunaan teknologi merupakan perbuatan zalim yang tidak disukai Allah SWT. Perhatikan FirmanNya:

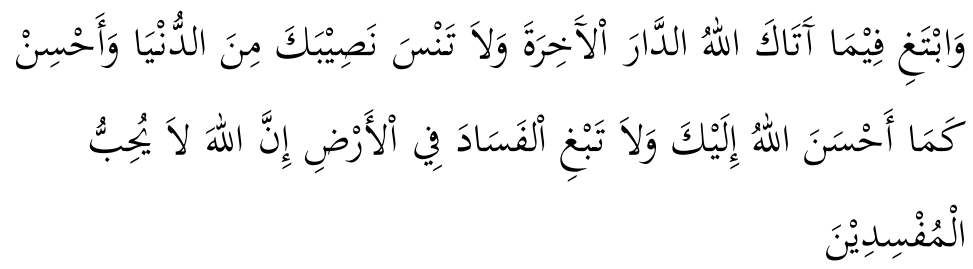

"Dan carilah pada apa yang telah dianugerahkan Allah kepadamu (kebahagiaan) negeri akhirat, dan janganlah kamu melupakan bahagianmu dari (kenikmatan) duniawi dan berbuat baiklah (kepada orang lain) sebagaimana Allah Telah berbuat baik, kepadamu, dan janganlah kamu berbuat kerusakan di (muka) bumi. Sesungguhnya Allah tidak menyukai orang-orang yang berbuat kerusakan." (Q.S. AlQashash [28]: 77)

Dengan demikian, rambu-rambu pengembangan IPTEKS dalam Islam adalah menjadikan paradigma Islam 
sebagai pandangan utama dan menjadikan syariah Islam sebagai dasar dalam penerapan dan pemanfaatan konsep IPTEKS. Perkembangan IPTEKS itu harus diikuti dengan keimanan dan ketakwaan, sehingga pengembangan IPTEKS merupakan hasil dari keterampilan manusia dengan dilandasi Al-Qur'an dan Hadits.

\section{Rangkuman}

1. Potensi akal fikiran dalam pengembangan IPTEKS berfungsi untuk membaca dan mengamati fenomenafenomena alam semesta. Potensi hati untuk mengahayati, merenungi, merasakan dan mengimani kebesaran dan kekuasaan Allah di dalam pencipataanNya. Sementara potensi jasadiah (fisik) diibaratkan sebagai tentara kalbu yang disebar ke dunia fisis-sensual, dan beroperasi di wilayahnya masing-masing dan laporannya berguna bagi akal.

2. Rambu-rambu pengembangan IPTEKS, yaitu pertama menjadikan Aqidah Islam sebagai paradigma pemikiran dan ilmu pengetahuan. Kedua, menjadikan syariah Islam sebagai standar penggunaan IPTEKS, dan ketiga pengembangan IPTEKS terkandung muatan etika yang selalu menyertai hasil teknologi pada saat akan diterapkan. 


\section{Latihan/Tugas/Eksperimen}

Mendiskusikan secara kelompok tentang pengembangan

IPTEKS yang sesuai dengan ajaran Islam dan pengembangan IPTEKS yang bertentangan dengan ajaran Islam.

\section{DAFTAR PUSTAKA}

Al-Baghdadi, Alauddin Ali bin Muhammad bin Ibrahim. 1996. Lubab at-Ta'wil fi Ma'ani at-Tanzil. Beirut: Dar al-Kutub al-'Ilmiyyah.

Al-Ghazali. $\quad 1995 . \quad$ Ringkasan Ihya' Ulumuddin. Jakarta: Pustaka Amani.

Anwar, Saiful. 2007. Filsafat Ilmu Al-Ghazali. Bandung: Pustaka Setia.

Depag RI. 2009. Al-Quran dan Terjemahnya. Jakarta: Yayasan Penyelenggara Penterjemah Al-Quran.

Husaini, Adian. 2013. Filsafat IImu: Perspektif Barat dan Islam. Jakarta: Gema Insani.

Kaelany, HD. 1992. Islam dan Aspek-Aspek Kemasyarakatan. Jakarta: Bumi Aksara.

Nata, Abuddin. 2001. Paradigma Pendidikan Islam: Kapita Selekta Pendidikan Islam. Jakarta: Grasindo.

Quthb, Sayyid. 2007. Tafsir Fi Zhilalil Qur'an. Jakarta: Gema Insani.

Rakhmat, Jalaluddin. 2005. Psikologi Komunikasi. Bandung: PT.Remaja Rosdakarya. 
Trianto. 2007. Wawasan IImu Alamiah Dasar Perspektif Islam dan Barat. Jakarta: Prestasi Pustaka.

Wan Daud, Wan Muhammad Nor. 1997. The Concept of Knowledge in Islam and its Implications for Education in Developing Country. Terj. Munir, Konsep Pengetahuan dalam Islam. Bandung: Pustaka. 


\section{BAB VII}

\section{KEBENARAN AL-QUR'AN DAN HADIST DALAM BIDANG}

\section{ILMU SOSIAL DAN POLITIK}

\section{A. Pendahuluan}

Al-Qur'an sebagai mukjizat terbesar bagi Rasulullah Muhammad SAW dan umatnya. Al-Qur'an adalah Kalamullah (firman Allah) yang diturunkan kepada Rasulullah Muhammad lewat perantara malaikat Jibril yang dinilai ibadah bagi pembacanya. Kebesaran mukjizat Al-Qur'an dapat dibuktikan dengan keotentikan Al-Qur'an sebagai kitab suci yang langsung dari Allah SWT dan kebenaran isi Al-Qur'an sepanjang masa. Maka Al-Qur'an menjadi dustur (aturan tertinggi) bagi orang-orang yang mempercayai dan mengikuti petunjuknya. Sedangkan tentang keotentikan Al-Qur'an selain bisa dibuktikan dari dalil-dalil naqli di Al-Qur'an juga bisa dibuktikan dari bukti-bukti sejarah tentang terjaganya keotentikan AlQur'an sampai kepada kita saat ini.

Rasulullah Muhammad sebagai penerima wahyu (Nabi) yang bertugas menyampaikannya 
kepada umatnya (Rasul) berinteraksi sosial secara langsung dengan umatnya. Dalam masa rasulullah masih hidup beliau adalah sumber rujukan utama bagi segala persoalan individu atau keumatan. Dan tentu adanya jaminan sebagai seorang nabi dan rasul yang hanya menyampaikan kebenaran sesuai wahyu dan bukan menuruti hawa nafsu yang menjadikan sunnah sebagai sumber ajaran agama Islam. Sunnah adalah apa yang zahir dari Nabi Muhammad saw selain dari Al-Qur'an baik yang berupa perkataan, perbuatan, atau pengakuan. Sunnah dibagi menjadi tiga . Pertama, sunnah Qouliyah (perkataan Nabi) Kedua, sunnah Fi'liah (perbuatan Nabi). Dan ketiga, Sunnah Taqririyah (ketetapan Nabi) . Sunnah Qouliyah inilah yang biasa disebut dengan hadist.

Dalam Al-Quran dan hadist selain membahas masalah aqidah dan ibadah banyak juga pembahasan mengenai perkembangan ilmu pengetahuan, kesehatan, teknologi, kehidupan sosial serta politik. Nilai-nilai Islam dalam teori sosial dan politik tersebar dalam ayat-ayat Al-Qur'an dan hadits Rasulullah. Tentu ini sesuai dengan fungsi utama Al-Qur'an sebagai petunjuk bagi manusia. 
Melalui pembahasan materi ini mahasiswa diharapkan mampu menguasai dan mengintegrasikan nilai-nilai Islam dalam pengembangan dan penerapan ilmu pengetahuan terutama dalam bidang ilmu sosial dan politik. Pengembangan dan penerapan ilmu sosial dan politik yang terintegrasikan didalamnya nilai-nilai Islam yang bersumber dari Al-Qur'an dan hadits.

\section{B. Penyajian Materi}

\section{Interelasi Kebenaran Al-Qur'an dan Hadist dalam Bidang Ilmu Sosial dan Politik}

Al-Qur'an dan Hadits yang menjadi sumber utama dalam mengatur kehidupan umat Islam baik kehidupan individu, interaksi individu terhadap lingkungan kehidupan sosialnya ataupun kehidupan sosial itu sendiri tentu terkait dengan pengembangan ilmu pengetahuan sosial dan politik. Interelasi Al-Qur'an dan Hadits terkait sosial kemasyarakatan dan politik bisa dibuktikan dengan dalil-dalil yang berkaitan dengan bidang sosial dan politik. Interelasi bisa diartikan sebagai hubungan antara dua masalah yang saling terkait. Dalam pembahasan ini akan menjelaskan interelasi kebenaran Al-Quran dan Hadist dengan 
bidang sosial dan politik melalui dalil-dalil AlQur'an dan Hadits.

Ketentuan-ketentuan Allah SWT di dalam AlQur'an bersifat absolut berupa kebenarankebenaran Qur'ani dan kebenaran kauni. Kebenaran dalam Al-Quran itu dapat didekati manusia melalui pendalaman secara kontinue (dalil naqli atau aqli) dengan menggunakan landasan Al-Qur'an dan Hadits Rasulullah.

Allah SWT sebelum menciptakan Nabi Adam telah menyampaikan tujuan penciptaan manusia sebagai khalifah di bumi. Sebelum turun ke bumi, Nabi Adam bersama istrinya merasakan dan mendapatkan pengalaman kehidupan surga. Sehingga dengan pengalaman tersebut memperoleh gambaran bagaimana seharusnya membangun dunia. Allah SWT telah memberikan informasi kepada malaikat tentang tujuan penciptaan Adam sebagai khalifah di bumi di surat Al-baqarah ayat 30 : 


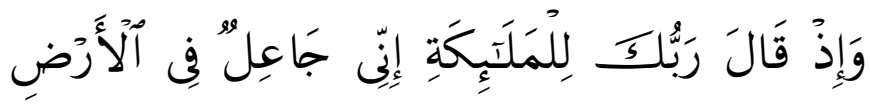
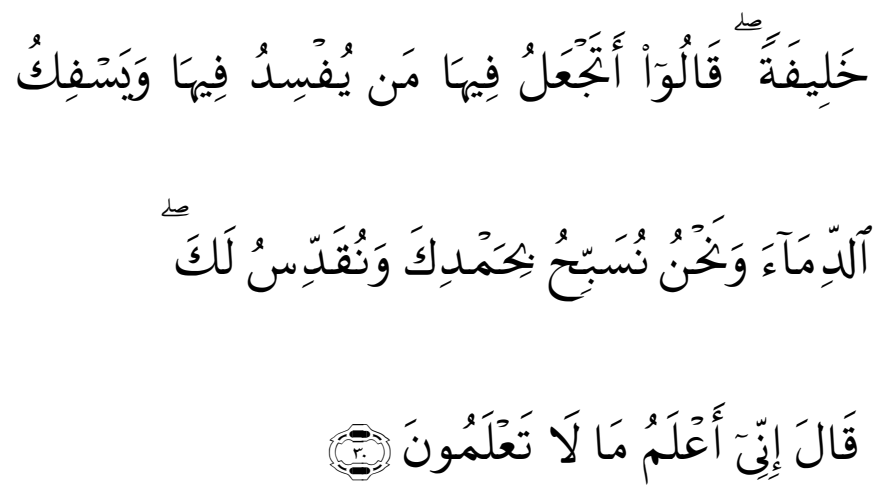

Artinya:"'Ingatlah ketika Tuhan-mu berfirman kepada para malaikat, "Sesungguhnya Aku hendak menjadikan seorang khalifah di muka bumi". Mereka berkata, "Mengapa Engkau hendak menjadikan (khalifah) di bumi itu orang yang akan membuat kerusakan padanya dan menumpahkan darah, padahal kami senantiasa bertasbih dengan memuji Engkau dan menyucikan Engkau?" Tuhan berfirman "Sesungguhnya Aku mengetahui apa yang tidak kamu ketahui”.

Dari ayat ini jelas juga tentang kecenderungan manusia untuk berbuat kerusakan di bumi serta 
timbulnya konflik sosial diantara manusia. Maka dengan pengembangan ilmu pengetahuan diharapkan manusia bisa menjadi khalifah yang mengatur kehidupan di bumi serta menerapkan aturan-aturan sosial yang adil berdasarkan nilainilai Islam bersumber dari yang menciptakan Manusia yaitu Allah SWT.

\section{Bukti-Bukti Ilmiah Kebenaran Al-Qur'an dan Hadist dalam Bidang Ilmu Sosial dan Politik}

Banyak kebenaran ilmiah yang dipaparkan oleh Al-Qur'an tetapi tujuan pemaparan kebenaran ilmiah ini untuk menunjukkan kebesaran dan Ke-Esa-an Allah serta mendorong manusia untuk mengadakan observasi dan penelitian demi lebih menguatkan iman kepada Allah SWT. Dapat dipahami bahwa Al-Qur'an tidaklah diturunkan untuk menjadi satu kitab ilmiah tetapi tujuan pokok diturunkannya AlQur'an adalah memberikan petunjuk kepada manusia demi kebahagian hidup di dunia dan akhirat. 
Kepedulian ajaran Islam terhadap kehidupan sosial politik sangat tampak jelas dalam AlQur'an dan Hadits. Manusia yang diciptakan terdiri dari laki-laki dan perempuan, bersuku-suku dan berbangsa-bangsa tentu akan membuat manusia menjadi makhluk sosial yang saling membutuhkan antara satu dan yang lainnya dan menimbulkan adanya kerjasama diantara manusia. Kondisi ini disebutkan dalam Al-Qur'an surat Hujurat ayat 13 :

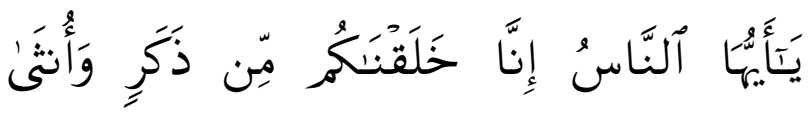

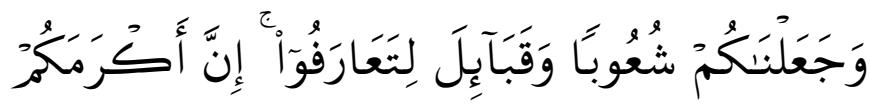

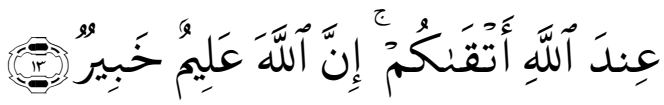

Artinya: "Hai manusia, sesungguhnya Kami menciptakan kamu dari seorang laki-laki dan seorang perempuan dan menjadikan kamu berbangsa-bangsa dan bersuku-suku supaya kamu saling mengenal. Sesungguhnya orang yang paling mulia diantara kamu di sisi Allah 
ialah orang yang paling bertakwa diantara kamu. Sesungguhnya Allah Maha Mengetahui lagi Maha Mengenal”.

Manusia sebagai makhluk sosial dituntut pula untuk mempunyai kepedulian sosial terhadap lingkungan sosial masyarakat. Isyarat untuk mempunyai kepedulian sosial lingkungan yang akan berdampak kepada terbentuknya masyarakat yang ideal disampaikan oleh Rasulullah dalam haditsnya :

عَنْ أَبْيْ هُرَبْرَةَ رَضِيَ اللهُ عَنْهُ فَالَ: قَالَ رَسُوْلُ

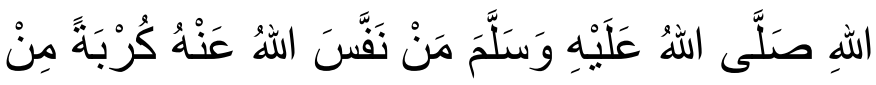

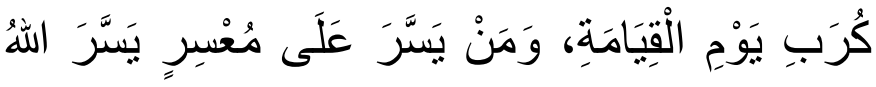
عَلَيْهِ فِي الأُنْيَا وَالآخِرَةِ، وَمَنْ سَتَرَ مُسنْلِماً سَتَرَهُ اللهُ فِي الأُنْبَا وَالآخِرَةِ وَاللهُ فِي عَوْنِ الْعَبْدِ مَا كَانَ الْعَبُْ

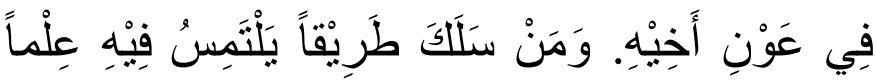

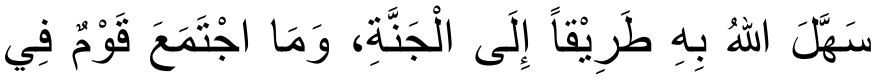

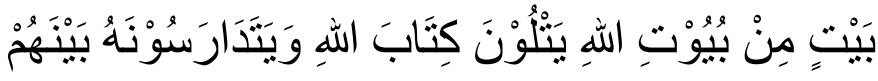

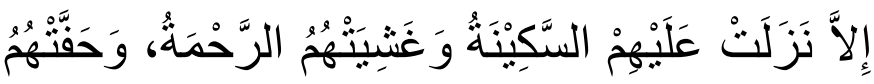




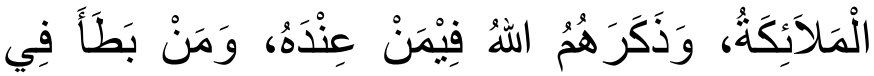

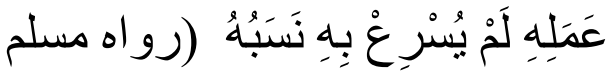

"Dari Abu Hurairah r.a, dari Rasulullah saw bersabda: "Barangsiapa yang melapangkan salah satu kesusahan dunia dari seorang Mukmin, maka Allah melapangkan darinya salah satu kesusahan Hari Kiamat. Barangsiapa memudahkan atas orang kesulitan, maka Allah memudahkan atasnya di dunia dan akhirat. Barangsiapa menutupi (aib) seorang muslim, maka Allah menutupi (aib)nya di dunia dan akhirat. Allah senantiasa menolong hamba selagi hamba tersebut senantiasa menolong saudaranya. Barangsiapa yang meniti suatu jalan untuk mencari ilmu, maka Allah memudahkan untuknya jalan menuju surga. Tidaklah suatu kaum berkumpul di salah satu rumah Allah, untuk membaca Kitabullah dan mempelajaarinya di antara mereka, melainkan ketentraman turun atas mereka, rahmat meliputi mereka, malaikat meliputi mereka, dan Allah menyanjung mereka ditengah para Malaikat yang berada disisiNya. Barangsiapa yang amalnya kurang, maka nasabnya tidak 
mengantarkannya (kepada derajat yang shahih)"'(HR. Muslim)

Sedangkan kebenaran Al-Qur'an dalam bidang politik untuk mengatur ketertiban bermasyarakat dan bernegara dengan perintah yang jelas agar mentaati Ulul amri (pemimpin) setelah ketaatan kepada Allah dan RasulNya. Firman Allah SWT dalam surat An-Nisa' ayat 59 :

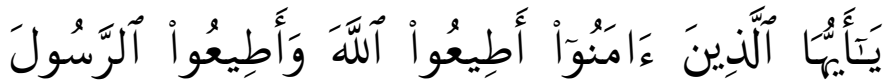

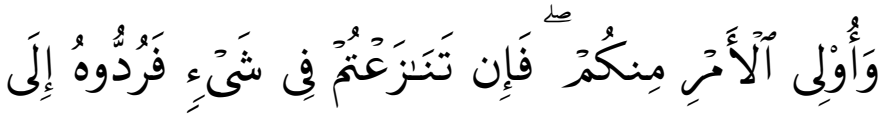

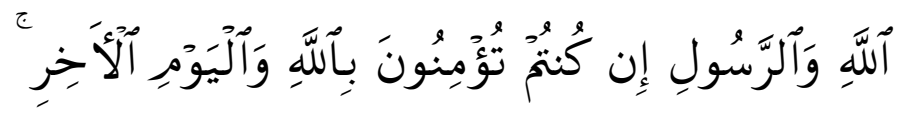

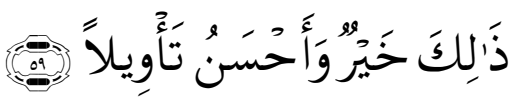

Artinya: "Hai orang-orang yang beriman, taatilah Allah dan taatilah rasul-(Nya), dan ulil amri diantara kamu, kemudian jika kamu berlainan pendapat tentang sesuatu, maka 
kembalikanlah ia kepada Allah (Al-Qur'an) dan rasul (sunahnya), jika kamu benar-benar beriman kepada Allah dan hari kemudian. Yang demikian itu lebih utama (bagimu) dan lebih baik akibatnya."

\section{RANGKUMAN}

1. Interelasi kebenaran Al-Qur'an dan hadist dalam bidang sosial politik dapat dijelaskan melalui dalil-dalil Al-Quran maupun hadist, diantaranya adalah tentang kecenderungan manusia untuk berbuat kerusakan di bumi serta timbulnya konflik sosial diantara manusia.

2. Diantara bukti-bukti ilmiah kebenaran AlQuran dalam bidang sosial politik adalah manusia sebagai makhluk sosial, manusia dituntut untuk mempunyai kepedulian sosial, serta perintah agar mentaati ulil amri (pemerintah).

\section{EVALUASI}

Untuk memperdalam pemahaman anda tentang materi diatas, maka diskusikan bersama kelompok tentang dalil-dalil lainnya mengenai Interelasi 
kebenaran dalam Al-Quran maupun hadist dalam bidang sosial politik.

\section{E. DAFTAR PUSTAKA}

Departemen Agama RI. 2004. Al-Qur'an dan

Terjemah. Bandung: . Al-Jumanatul 'Ali.

Maarif, Ahmad Syafii. 1996. Islam dan Politik -

Teori Belah Bambu . Jakarta: Gema Insani Press.

Rahman, Fazlur. 1996. Tema Pokok AlQur'an. Bandung: Pustaka.

Shihab, M. Quraish. 1998. Wawasan AlQur'an. Bandung: Mizan. 


\section{BAB VIII}

\section{PARADIGMA ISLAM TENTANG ILMU SOSIAL DAN POLITIK}

\section{A. Pendahuluan}

Ilmu sosial merupakan ilmu yang mempelajari tindakan yang berlangsung dalam proses kehidupan. Sedangkan ilmu politik termasuk cabang dari ilmu sosial. Islam sebagai pedoman dan pegangan moral bagi individu-individu yang ada di muka bumi dalam menjalankan kehidupan, sangat menganjurkan perlunya menciptakan tata kehidupan yang serasi. Hal ini sangat berhubungan dengan ilmu sosial dan politik. Prinsip amar ma'ruf nahi munkar (memerintahkan yang ma'ruf dan mencegah yang munkar) berulangulang kita temui dalam Al-Qur'an, disamping kewajiban menghapuskan fasaad fii al-ardh (korupsi/ kerusakan di bumi).

Tata sosiopolitik islami harus ditegakkan agar tidak dikatakan beragama secara formal, sedangkan batin masih dikemudikan oleh kecenderungan etika politik yang bercorak pra-Islam. Namun Islam adalah 
agama yang optimistik menghadapi masa depan. Ditengah agama lain yang sudah menyesuaikan diri dengan arus sekularisme yang membanjiri dunia, Islam masih penuh semangat bahwa penciptaan tata kehidupan dengan dasar wahyu merupakan sesuatu yang mungkin.

Untuk mengetahui sejauhmana paradigma Islam tentang ilmu sosial dan politik, pada materi ini diharapkan mahasiswa mampu memahami hakikat ilmu sosial dan politik dalam perspektif Islam, mampu mengetahui keutamaan mempelajari ilmu sosial dan politik serta mampu mendeskripsikan teori-teori ilmu sosial dan politik dalam Islam.

\section{B. Penyajian Materi}

\section{Hakikat Ilmu Sosial dan Politik dalam Perspektif} Islam

Ilmu sosial pada hakikatnya tentang tata cara dalam hubungan dengan lingkungan masyarakat luas dan aspek-aspek sosial dalam kehidupan sesama makhluk. Keseluruhan dari cabang ilmu sosial memiliki hakikat masing-masing dalam perspektif Islam. 
Cabang dari ilmu sosial diantaranya adalah:

a. Hukum

Hukum merupakan sebuah sistem untuk membatasi dan mengontrol tingkah laku manusia dan menjadi landasan hidup bagi warga negara agar memahami aturan-aturan dalam negara.

Pada hakikatnya, proses penetapan hukum atau terhadap pihak yang berselisih, Al-Quran sangat menuntut keadilan. Keadilan adalah syarat bagi terciptanya kesempurnaan pribadi, standart kesejahteraan masyarakat, dan sekaligus jalan terdekat menuju kebahagiaan ukhrawi. Kehadiran para Rasul ditegaskan Al-Quran bertujuan untuk menegakkan sistem kemanusiaan yang adil. Sebagaimana dalam firmanNya QS. Al-Hadid ayat 25 :

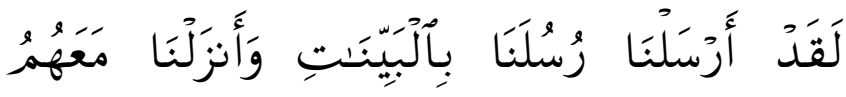

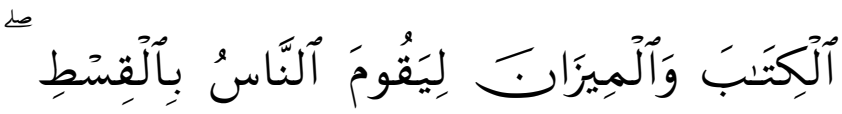

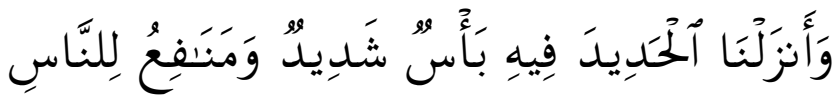




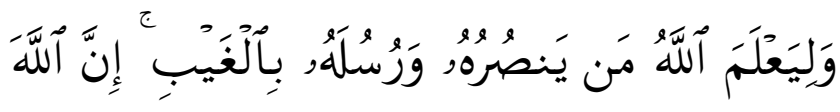

$$
\text { قَوَى عَزَيزْ }
$$

"Sesungguhnya Kami telah mengutus rasulrasul, dengan membawa bukti-bukti nyata, dan telah Kami turunkan bersama mereka Al-Kitab dan neraca (keadilan) agar manusia dapat melaksanakan keadilan."

Dalam ayat lain Al-Quran juga memerintahkan kepada manusia untuk menegakkan hukum atau berlaku adil.

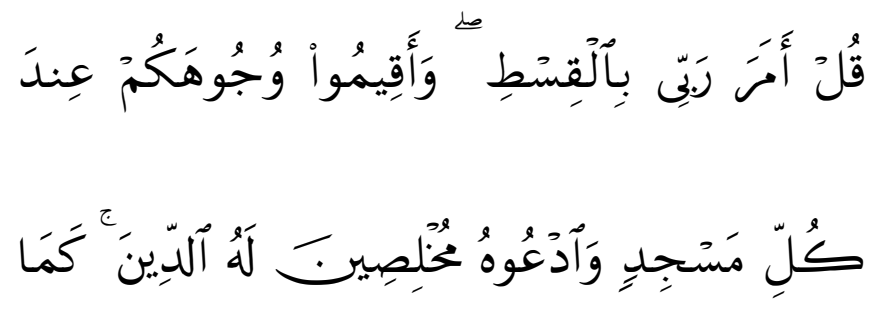

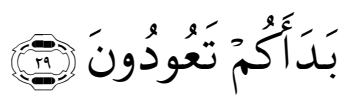


"katakanlah, "Tuhanku memerintahkan menjalankan al-qisth (keadilan)." (QS. AlA'raf:29).

b. Geografi

Geografi merupakan ilmu yang mempelajari mengenai seluk beluk bumi, baik bentuk maupun seluruh isinya. Hakikat ilmu geografi dalam perspektif Islam adalah meyakini bahwa Allah adalah pemilik mutlak dan penguasa dari alam semesta. Karena kekuasaannya yang mutlak, maka jika Allah hendak menciptakan langit dan bumi, maka Dia berkata kepada keduanya: "Jadilah kalian, baik dengan suka maupun dengan terpaksa!” (QS. Fushilat: 11)

Fenomena alam yang terjadi menggambarkan kekuasaan serta kebesaran Allah yang tak terhingga dan menyerukan agar manusia beriman kepadaNya, atau menggambarkan belas kasihNya yang tak terhingga dan m,enyerukan agar manusia bersyukur kepadaNya. Perbedaan terpenting antara Allah dan ciptaanNya adalah jika Allah tak terhingga dan mutlak, maka setiap sesuatu yang 
diciptakanNya adalah terhingga. Bila Allah menciptakan sesuatu, maka kepadanya Dia memberikan kekuatan atau hukum tingkah laku yang di dalam Al-Qur'an dikatakan "petunjuk", atau "perintah", yang dengan hukum tingkah laku tersebut ciptaanNya dapat selaras dengan ciptaanciptaanNya yang lain di dalam alam semesta. Sebagaimana dalam firmanNya QS. Al-A'la ayat 2-3:

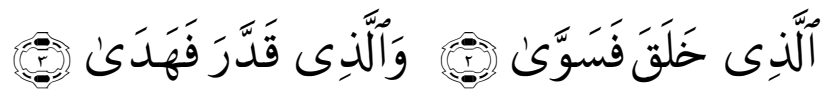

"Dialah yang menciptakan (segala sesuatu) dengan sebaik-baiknya, dan yang memberikan ukuran (kepada segala sesuatu itu) dan (oleh karena itu) memberikan petunjuk (kepada mereka)."

c. Sosiologi

Pola hubungan manusia dalam kehidupan bermasyarakat secara luas akan dibahas dalam ilmu sosiologi. Seseorang yang memahami ilmu sosiologi dengan baik akan dapat bersosialisasi dengan baik pula. Hal ini sejalan dengan tujuan 
utama Al-Qur'an adalah menegakkan sebuah tatanan masyarakat yang adil berdasarkan etika dan dapat bertahan dimuka bumi ini. Apabila ada lebih dari seorang manusia, maka Allah secara langsung masuk ke dalam hubungan diantara mereka.

Ayat kedua dari wahyu pertama yang diterima Nabi Muhammad SAW, dapat dipahami sebagai salah satu ayat yang menjelaskan tentang manusia adalah "makhluk sosial". Khalaqal insana min 'alaq bukan saja diartikan sebagai " menciptakan manusia dari segumpal darah" atau "sesuatu yang berdempet di dinding rahim", tetapi juga dapat dipahami sebagai "diciptakan dinding dalam keadaan salalu bergantung kepada pihak lain atau tidak dapat hidup sendiri”. Dalam surat AlHujurat ayat 13 juga secara tegas dinyatakan bahwa manusia diciptakan terdiri dari laki-laki dan perempuan, bersuku-suku dan berbangsabangsa, agar mereka saling mengenal. Dengan demikian dapat dikatakan bahwa, menurut AlQur'an, manusia secara fitri adalah makhluk 
sosial dan hidup bermasyarakat merupakan satu keniscayaan bagi mereka.

d. Sejarah

Sejarah merupakan ilmu yang mempelajari mengenai peristiwa yang terjadi pada masa lampau umat manusia. Al-Qur'an sebagai pedoman umat muslim sangat padat akan ilmu sejarah, baik yang mengisahkan tentang kehidupan Rosulullah, kehidupan dan perjuangan para nabi, dan lain-lain yang pada hakikatnya akan mempertebal keimanan seseorang. Islam membedakan antara orang yang berserah diri kepada tuntunan Allah dengan menaati hukumhukumNya (muslim) dan orang yang memiliki keyakinan teguh (mukmin). Keimanan inilah yang akan diteguhkan dengan mempelajari ilmu sejarah.

e. Politik

Kata politik dalam kamus besar bahasa Indonesia diartikan sebagai "segala urusan dan tindakanb(kebijakan, siasat dan sebagainya) 
mengenai pemerintahan negara atau terhadap negara lain." Juga bisa berarti "kebijakan, cara bertindak (dalam menghadapi atau menangani suatu masalah)." Dalam bahasa arab, kata politik diterjemahkan dengan kata siyasah. Politik pada dasarnya berhubungan dengan masalah mengatur urusan rakyat, sedangkan politik dalam perspektif Islam adalah pengaturan kepentingan umat baik dalam negeri maupun luar negeri berdasarkan hukum Islam. Rasulullah SAW bersabda:

"Adalah bani Israel, para Nabi selalu mengatur urusan mereka. Setiap seorang Nabi meninggal, diganti Nabi berikutnya. Dan sungguh tidak ada lagi Nabi selainku. Akan ada para khalifah yang banyak." (HR Muslim dari Abu Hurairah ra).

Dari hadits diatas menjelaskan bahwa pengaturan kepentingan umat setelah masa Rasulullah adalah khalifah. Sedangkan hubungan antara politik dan Islam sangat erat. Agama adalah dasar atau pondasi, dan kekuasaan adalah penjaganya. Jika keduanya tidak berjalan seiring 
maka akan terjadi kekacauan politik dan perebutan kekuasaan.

Berpolitik merupakan kewajiban bagi setiap muslim baik laki-laki maupun perempuan. Allah telah menganjurkan kepada kaum muslim untuk menjalankan pemerintah Islam berdasarkan hukum syara. Sebagaimana firman Allah dalam QS. Al-Maidah: 48:

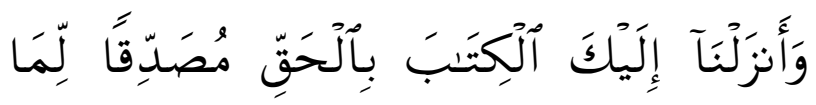

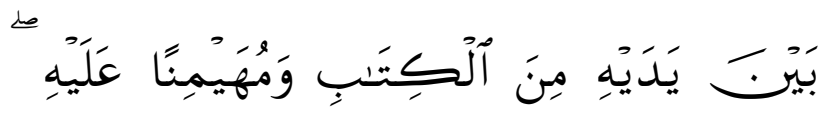

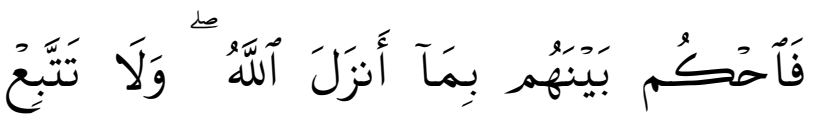

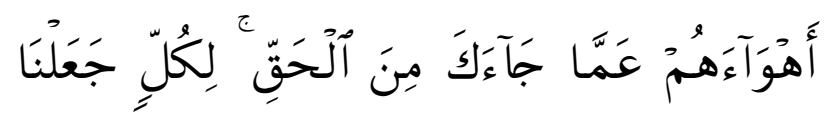

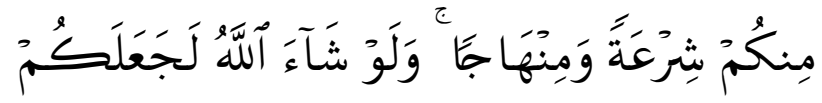

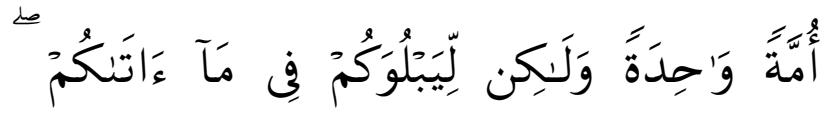




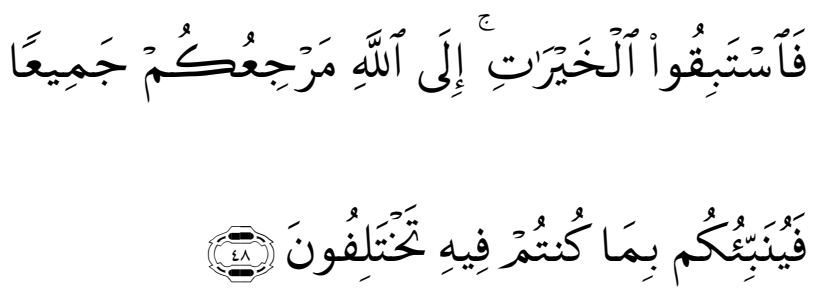

Artinya: Maka putuskanlah perkara mereka menurut apa yang diturunkan oleh Allah SWT dan janganlah kamu mengikuti hawa nafsu mereka dengan meninggalkan kebenaran yang telah datang kepadamu."

Selain diatas, masih banyak cabang ilmu sosial lain, diantaranya ekonomi, psikologi dan antropologi yang akan dibahas pada bab tersendiri.

\section{Keutamaan Mempelajari Ilmu Sosial dan Politik}

Keutamaan mempelajari ilmu sosial, diantaranya adalah:

a. Memudahkan manusia untuk hidup dalam suatu kelompok masyarakat

b. Mempertebal keimanan dan memperkuat nilai agama dalam aspek sosial beragama 
c. Mengetahui cara berinteraksi dengan sesama manusia

d. Memahami cara berkomunikasi dengan masyarakat luas

e. Meningkatkan kesadaran dalam melestarikan dan memanfaatkan lingkungan

f. Memiliki keahlian dalam problem solving terhadap permasalahan sosial yang terjadi dalam kehidupan bermasyarakat.

g. Memiliki jiwa sosial yang tinggi

Keutamaan mempelajari ilmu politik, diantaranya adalah:

a. Meningkatkan sifat amanah

b. Lebih mementingkan kepentingan umum dari pada kepentingan pribadi

c. Mengetahui cara pengambilan keputusan yang benar

d. Meningkatkan ketaatan kepada ulil amri

e. Lebih bersikap adil dan bijaksana 


\section{Teori-Teori Ilmu Sosial dan Politik dalam Islam}

\section{a. Teori Keadilan dalam Islam}

Kata keadilan diungkapkan oleh AlQur'an antara lain dengan kata al-'adl, alQisth, dan al-mizan. 'Adl artinya sama atau tidak berat sebelah/ tidak memihak. Hal ini memberi kesan adanya dua pihak atau lebih, karena jika satu pihak, tidak akan terjadi persamaan. Dalam surat Al-Maidah ayat 8 ditemukan isyarat perlunya mendahulukan keadilan, karena keadilan mengantarkan kepada ketakwaan. Firman Allah: "Berlaku adillah! Karena adil itu lebih dekat dengan takwa"

Berbeda dengan Qisth yang berarti "bagian". Bagian dapat diperoleh oleh satu pihak. Dalam Al-Qur'an, untuk menuntut seseorang berlaku adil terhadap dirinya sendiri menggunakan kata qisth. Sebagaimana dalam firmanNya surat Al-Nisa' ayat 135: 


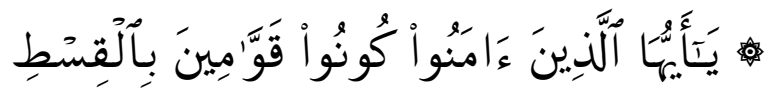

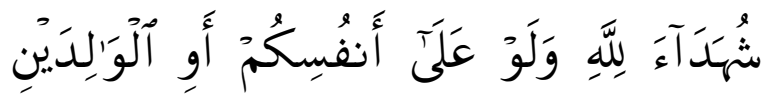

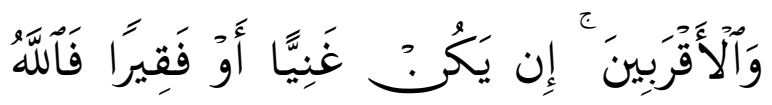

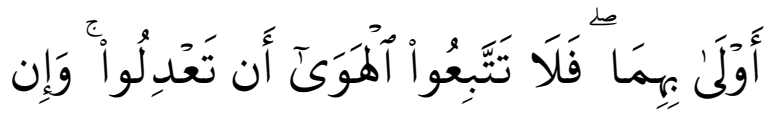

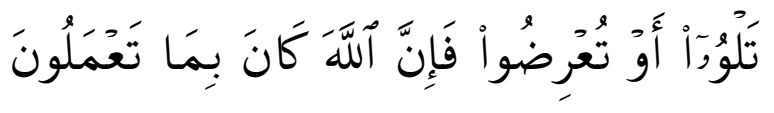

$$
\begin{aligned}
& \text { خَبِيرًا }
\end{aligned}
$$

"Wahai orang-orang yang beriman, jadilah kamu orang yang benar-benar penegak keadilan, menjadi saksi karena Allah biarpun terhadap dirimu sendiri atau ibu bapa dan kaum kerabatmu. Jika ia kaya ataupun miskin, maka Allah lebih tahu kemaslahatannya. Maka janganlah kamu mengikuti hawa nafsu karena ingin menyimpang dari kebenaran. Dan jika 
kaти memutar balikkan (kata-kata) atau enggan menjadi saksi, maka sesungguhnya Allah adalah Maha Mengetahui segala apa yang kamu kerjakan”.

Keadilan juga diungkapkan dengan kata al-mizan yang artinya alat untuk menimbang (neraca). Firman Allah surat AlHadid ayat 25 menggunakan kata mizan untuk menjelaskan kehadiran para Rasul dalam menegakkan sistem kemanusiaan yang adil.

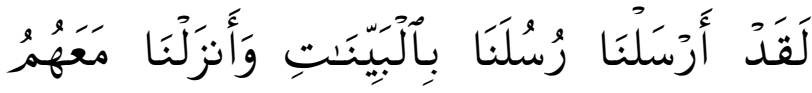

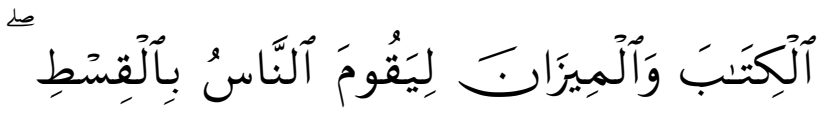

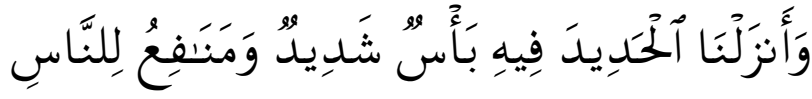

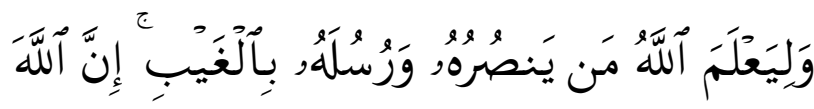

$$
\text { قَوكَّ عَزيزَ }
$$


"Sesungguhnya Kami mengutus rasul-rasul, dengan membawa bukti-bukti nyata, dan telah Kami turunkan bersama merekaAl-Kitab dan neraca (keadilan) agar manusia melaksanakan keadilan".

Keadilan dalam Al-Qur'an menuntut keadilan tidak hanya pada proses penetapan hukum pada ihak yang berselisih, namun juga menuntut keadilan terhadap diri sendiri. Keadilan merupakan syarat terciptanya kesempurnaan pribadi, standart kesejahteraan masyarakat dan jalan menuju kebahagiaan ukhrawi. Konsepsi keadilan Islam mengandung makna menenmpatkan sesuatu pada tempatnya, memberikan sesuatu yang menjadi haknya secara seimbang dan membebankan sesuai daya pikul seseorang.

Allah menciptakan dan mengelola alam semesta ini dengan keadilan, dan menuntut agar keadilan mencakup semua aspek kehidupan. Baik aspek akidah,syariah, akhlak 
bahkan cinta maupun benci. Sebagaimana firman Allah tentang keadilan dalam hal cinta.
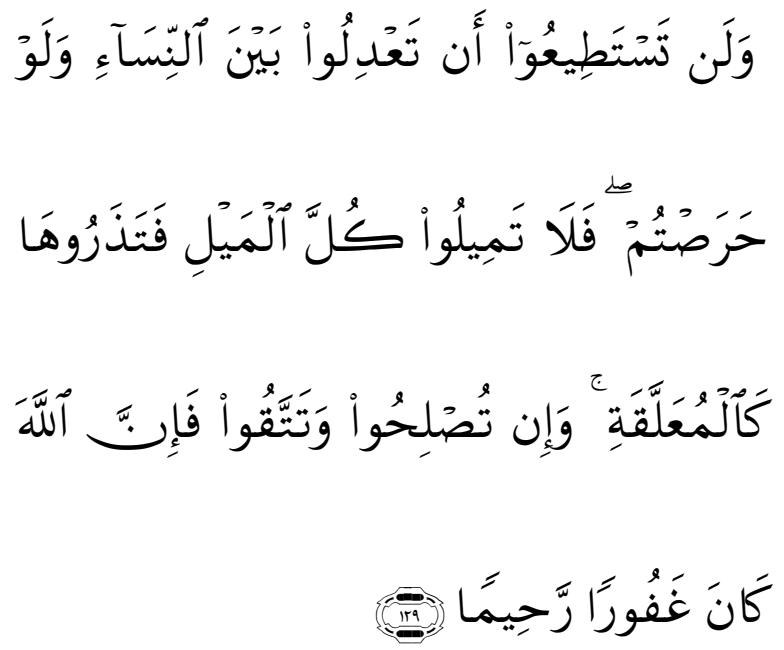

"Dan kamu pasti tidak akan dapat berlaku adil di antara wanita-wanita (istri-istrimu dalam hal cinta), walaupun kamu berusaha keras ingin berbuat demikian. Karena itu janganlah kamu terlalu cenderung (kepada yang kamu cintai), dan membiarkan yang lain terkatung- katung. ” (QS.Al-Nisa':129)

\section{b. Teori Perubahan Sosial dalam Islam}

Masyarakat terdiri dari individu-individu dan unit-unit sosial yang didalamnya beraktivitas dan 
menjalin hubungan sehingga timbul struktur sosial, stratifikasi sosial, diferensiasi dan sebagainya. Dengan kompleksitas yang dimilikinya, masyarakat bersifat dinamis. Masuknya pengaruh dari masyarakat lain, perubahan lingkungan, penemuan bidang ilmu pengetahuan dan teknologi, menyebabkan terjadinya perubahan sosial dalam masyarakat.

Perubahan sosial juga meliputi perubahan dalam distribusi kelompok usia, tingkat pendidikan rata-rata, tingkat kelahiran penduduk, penurunan rasa kekeluargaan dan informalitas antar tetangga, dan perubahan peran suami dalam keluarga yang dari sebagai atasan menjadi mitra istri dalam menjalankan tugas-tugas dalam keluarga.

Islam adalah agama yang menyediakan perangkat nilai, norma, dan aturan yang meliputi segenap aspek kehidupan manusia, termasuk dalam hidup bermasyarakat. Agama merupakan salah satu faktor yang menyebabkan terjadinya perubahan sosial. Dalam Islam, para penganutnya sudah mencari Tuhan dalam sejarah. Seorang 
muslim harus menyelamatkan sejarah sehingga urusan masyarakat tidak menghalangi kehidupan spiritualitas.

Konsep perubahan sosial menurut pandangan Islam dijelaskan dalam surat Ar-Ra'd ayat 11:

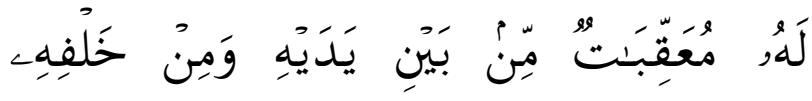

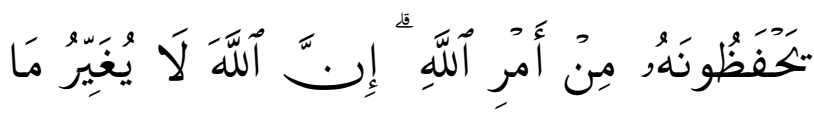

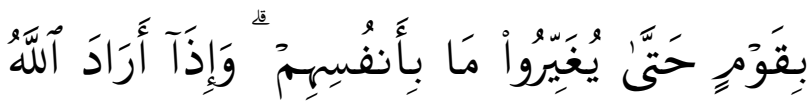

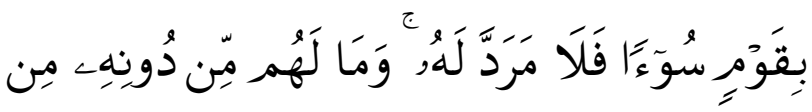

$$
\text { ǵ }
$$

"Bagi manusia ada malaikat-malaikat yang selalu mengikutinya bergiliran, di muka dan di belakangnya, mereka menjaganya atas perintah Allah. Sesungguhnya Allah tidak merubah keadaan sesuatu kaum sehingga mereka merubah 
keadaan yang ada pada diri mereka sendiri. Dan apabila Allah menghendaki keburukan terhadap sesuatu kaum, maka tak ada yang dapat menolaknya; dan sekali-kali tak ada pelindung bagi mereka selain Dia”.

Dari ayat tersebut, perubahan sosial mengandung karakteristik otonomi masyarakat. Masyarakat diberikan hak otonomi oleh Allah untuk menjalankan proses sosial. Sebuah masyarakat harus mampu beradaptasi dan mempertahankan keberadaannya serta berkembang dalam zaman dan alam tertentu. Individu-individu atau kelompok harus bisa menjalin relasi yang terintegrasi satu sama lain dengan berpedoman pada norma masyarakat yang berlaku sehingga tercipta keseimbangan hidup bermasyarakat.

Allah memberikan kepercayaan kepada suatu kaum untuk berupaya mengubah keadaannya ke arah yang lebih baik secara lahiriah maupun bathiniah. Allah tidak menghendaki suatu kaum yang bersikap pasif menerima keadaan, sebalikya 
Allah menganjurkan kepada kita untuk selalu bekerja keras dan berperan aktif dalam sebuah masyarakat.

Dapat di simpulkan surat Ar-Ra'd ayat 11 memberikan pemahaman tentang konsep dasar perubahan sosial dalam pandangan Islam, sebagai berikut:

1. Allah memiliki kebebasan bertindak secara mutlak

2. Manusia memiliki kebebasan bertindak terbatas

3. Perubahan digerakkan dari dalam diri manusia sendiri

4. Perubahan keadaan manusia dilakukan Tuhan sebagai hasil perubahan diri manusia itu sendiri.

\section{RANGKUMAN}

1. Ilmu sosial dan politik dalam perspektif Islam adalah sebagai pedoman hidup manusia sebagai khalifah di muka bumi Allah dalam hubungannya dengan manusia yang lain 
sehingga tercipta masyarakat islami yang tata aturannya berdasarkan hukum Islam.

2. Teori keadilan dalam Islam mengandung makna menenmpatkan sesuatu pada tempatnya, memberikan sesuatu yang menjadi haknya secara seimbang dan membebankan sesuai daya pikul seseorang.

3. Konsep perubahan sosial dalam pandangan Islam, diantaranya Allah memiliki kebebasan bertindak secara mutlak, manusia memiliki kebebasan bertindak terbatas, perubahan digerakkan dari dalam diri manusia sendiri serta perubahan keadaan manusia dilakukan Tuhan sebagai hasil perubahan diri manusia itu sendiri.

\section{EVALUASI}

Untuk memperdalam pemahaman mengenai materi diatas, kerjakanlah latihan berikut!

1. Jelaskan hakikat ilmu sosial dan politik dalam perspektif Islam! 
2. Diskusikan teori-teori lain tentang ilmu sosial dan politik dalam Islam!

3. Carilah dan temukan ayat-ayat al-Qur'an dan hadist yang relevan dengan penerapan ilmu sosial dan politik!

\section{E. DAFTAR PUSTAKA}

Ahmad, Mumtaz. 1996. Masalah-masalah Teori Politik Islam. Bandung: Mizan.

Ahmad, Zainal Abidin. 1998. Ilmu Politik Islam. Jakarta: Bulan Bintang.

Departemen Agama RI. 2004. Al-Qur'an dan Terjemah. Bandung: . Al-Jumanatul 'Ali.

Rahman, Fazlur. 1996. Tema Pokok AlQur'an. Bandung: Pustaka.

Shihab, M. Quraish. 1998. Wawasan AlQur'an. Bandung: Mizan. 


\section{BAB IX}

\section{ETIKA ISLAM DALAM PENERAPAN ILMU SOSIAL DAN POLITIK}

\section{A. Pendahuluan}

Dalam kehidupan manusia tidak bisa terlepas dari nilai etika. Peran etika sangat besar dalam perubahan kehidupan manusia. Dalam Islam terlihat jelas pada risalah kenabian tentang anjuran untuk menyempurnakan akhlak atau perilaku manusia agar menjadi lebih baik dan mulia.

Kehidupan di masa sekarang banyak diwarnai dengan dekadensi moral. Kepentingan-kepentingan yang cenderung kapitalis atau masuknya budaya asing menjadi salah satu penyebabnya. Etika Islam menjadi pedoman untuk memperbaiki moral generasi penerus bangsa sehingga menjadi generasi Islami. Etika sangat menentukan tingkah laku manusia. Karena etika merupakan kumpulan asas atau nilai yang berkenaan dengan akhlak, nilai mengenai benar dan salah yang dianut suatu golongan atau masyarakat. Etika juga bisa diartikan studi tentang tingkah laku manusia yang 
menyelidiki manfaat atau kebaikan seluruh tingkah laku manusia.

Dalam penerapan ilmu sosial dan politik, peran etika Islam sangat diperlukan untuk mengkaji nilainilai Islam didalamnya. Dalam menjalin hubungan sosial antara individu dengan individu yang lain akan berjalan seimbang jika dibentengi dengan nilai-nilai etika Islam sebagai petunjuk jalan untuk melakukan apa yang seharusnya diperbuat. Etika yang dianjurkan dalam ajaran Islam adalah yang tercantum di dalam Al-Qur'an dan Sunnah dengan mengambil teladan dari Rasulullah yang dinyatakan sebagai manusia yang paling sempurna akhlaknya.

Melalui pembahasan dalam etika islam dalam penerapan ilmu sosial dan politik, mahasiswa diharapkan mampu memahami lebih lanjut mengenai ilmu sosial politik dan kemanusiaan, mampu mendeskripsikan ilmu sosial politik untuk kemaslahatan hidup dan mampu menganalisis ayatayat Al-Qur'an dan hadist yang relevan dengan etika ilmu sosial dan politik. 


\section{B. Penyajian Materi}

\section{Ilmu Sosial Politik dan Kemanusiaan}

Dalam mencapai tujuan yang tinggi, Islam memerintahkan pencarian ilmu dan pengetahuan, melepaskan akal manusia dari belenggu taqlid dan mendorong manusia untuk menggali rahasiarahasia Allah yang tersebar dalam ciptaanNya; bumi, langit, air dan udara, untuk memperkuat keimanan kepada Allah dan agar manusia berbahagia dan mendayagunakan apa yang diketahui dari rahasia-rahasia alam alam yang diciptakan Allah untuk manusia di dalam kehidupannya.

Manusia, menurut Al-Qur'an, memiliki potensi untuk meraih ilmu dan mengembangkannya dengan seizin Allah. Karena itu, bertebaran ayat yang memerintahkan manusia berbagai cara untuk mewujudkan hal tersebut. Berkali-kali pula Al-Qur'an menunjukkan betapa tinggi kedudukan orang yang berpengetahuan. Sebagaimana dalam firmanNya surat AlMujadilah ayat 11: 


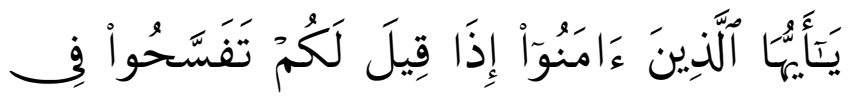

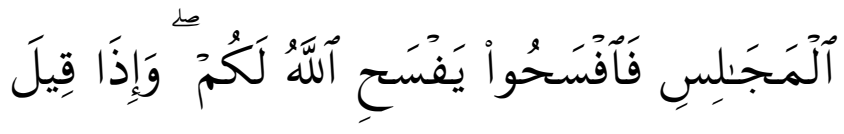

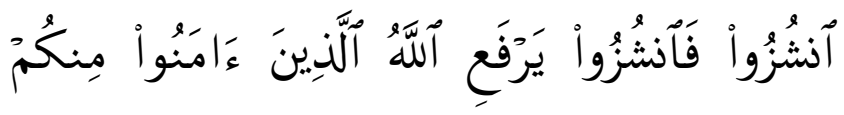

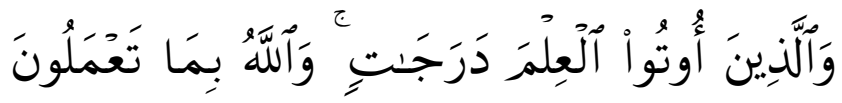

$$
\begin{aligned}
& \text { خَبِيرن }
\end{aligned}
$$

“Wahai orang-orang yang beriman! Apabila dikatakan kepadamu, "Berilah kelapangan di dalam majelis-majelis," maka lapangkanlah, niscaya Allah akan memberi kelapangan untukmu. Dan apabila dikatakan, "Berdirilah kamu," maka berdirilah, niscaya Allah akan mengangkat derajat orang-orang yang beriman di antaramu dan orang-orang yang diberi ilmu beberapa derajat.

Dan Allah Maha 
teliti

$$
\begin{array}{rrr}
\text { apa yang } & \text { kamu kerjakan. } \\
\text { (Q.S. Al-Mujadilah }: 11)
\end{array}
$$

Dalam penataan kehidupan manusia, Islam menganjurkan kepada kita untuk memahami ilmu sosial. Islam tidak membiarkan manusia membuat syariat untuk dirinya sendiri dan tidak mengikatnya dengan syariat tertentu namun Islam meletakkan hukum-hukum dan dasar-dasar syariat dalam pedoman hubungan kemanusiaan.

Islam memandang manusia sebagai individu yang memiliki personalitas independen yang mempunyai hak melakukan sesuatu yang mengandung kemaslahatan baginya dan bermakna bagi kehidupannya tanpa merongrong hak orang lain. Namun dalam waktu yang sama juga memandangnya sebagai anggota atau bagian dalam bangunan masyarakat yang mempunyai kewajiban membantu kemanusiaan dengan melakukan pembimbingan bagi yang sesat, membantu yang lemah, mencegah yang munkar, serta ikut terlibat dalam setiap hal yang dapat meningkatkan kebersamaan kehidupan manusia. 
Manusia merupakan makhluk yang sangat sempurna dibanding dengan makluk-makluk ciptaan Allah yang lain di muka bumi ini.Dengan dibekali pembawaan dari Allah SWT berupa akal untuk mengelola keseimbangan alam ini.Tujuan Allah menciptakan manusia itu sendiri adalah sebagai wakil atau kholifah secara langsung di muka bumi ini agar tujuan hidup menjadi serasi, selaras, seimbang. Manusia mendapatkan ilmu melalui perantaraan kalam yang diciptakan oleh Allah.Hal ini sesuai dengan firman Alloh surat Al-Alaq Ayat 1-5 sebagai berikut :

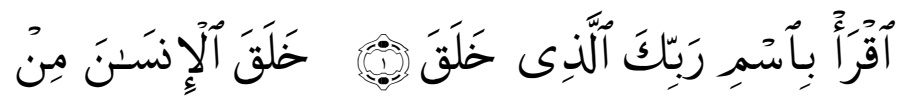

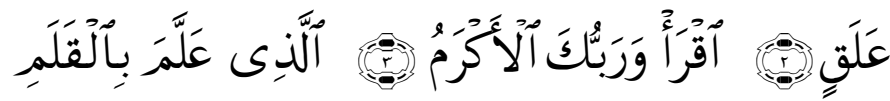

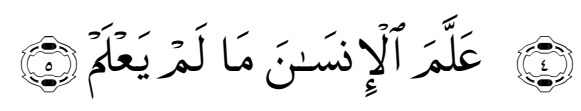

Artinya: "Bacalah dengan (menyebut) nama Tuhanmu yang Menciptakan, Dia telah menciptakan manusia dari segumpal darah. 
Bacalah, dan Tuhanmulah yang Maha pemurah, Yang mengajar (manusia) dengan perantaran kalam, Dia mengajar kepada manusia apa yang tidak diketahuinya."

Dengan dibekali hal diatas maka fungsi manusia terhadap ilmu adalah menemukan, mengembangkan, menciptakan, kemudian mengevaluasi terhadap ilmu yang didapatnya melalui proses berpikir yang alami dan sistematis. dengan pemikiran seperti itu manusia bisa membagi atau memetakan suatu ilmu degan spesifikasi tertentu yang berkembang saat ini dan sudah dimanfaatkan oleh manusia. Jadi, jelaslah bahwa ilmu sosial politik dan kemanusiaan mempunyai hubungan yang tidak terpisahkan. Ilmu sosial politik menjadi pedoman bagi manusia menjalankan perannya dalam kehidupan bermasyarakat, sedangkan manusia dituntut untuk mengembangkan keilmuan itu demi perkembangan ilmu sosial politik. 


\section{Ilmu Sosial Politik untuk Kemaslahatan Hidup}

Ilmu sosial politik pada dasarnya mengatur kemaslahatan hidup. Hasil dari kegiatan keilmuannya memberikan pedoman kepada manusia untuk bertindak dalam kehidupan bermasyarakat dan bernegara. Banyaknya kejadian yang mengindikasikan terjadinya dekadensi moral umat manusia dewasa ini, semakin menyadari bahwa peran ilmu sangat penting demi membentuk etika, moral, norma dan kesusilaan.

Dengan hadirnya kemajuan ilmu sosial politik, telah membimbing manusia pada kemaslahatan umat. Perkembangan ilmu sosial politik akan bermanfaat bagi manusia yakni memperbaiki kualitas hidup manusia dengan memperhatikan kodrat manusia dan berbagai kemudahan dalam berkomunikasi. Hal ini sejalan dengan manfaat ilmu bahwa pengetahuan merupakan kekuasaan yang dapat dipakai untuk kemaslahatan manusia. 
Dalam menegakkan kemaslahatan, bisa terlihat dalam prinsip-prinsip dasar sosial politik dalam Islam:

a. Musyawarah

Musyawarah dilaksanakan dalam upaya untuk menentukan keputusan dalam beberapa masalah yang berkaitan dengan hajat hidup orang banyak. Diantaranya, berkenaan dengan pemilihan para ulil amri, penentuan jalan dan cara pelaksanaan undang-undang, serta jalan bagi penentu perkara-perkara baru yang timbul di kalangan umat melalui proses ijtihad. Pentingnya musyawarah dalam Islam adalah upaya untuk mencari sebuah pandangan objektif dalam sebuah perkara, sehingga pengambilan keputusannya dapat dilakukan secara bulat atau dengan resiko yang relatif kecil.

Dalam tradisi Islam, dikenal juga upaya pengambilan keputusan secara bersama-sama dan berdasarkan suara terbanyak, cara ini disebut dengan 
Ijma’. Sebagai

bagian dari

upaya musyawarah dalam ajaran Islam yang dipentingkan adalah adanya jiwa

persaudaraan ataupun keputusan

yang

didasarkan atas pertimbangan nurani dan akal sehat secara bertanggung jawab terhadap suatu masalah yang menyangkut kemaslahatan bersama dan bukan atas pertimbangan sesaat.

b. Keadilan

Dalam pelaksanaannya yang luas, prinsip keadilan yang terkandung dalam sistem politik Islam merangkum segala jenis hubungan yang berlaku dalam kehidupan manusia, termasuk keadilan di antara rakyat dan pemerintah, di antara dua pihak yang bersengketa serta masalah lain yang menuntut keadilan. Pemeliharaan terhadap keadilan merupakan prinsip nilai-nilai sosial yang utama karena dengannya dapat dikukuhkan kehidupan untuk kemaslahatan. 
c. Kebebasan

Prinsip kebebasan selalu ditegakkan pada sistem politik dan pemerintahan Islam. Kebebasan yang dipelihara adalah kebebasan yang makruf yang sesuai dengan Al-Quran dan Hadist, sehingga terjalin kemaslahatan hidup.

d. Silaturrahmi

Dalam kehidupan bermasyarakat terdapat perbedaan ras, bahasa, wilayah maupun perbedaan materialistis lainnya yang memunculkan kecenderungan memecah belah kesatuan. Dengan memahami ilmu sosial, segala persoalan yang menimbulkan perselisihan bisa dibentengi dengan kaidahkaidah umum demi memperkuat kesatuan bermasyarakat.

\section{Ayat-Ayat Al-Qur'an dan Hadist yang relevan dengan Etika Ilmu Sosial dan Politik}

Secara terminologi, etika sosial berarti sebuah tatanan yang mengatur tentang perilaku seseorang terkait pergaulan dengan lingkungan. Aturan 
tentang etika sosial bersifat normatif sehingga tidak diatur dalam hukum formal. Etika sosial dalam Islam harus berlandaskan pada cita-cita keadilan dan kebebasan sesuai AlQuran dan Hadist bagi individu untuk melakukan kebaikan sosial. Etika sosial Islam adalah sebuah pandangan moralitas agama yang mengarahkan manusia untuk berbuat baik antar sesamanya agar tercipta masyarakat yang baik dan teratur. Persoalan etika politik adalah sesuatu yang sangat penting dalam Islam. Karena politik dipandang sebagai bagian dari ibadah, yang harus didahului dengan niat karena Allah ta'ala dan menyangkut hubungan antar manusia.

Ayat-Ayat Al-Qur'an dan Hadist yang relevan dengan Etika Ilmu Sosial dan Politik:

- Dalam Islam, musyawarah yang merupakan etika dalam berpolitik tidak hanya dinilai sebagai prosedur pengambilan keputusan yang direkomendasikan, tetapi juga merupakan tugas keagamaan. Seperti yang telah dilakukan oleh Nabi dan diteruskan oleh khulafaur 
rasyidin. Firman Allah Swt dalam QS. Al Imran ayat 159:

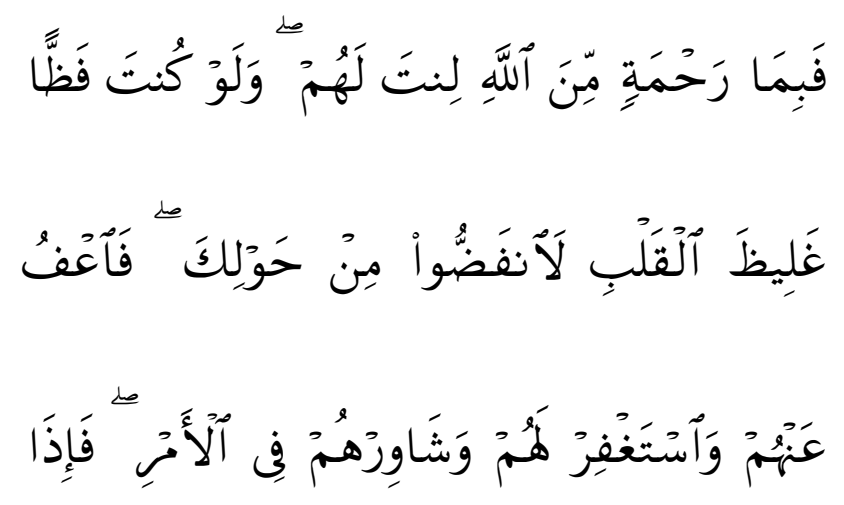

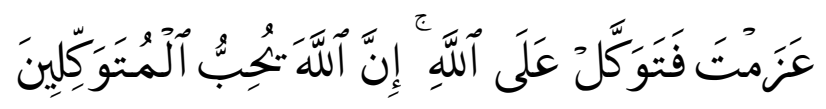

"Maka disebabkan rahmat dari Allah SWT lah kamu berlaku lemah lembut terhadap mereka, sekiranya kamu bersikap keras dan berhati kasar tentulah mereka menjauhkan diri dari sekelilingmu. Karena itu maafkanlah mereka, mohonlah ampunan bagi mereka, dan bermusyawarahlah dengan mereka dalam urusan itu, dan apabila kamu telah 
membulatkan tekad maka berdakwahlah kepada Allah SWT, sesungguhnya Allah menyukai orang-orang yang bertawakkal kepadaNya”. (QS. Ali Imran:159)

- Dalam ajaran Islam menganjurkan adanya persamaan antar sesama umat. Islam tidak mengenal adanya perbedaan suku bangsa, strata sosial, harta dan kedudukan serta perlakuan diskriminatif atas dasar keduniawian. Allah SWT dalam firmanNya surat Al-Hujurat ayat 13 menegaskan bahwa yang membedakan hanyalah kualitas ketakwaan seseorang.

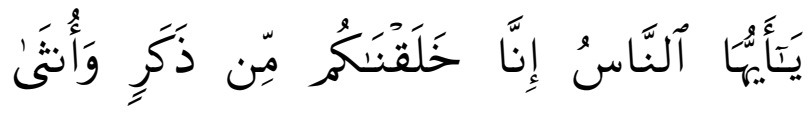

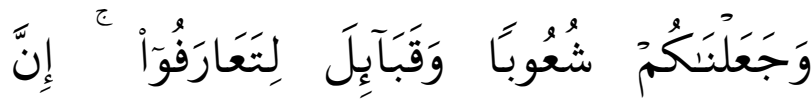

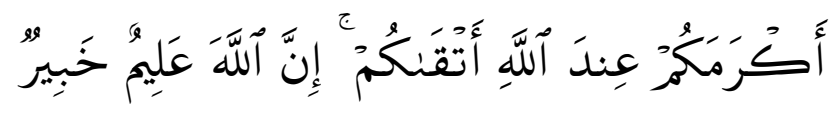


"Hai manusia, Sesungguhnya Kami menciptakan kamu dari seorang laki-laki dan seorang perempuan dan menjadikan kamu berbangsa - bangsa dan bersuku-suku supaya kamu saling kenal-mengenal. Sesungguhnya orang yang paling mulia diantara kamu disisi Allah ialah orang yang paling taqwa diantara kamu. Sesungguhnya Allah Maha mengetahui lagi Maha Mengenal."

- Al-Quran menetapkan bahwa salah satu sendi kehidupan bermasyarakat adalah keadilan. Tidak lebih dan tidak kurang. Berbuat baik melebihi keadilan, seperti memaafkan yang bersalah atau memberi bantuan kepada yang malas akan dapat menggoyahkan sendi kehidupan bermasyarakat. Islam memerintahlan untuk menjadi manusia yang ertanggungjawab dan bertindak sesuai dengan kontrol sosialnya sehingga keharmonisan dan keadilan hidup akan terwujud. Allah SWT berfirman dalam surat Al-Maidah ayat 8: 


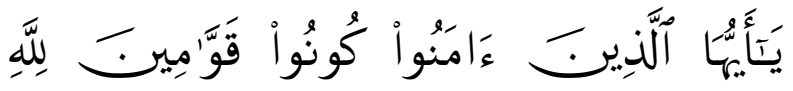

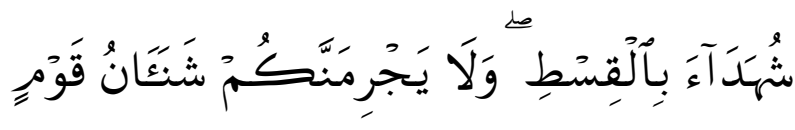

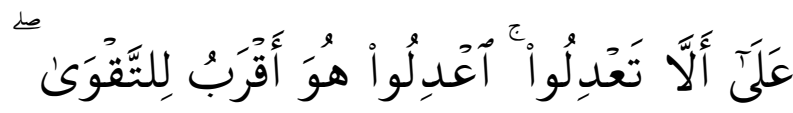

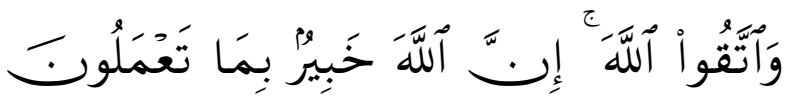

"Hai orang-orang yang beriman hendaklah kamu jadi orang-orang yang selalu menegakkan (kebenaran) karena Allah, menjadi saksi dengan adil. Dan janganlah sekali-kali kebencianmu terhadap sesuatu kaum, mendorong kamu untuk berlaku tidak adil. Berlaku adillah, karena adil itu lebih dekat kepada takwa. Dan bertakwalah kepada Allah, sesungguhnya Allah Maha Mengetahui apa yang kamu kerjakan." 
Untuk membentengi jalan bagi kehidupan kemanusiaan yang lebih baik, Islam menerapkan sistem keadilan dan musyawarah. Dua sistem yang menjadi dasar hukum dan menjelaskan sumber-sumber perundangundangan yang dapat dijadikan landasan dalam kehidupan. Allah berfirman dalam Surat AlNisa' ayat 58:

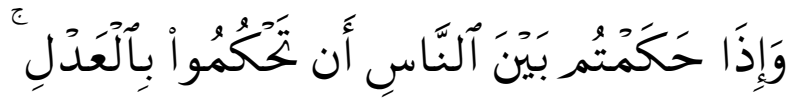

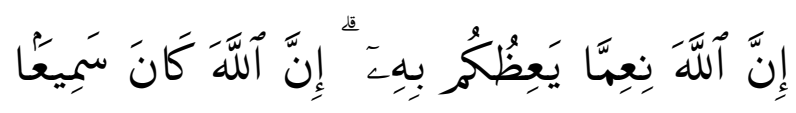

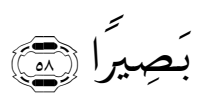

"Sesungguhnya Allah menyuruh kamu menyampaikan amanat kepada yang berhak menerimanya, dan menyuruh kaтu apabila menetapkan hukum di antara manusia supaya 
kamu menetapkan dengan adil. Sesungguhnya Allah memberi pengajaran yang sebaikbaiknya kepadamu. Sesungguhnya Allah Maha Mendengar lagi Maha Melihat."

- Dalam mengemban amanah dari Allah SWT yakni sebagai khalifah dimuka bumi, manusia tidak diciptakan sekedar untuk permainan. Tetapi untuk melaksanakan sebuah tugas berat dan harus dipertanggungjawabkan keberhasilan atau kegagalannya, karena baik Tuhan maupun manusia telah mengambil resiko yang besar dalam memikul tugas sebagai khalifah. Umat manusia diberikan kebebasan untuk menentukan jalan mana yang mereka tempuh. Namun kebebasan yang dipelihara oleh Islam adalah kebebasan yang mengarah kepada ma'ruf dan kebaikan. Etika ini menjadi pedoman ilmu politik dalam bertindak. Sebagaimana Allah berfirman dalam surat Al-An'am ayat 164: 


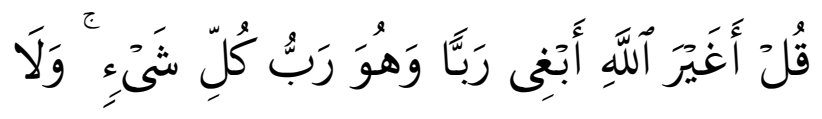

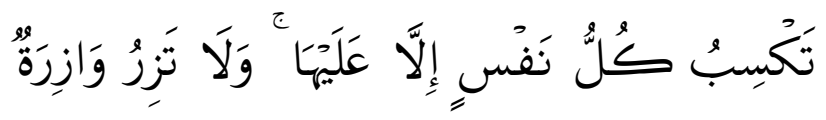

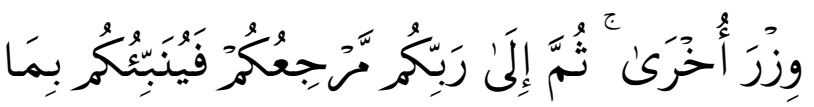

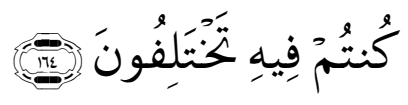

"Katakanlah: "Apakah aku akan mencari Tuhan selain Allah, padahal Dia adalah Tuhan bagi segala sesuatu. Dan tidaklah seorang membuat dosa melainkan kemudaratannya kembali kepada dirinya sendiri; dan seorang yang berdosa tidak akan memikul dosa orang lain. Kemudian kepada Tuhanmulah kamu kembali, dan akan diberitakan-Nya kepadamu apa yang kamu perselisihkan".

- Dalam menerapkan politik yang syar'i, terdapat kaidah yang menjadi etika islam dalam kehidupan berpolitik. Diantaranya 
adalah kejujuran, amanah, tidak mengandung unsur syirik, tidak berambisi dalam jabatan dan tolong menolong. Sebagaimana hadist yang diriwayatkan Al-Imam Al- Bukhari (no. 7146) dan Al-Imam Muslim (no. 1652) mengenai larangan berambisi dalam jabatan, Rasulullah bersabda:

"Wahai Abdurrahman bin Samurah, janganlah engkau meminta kepemimpinan. Karena sungguh, jika engkau diberi kedudukan tanpa memintanya, niscaya engkau akan ditolong (Allah) atas kedudukan (yang ada padamu). Sedangkan jika kedudukan tersebut diperoleh dari hasil meminta, engkau bakal dibebani kedudukan tersebut (tidak ditolong Allah)."

- Dalam ilmu sosial dan politik, tolong menolong haruslah dalam hal kebajikan. Bukan sekedar koalisi apalagi oposisi untuk berbagi kekuasaan (materi). Sebagaimana firmanAllah SWT dalam QS. Al-Maidah ayat 2: 


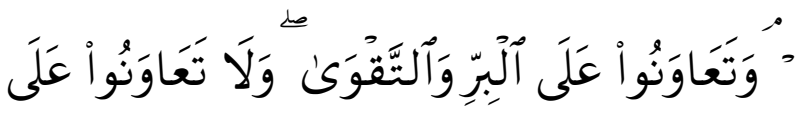

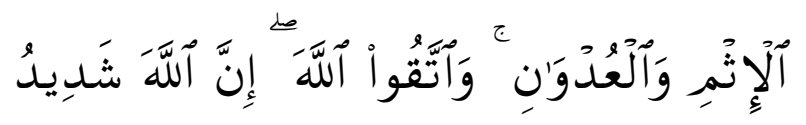

$$
\begin{aligned}
& \text { آلَّعَقابِ }
\end{aligned}
$$

"Dan tolong-menolonglah kalian dalam (mengerjakan) kebajikan dan takwa, dan janganlah tolong-menolong dalam berbuat dosa dan pelanggaran. Bertakwalah kalian kepada Allah, sesungguhnya Allah amat berat siksa-Nya." (QS, Al-Maidah: 2)

- Dalam hal etika sosial, Allah menjelaskan dalam firmanNya surat Al-Hujurat ayat 11mengenai tatakrama sosial:

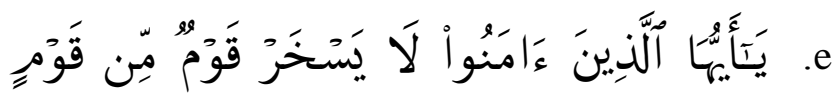

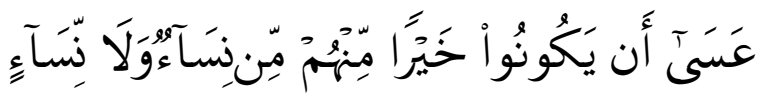



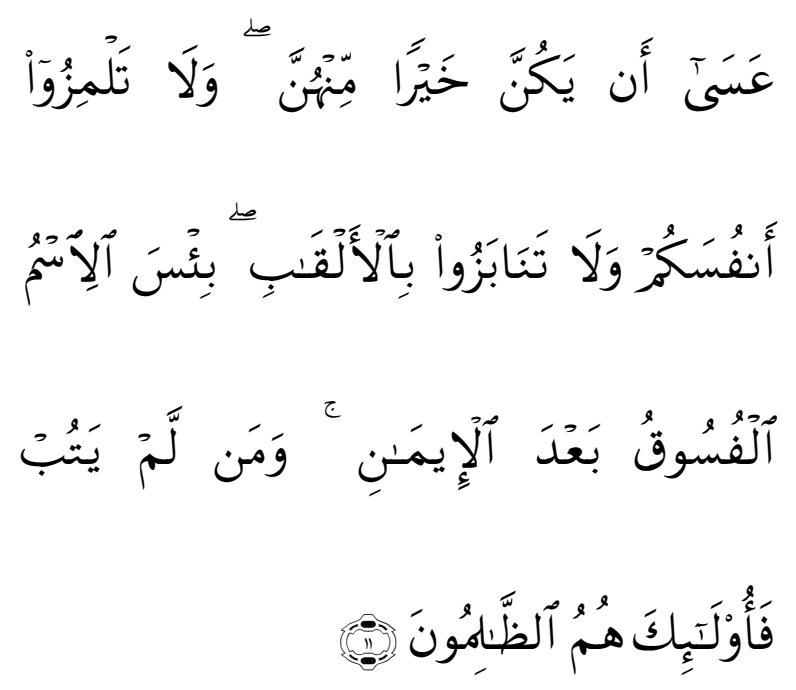

"Hai orang-orang yang beriman, janganlah suatu kaum mengolok-olokan kaum yang lain (karena) boleh jadi mereka (yang diolok-olokkan) lebih baik dari mereka (yang mengolok-olokkan) dan janganlah pula wanita-wanita mengolok-olokkan) wanita-wanita lain (karena) boleh jadi wanitawanita (yang diperolok-olokkan) lebih baik dari pada wanita-wanita (yang mengolok-olokkan) dan janganlah kamu mencela dirimu sendiri dan janganlah kamu panggil memanggil dengan gelargelar yang buruk. Seburuk-buruk panggilan ialah (panggilan) yang buruk sesudah iman, dan 
barangsiapa yang tidak bertaubat, maka mereka itulah orang-orang yang zalim."

- Ilmu sosial sangat mengindahkan prinsip-prinsip yang menjadi dasar kehidupan. Islam memperkuatnya dengan memelihara sejumlah sifat baik dalam menyeimbangkan hubungan kemanusiaan dengan memberikan pedoman tentang tatakrama individu dan kelompok. Manusia harus bisa melepaskan sifat congkak, bangga dan besar diri serta menghindarkan prasangka-prasangka jelek dan bisikan - bisikan hati yang buruk. Mengenai hal ini Allah SWT berfirman:

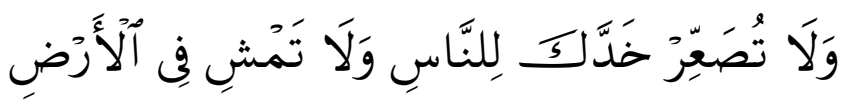

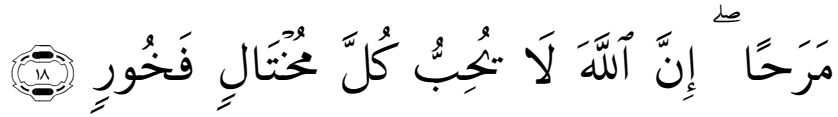



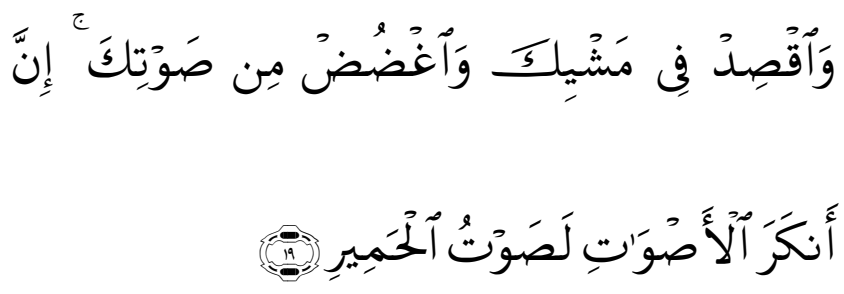

"dan janganlah kamu memalingkan muka dari manusia (karena sombong) dan janganlah kamu berjalan di muka bumi dengan angkuh. Sesungguhnya Allah tidak menyukai orang-orang yang sombong lagi membanggakan diri. Dan sederhanakanlah kamu dalam berjalan dan lunakkanlah suaramu. Sesungguhnya seburuburuk suara ialah suara keledai. (QS. Luqman: 18-19)

Dalam Surat Al-Hujurat ayat 12 juga di jelaskan:
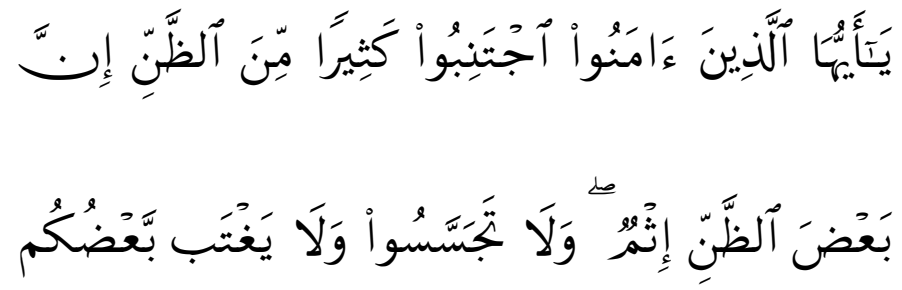


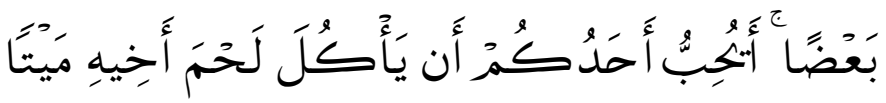

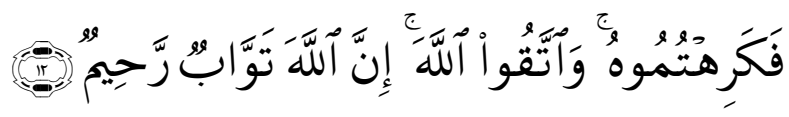

"Hai orang-orang yang beriman, jauhilah kebanyakan dari prasangka, sesungguhnya sebagaian prasangka itu adalah dosa dan janganlah kamu mencari-cari kesalahan orang lain dan janganlah sebagian kamu menggunjing sebagian yang lain. Sukakah salah seorang diantara kamu memakan daging saudaranya yang sudah mati? Maka tentulah kamu merasa jijik kepadanya. Dan bertakwalah kepada Allah, Sesungguhnya Allah Maha Penerima Taubat lagi Maha Penyayang”.

- Dalam hal ilmu politik, Islam memerintahkan pembelaan atas keberadaan negara dan melindunginya dari usaha -usaha intervensi musuh serta mempersiapkan kekuatan dan pembelaan secukupnya dengan berbekal ilmu 
politik. Hal ini sesuai dengan firman Allah SWT surat Al-Anfal ayat 60:

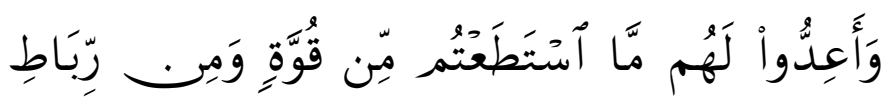

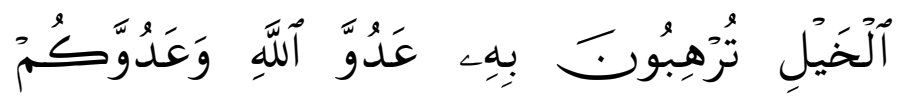

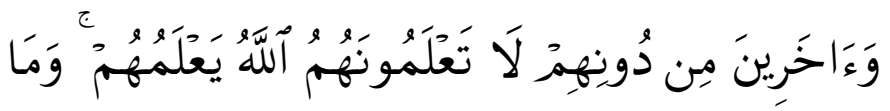

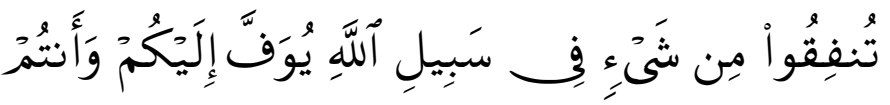

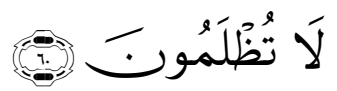

"Dan siapkanlah untuk menghadapi mereka kekuatan apa saja yang kamu sanggupi dan dari kuda-kuda yang ditambat untuk berperang (yang dengan persiapan itu) kamu menggentarkan musuh Allah, тиsuhmu dan orang-orang selain mereka yang kamu tidak mengetahuinya, sedang Allah mengetahuinya. Apa saja yang kamu nafkahkan di jalan Allah niscaya akan dibalasi 
dengan cukup kepadamu dan kamu tidak dianiaya." (QS. Al-Anfal:60)

\section{RANGKUMAN}

1. Hubungan ilmu sosial politik dan kemanusiaan saling terkait. Ilmu sosial politik menjadi pedoman bagi manusia menjalankan perannya dalam kehidupan bermasyarakat, sedangkan manusia dituntut untuk mengembangkan keilmuan itu demi perkembangan ilmu sosial politik.

2. Dengan hadirnya kemajuan ilmu sosial politik, telah membimbing manusia pada kemaslahatan umat. Perkembangan ilmu sosial politik akan bermanfaat bagi manusia yakni memperbaiki kualitas hidup manusia dengan memperhatikan kodrat manusia dan berbagai kemudahan dalam berkomunikasi. Hal ini sejalan dengan manfaat ilmu bahwa pengetahuan merupakan kekuasaan yang dapat dipakai untuk kemaslahatan manusia. 


\section{EVALUASI}

Untuk memperdalam pemahaman Anda mengenai materi diatas, kerjakanlah latihan berikut!

1. Jelaskan hubungan ilmu Sosial politik dengan kemanusiaan?

2. Apa yang dimaksud dengan ilmu sosial politik untuk kemaslahatan hidup? Jelaskan!

3. Carilah ayat Al-Qur'an dan hadist lainnya yang relevan etika ilmu sosial dan politik serta bagaimana anda menganalisis dalil tersebut!

\section{E. DAFTAR PUSTAKA}

Ahmad, Zainal Abidin. 1998. Ilmu Politik Islam. Jakarta: Bulan Bintang.

Departemen Agama RI. 2004. Al-Qur'an dan

Terjemah. Bandung: . Al-Jumanatul 'Ali.

Rahman, Fazlur. 1996. Tema Pokok AlQur'an. Bandung: Pustaka.

Shihab, M. Quraish. 1998. Wawasan Al-Qur'an. Bandung: Mizan.

Syaltut, Mahmud. 1987. Pesan Kepada Umat Islam. Jakarta: Darul Ulum Press. 
Tahqiq, Nanang. 2004. Politik Islam. Jakarta: Prenada Media, 


\section{BAB X}

\section{PRINSIP DAN AJARAN ISLAM DALAM PENERAPAN ILMU KOMUNIKASI}

\section{A. Pendahuluan}

Melalui kitabNya Al-Qur'an, Allah SWT mengajarkan betapa pentingnya komunikasi bagi umat manusia. Komunikasi adalah pengiriman dan penerimaan pesan antara dua orang atau lebih. Dengan berkomunikasi akan membawa kepada perubahanperubahan, baik perubahan perilaku, cara hidup bermasyarakat, serta perubahan nilai.

Dalam ajaran Islam, penerapan ilmu komunikasi disamping untuk mewujudkan hubungan secara vertikal dengan sang Kholiq yang tercermin melalui ibadah, juga untuk menegakkan hubungan secara horizontal dengan sesama manusia yang terwujud melalui hubungan sosial atau muamalah. Agar komunikasi dapat berjalan dengan baik dan efektif, Islam memberikan kaidah atau prinsip dalam berkomunikasi. Kaidah komunikasi Islam ini menjadi panduan bagi kaum muslimin dalam berinteraksi dengan sesama baik secara lisan maupun tulisan. 
Untuk mempelajari lebih mendalam mengenai prinsip dan ajaran Islam dalam penerapan ilmu komunikasi, akan diuraikan tentang jenis-jenis komunikasi, sehingga diharapkan mahasiswa mampu memahami komunikasi transendental, komunikasi politik, komunikasi transaksional, komunikasi verbal dan komunikasi non verbal.

\section{B. Penyajian Materi}

\section{Komunikasi Transendental}

Komunikasi transendental merupakan komunikasi langsung tanpa pembatas antara manusia dengan Tuhan. Hal ini dimaksudkan untuk mengharap ridha Allah SWT dan selamat dunia akhirat. Komunikasinya bisa berupa kegiatan yang dilakukan manusia dalam beribadah. Misalkan shalat, puasa, tadarrus, zakat, dan kegiatan ibadah lainnya yang secara tidak sadar, kita telah berkomunikasi dengan sang pencipta.

Untuk menjadi seorang komunikan yang baik dalam komunikasi transendental, harus mematuhi perintah dan menjauhi laranganNya yang telah 
digariskan oleh Allah SWT dalam Al-Qur'an. Pada saat shalat, Jika kita mempunyai keyakinan yang kuat bahwa kita sedang diperhatikan dan mendengar doa kita, maka setiap gerakan shalat kita akan menjadi khusuk, hati menjadi tenang dan serasa jiwa sangat dekat dengan sang pencipta.

Selain menjadi komunikan transendental yang efektif, kita juga sebagai partisipan komunikasi transendental yang efektif. Ketika menyaksikan keindahan alam, yang nampak bukan hanya sekedar fenomena alam, tetapi sebagai perwujudan kebesaran dan kekuasaan Allah SWT, sehingga menambah keimanan dan ketakwaan kepada Allah SWT dengan memperbanyak doa dan dzikir.

Komunikasi transendental memberikan kekuatan hubungan manusia dengan Tuhan. Karena pada hakikatnya manusia tidak mampu untuk memnsyukuri Allah secara sempurna, baik dalam bentuk kalimat-kalimat pujian apalagi dalam bentuk perbuatan. Karena itu dalam surat Al-Ahqaf ayat 15 menjelaskan betapa orang- 
orang yang dekat kepadaNya sekalipun, tetap memohon untuk dibimbing, diilhami dan diberi kemampuan untuk dapat mensyukuri nikmatnya.

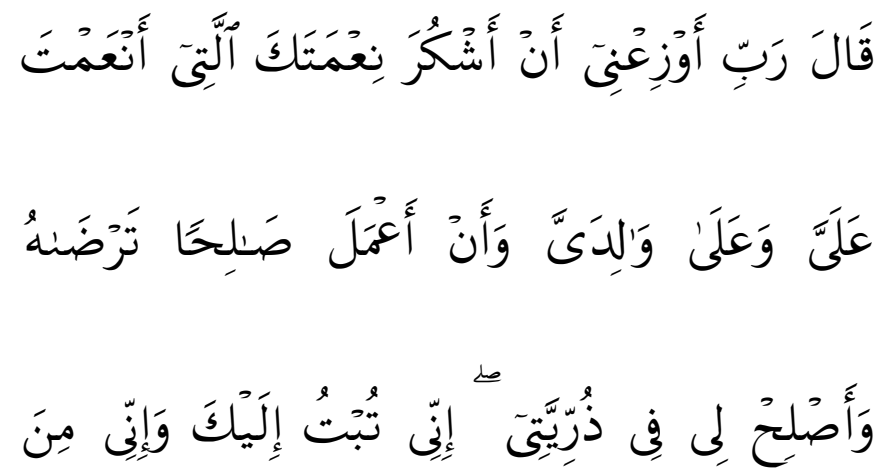

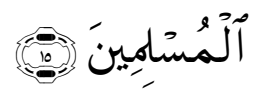

" Ia berdoa, " Wahai Tuhanku, tunjukilah aku unutk mensyukuri nikmatMu yang telah Engkau berikan kepadaku dan kepada ibu bapakku, dan supaya aku dapat berbuat amal shaleh yang Engkau ridhai, berilah kebaikan kepadaku dengan (memberi kebaikan) kepada ank cucuku. Sesungguhnya aku bertobat kepada Engkau dan sesungguhnya aku termasuk orang-orang yang berserah diri” (QS. Al-Ahqaf:15). 
Salah satu upaya penghambaan kita kepada Allah SWT untuk memperkuat komunikasi transendental dalam bentuk perbuatan adalah shalat. Karena shalat merupakan ibadah multi segi. Mengerjakannya secara teratur mengingatkan kaum muslimin berulangkali sehari semalam akan hubungannya dengan penciptaNya. Ingat kepadaNya dan memujaNya dengan berkonsentrasi penuh adalah bentuk komunikasi yang bertujuan untuk menjaga diri dari lupa mengingat kepunyaan siapakah dirinya, bukan milik dirinya sendiri bahkan milik orang lain yang terdekat dengannya, melainkan ia adalah hamba Allah SWT.

\section{Komunikasi Politik}

Dalam sistem politik, fungsi komunikasi politik sangatlah penting. Semua informasi politik diperoleh melalui komunikasi politik. Komunikasi politik bisa diartikan seluruh proses transmisi, pertukaran, dan pencairan informasi yang dilakukan oleh partisipan dalam kegiatan-kegiatan 
politik yang terlembaga. Konsep kajian dalam komunikasi politik, diantaranya adalah:

a. Komunikator

Yaitu Partisipan yang menyampaikan informasi. Islam mengajarkan kepada umatnya agar dalam perannya sebagai komunikator atau penyampai pesan harus amanah dan melarang memiliki kecenderungan melebih-lebihkan posisi diri dan tindakan suatu kelompok dibandingkan kelompok lain sehingga terjadi ketidakakuratan fakta.

b. Pesan politik

Merupakan isi dari informasi yang disampaikan. Dalam Al-Qur'an menganjurkan kepada komunikator agar menyampaikan informasi sesuai dengan sumbernya.

Dalam menerima pesan komunikasi, Islam memerintahkan untuk melakukan ketelitian terhadap informasi yang diterima. Sebagaimana dalam firmanNya surat Al-Hujurat ayat 6: 

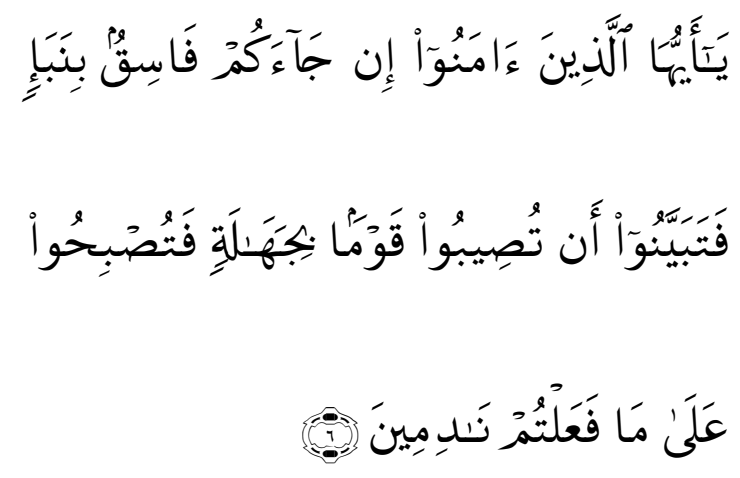

"Hai orang-orang yang beriman, jika datang kepadamu orang fasik membawa suatu berita maka periksalah dengan teliti agar kamu tidak menimpakan suatu musibah kepada suatu kaum tanpa mengetahui keadaannya yang menyebabkan kamu menyesal atas perbuatanmu itu."

c. Media

Sarana (wadah) yang digunakan untuk menyampaikan pesan, misalkan televisi, radio, surat kabar, internet, orasi, dan media lainnya. Setelah ditemukannya media-media baru akibat hasil 
perkembangan teknologi, media mendapatkan peran yang semakin signifikan dalam proses komunikasi. Islam menganjurkan kepada para awak media agar memberikan fakta secara seimbang.

d. Komunikan

Partisipan yang diberikan informasi politik oleh komunikator. Dalam prinsip Islam, komunikan harus bisa menerima informasi sesuai dengan apa yang diterima dari komunikator. Komunikan dilarang membelokkan pemahaman atas apa yang disampaikan komunikator.

e. Feedback

Tanggapan dari komunikan atas informasi politik yang diberikan oleh komunikator. Ketika mendapatkan informasi dari orang yang fasiq, maka sebelum memberikan tanggapan atas informasi yang diterima harus melakukan verifikasi terlebih dahulu sesuai perintah Allah dan RasulNya. 


\section{Komunikasi Transaksional}

Model komunikasi ini merupakan komunikasi dengan proses pengiriman dan penerimaan pesan yang berlangsung secara terus menerus. Komunikasi transaksional bersifat kooperatif, saling berhubungan, saling ketergantungan dan bersama-sama ingin mencapai kesamaan makna. Antara pengirim dan penerima pesan sama-sama bertanggungjawab sehingga efektivitas komunikasi terjadi. Pengalaman masa lalu sangat mempengaruhi seseorang dalam berkomunikasi model transaksional. Misalkan orang yang sedang sharing tentang sebuah penyakit yang dideritanya dihadapan orang yang menderita penyakit yang sama.

Dalam proses komunikasi transaksional secara tidak langsung unsur komunikasi verbal dan non verbal juga termasuk didalamnya. Komunikator dan komunikan saling bertanya, menyela, berkomentar, menggelengkan kepala, tersenyum, tertawa, serta memberi isyarat dengan yang lainnya. 
Prinsip ajaran Islam dalam proses komunikasi transaksional ini, diantaranya adalah saling menghormati, tidak menyela pembicaraan orang lain, selalu menggunakan bahasa yang baik dalam menyampaikan informasi dan menyampaikan yang benar sesuai pengalaman yang pernah dialami.

\section{Komunikasi Verbal dan Non Verbal}

Komunikasi verbal adalah proses komunikasi secara lisan yang menitikberatkan kepada nada suara, bahsa yang digunakan dan kelancaran perkataan yang digunakan.

Sedangkan komunikasi non verbal adalah sebaliknya. Dalam model komunikasi ini, tidak melibatkan suara. Proses komunikasinya melalui penggunaan isyarat, simbol atau pergerakan lainnya dari anggota badan. Dalam dakwah Islam, komunikasi non verbal memberikan kesan makna yang mendalam bagi para jamaahnya. Komunikasi tubuh yang digunakan dalam komunikasi non verbal menjadikan pesan yang 
terkandung dalam proses komunikasi lebih dipahami dan dicerna.

\section{RANGKUMAN}

1. Komunikasi transendental merupakan komunikasi langsung tanpa pembatas antara manusia dengan Tuhan.

2. Komunikasi politik bisa diartikan seluruh proses transmisi, pertukaran, dan pencairan informasi yang dilakukan oleh partisipan dalam kegiatan-kegiatan politik yang terlembaga.

3. Komunikasi transaksional merupakan komunikasi dengan proses pengiriman dan penerimaan pesan yang berlangsung secara terus menerus dan bersifat kooperatif, saling berhubungan, saling ketergantungan serta bersama-sama ingin mencapai kesamaan makna.

4. Komunikasi verbal adalah proses komunikasi secara lisan yang menitikberatkan kepada nada suara, bahsa yang digunakan dan kelancaran perkataan yang digunakan. Sedangkan 
komunikasi non verbal adalah Proses komunikasi melalui penggunaan isyarat, simbol atau pergerakan lainnya dari anggota badan.

\section{EVALUASI}

Untuk memperdalam pemahaman materi ini, diskusikan bersama kelompok mengenai contoh dari model komunikasi transendental, komunikasi politik, komunikasi transaksional serta komunikasi verbal dan non verbal, kemudian demonstrasikan bersama kelompok didepan kelas.

\section{E. DAFTAR PUSTAKA}

Departemen Agama RI. 2004. Al-Qur'an dan

Terjemah. Bandung: . Al-Jumanatul 'Ali.

Iriantara, Yosal. 2014. Komunikasi

Pembelajaran. Bandung: Remaja Rosda Karya.

Rahman, Fazlur. 1996. Tema Pokok AlQur'an. Bandung: Pustaka. 
Ujana, Onong, Effendy. 1999. Ilmu Komunikasi

: Teori dan Praktek. Bandung: Remaja Rosda Karya. 


\section{BAB XI}

\section{PRINSIP DAN AJARAN ISLAM}

\section{DALAM PENERAPAN ILMU ADMINISTRASI \\ NEGARA}

\section{A. PENDAhuluan}

Dalam perspektif Al-Qur'an, negara sebagai institusi kekuasaan diperlukan Islam sebagai instrumen yang efektif untuk merealisasikan ajarannya dalm konteks sejarah. Islam merupakan risalah yang bersifat universal, mengatur hubungan manusia di seluruh aspek kehidupan. Dengan corak pemikirannya yang khas, Islam melahirkan sebuah peradaban yang berbeda dengan peradaban yang lainnya. Islam juga mempunyai aturan kenegaraan yang mampu menyelesaikan masalah interaksi didalam negara maupun interaksi dengan negara lain.

Begitupun juga dalam penerapan ilmu administrasi negara, Islam mempunyai prinsip yang mengacu pada Al-Qur'an dan hadist yang kemudian dijadikan pedoman dalam pengelolaan administrasi negara. Ketentuan-ketentuan dalam 
Al-Quran diturunkan pada para nabi dari waktu ke waktu untuk membimbing umat manusia.

Untuk memperoleh pemahaman yang lebih dalam mengenai materi ini, akan dijelaskan lebih mendalam agar mahasiswa mampu mendeskripsikan bentuk dan sistem pemerintahan dalam perspektif Islam serta mampu memahami sistem administrasi negara dalam Islam.

\section{B. PENYAJIAN MATERI}

\section{Bentuk dan Sistem Pemerintahan dalam} perspektif Islam

Al-Qur'an pada dasarnya adalah kitab yang memuat pesan, petunjuk, dan perintah moral bagi kehidupan manusia di muka bumi. Petunjuk dan perintah ini bersifat universal, abadi dan fungsional. Sebagai intisari wahyu terakhir, AlQur'an bukanlah sebuah wacana hukum atau kitab ilmu politik. Oleh sebab itu, kitab suci ini tidak pernah berbicara secara rinci tentang bentuk masyarakat, dan bentuk pemerintahan yang harus diciptakan umat sepanjang sejarah. Meskipun demikian Al-Qur'an mengisyaratkan dasar-dasar 
fundamental tentang bangunan masyarakat dan pemerintahan yang wajib dijadikan acuan bagi penciptaan sebuah polity (masyarakat dan negara yang teratur) bagi umat.

Seperti yang telah kita ketahui bahwa ada berbagai bentuk dan sistem pemerintahan didunia. Diantaranya adalah sistem kerajaan, imperium, federasi, republik, dan demokrasi. Namun sistem pemerintahan dalam Islam atau yang dikenal dengan khilafah berbeda dengan bentuk pemerintahan di dunia, baik dari segi pemahaman, pemikiran, hukum-hukum yang mengaturnya, konstitusi maupun undang-undang yang diimplementasikan. Secara teknis, khilafah menunjuk kepada institusi pemilihan pengganti nabi sebagai kepala komunitas Islam di Madinah. Dalam literatur klasik, gagasan suksesi mengandung empat unsur pokok yaitu: yang digantikan; pengganti; sasaran suksesi serta hak dan kewajiban yang timbul dari suksesi.

Dalam metode pengangkatan khalifah, sistem pemerintahan Islam menggunakan baiat dari umat. Hal ini berbeda dengan sistem kerajaan yang dalam 
pengangkatan raja menggunakan sistem pewarisan, seorang putra mahkota secara otomatis bisa diangkat menjadi raja. Khalifah juga tidak diberi keistimewaan berada di atas individu umat. Ia dipilih dan dibaiat oleh umat untuk menerapkan hukum-hukum syariah atas mereka. Khalifah terikat dengan hukum-hukum syariah dalam pengambilan kebijakan, keputusan hukum, tindakan serta pengaturan mengenai kemaslahatan umat.

Islam menetapkan kekuasaan, sistem dan peraturan pemerintahan adalah satu untuk semua wilayah. Semua wilayah dianggap sebagai bagian integral dari tubuh negara. Islam menolak berbagai sentimen primordial ('ashbiyât al-jinsiyyah). Islam memberikan berbagai hak pelayanan dan kewajiban-kewajiban kepada non-Muslim yang memiliki kewarganegaraan sesuai dengan hukum syariah. Mereka memiliki hak dan kewajiban yang sama dengan kaum Muslim secara adil. Dengan sistem demikian, Islam tidak menjadikan berbagai wilayah kekuasaan dalam negara sebagai wilayah jajahan, bukan sebagai wilayah yang dieksploitasi.. 
Akan tetapi, Islam menjadikan semua wilayah kekuasaan negara sebagai satu-kesatuan meskipun jaraknya saling berjauhan dan penduduknya berbeda-beda suku.

Sistem pemerintahan Islam adalah sistem kesatuan. Dalam sistem pemerintahan Islam, keuangan seluruh wilayah (propinsi) dianggap sebagai satu-kesatuan dan APBN-nya juga satu, yang dibelanjakan untuk kemaslahatan seluruh rakyat tanpa memandang propinsinya. Adapun mengenai kewenangan untuk melakukan legislasi (menetapkan hukum), pemerintahan Islam menetapkan tidak di tangan rakyat, tetapi ada pada Allah. Tidak seorang pun selain Allah dibenarkan menentukan halal dan haram. Dalam Islam, menjadikan kewenangan untuk membuat hukum berada di tangan manusia merupakan kejahatan besar. Allah SWT berfirman dalam surat atTaubah ayat 31:

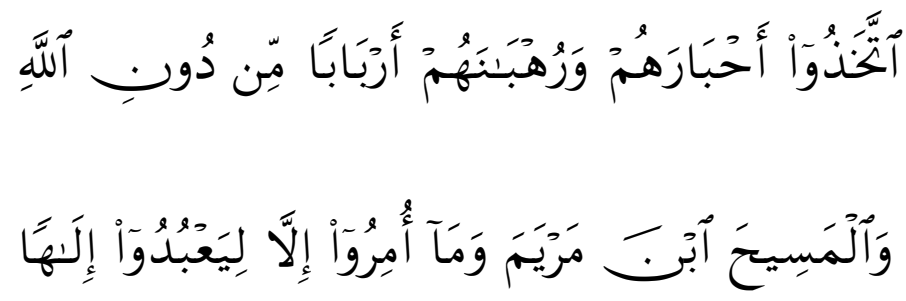




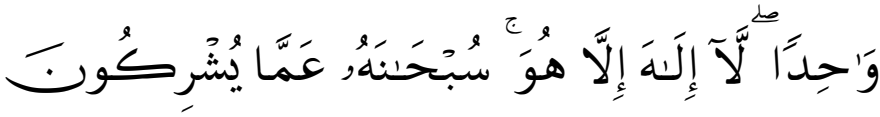

"Mereka telah menjadikan orang-orang alimnya, dan rahib-rahib mereka sebagai tuhan selain Allah. Dan (juga mereka mempertuhankan) alMasih putra Maryam, padahal mereka hanya disuruh menyembah Tuhan yang Maha Esa, tidak ada Tuhan selain Dia. Maha Suci Allah dari apa yang mereka persekutukan”. (QS at-Taubah (9): 31).

Sistem pemerintahan dalam Islam tidak terdapat departemen yang memiliki kekuasaan pemerintahan secara keseluruhan (menurut bentuk demokrasi). Akan tetapi, Khalifah dibaiat oleh umat untuk memerintah mereka menurut Kitabullah dan Sunnah Rasul-Nya. Khalifah berhak menunjuk para mu'âwin (wazîr tafwîdh) untuk membantunya mengemban tanggung jawab kekhilafahan. Mereka adalah para wazîr-dalam makna bahasa-yaitu para pembantu (mu'âwin) 
Khalifah dalam masalah-masalah yang ditentukan oleh Khalifah.

\section{Sistem Administrasi Negara dalam Islam}

Negara adalah instrumen yang diperlukan bagi pelaksanaan ajaran Islam. Dalam ajaran Islam menganjurkan agar masyarakat suatu negara ditegakkan di atas sendi-sendi moral demi mewujudkan keadilan, kebenaran dan persaudaraan dalam kehidupan sosial. Administrasi Negara dalam Islam dibangun berdasarkan falsafah: wa-in kaana dzu "usratin fanadhiratun ila maysarah (jika ada orang yang mempunyai kesulitan, maka hendaknya dilihat bagaimana memudahkannya).

Prinsip Islam dalam mengurusi masalah administrasi dilandasi dengan kaedah sederhana dalam peraturan, cepat dalam pelayanan, serta profesional dalam penanganan. Dalam rangka memenuhi prinsip-prinsip kemudahan ini pula sistem administrasi dalam Islam tidak bersifat sentralistik, yang ditentukan semuanya oleh pusat, sebaliknya bersifat desentralisasi, atau diserahkan 
kepada masing-masing desa, kecamatan, kabupaten/kota, atau propinsi. Dengan demikian kemaslahatan yang akan diselesaikan dapat ditunaikan dengan cepat dan dalam waktu yang singkat, tanpa harus menunggu keputusan dari pusat.

Dengan berpedoman pada Al-Qur'an dan AlHadist, Islam mengatur administrasi negara yang sesuai dengan prinsip-prinsip, yaitu:

- Prinsip Keadilan dan Kemaslahatan; Kebijakan yang diterapkan harus menjamin keadilan dan kemaslahatan bagi semua.

- Prinsip Musyawarah; Sebelum pengambilan keputusan tentang sebuah kebijakan haruslah melalui musyawarah dan mempertimbangkan keseluruhan aspek dan faktor-faktor yang terkait dengan permasalahan tersebut secara komprehensif.

- Prinsip Pertanggungjawaban; Setiap tindakan sekecil apapun akan diminta pertanggungjawabannya dihadapan Allah kelak dan harus bisa dipertanggungjawabkan kepada umat karena menyangkut penggunaan 
kekuasaan dan wewenang serta penggunaan aset yang diamanahkan kepada pengambil kebijakan tersebut.

- Prinsip Hakikat Kepemilikan pada Allah swt; Hakikat kepemilikan bukan pada manusia akan tetapi milik Allah swt, karena alam semesta beserta isinya termasuk manusia didalamnya adalah makhluk (ciptaan) Allah SWT. Manusia hanya diberikan amanah oleh Allah SWT untuk mengelola, memelihara dan memanfaatkan alam semesta ini untuk kemaslahatan seluruh ummat manusia.

- Prinsip Sumber Pengambilan Keputusan; Pengambilan keputusan harus berpedoman pada Al-Qur'an dan Al-Hadist. Apabila permasalahan memerlukan ketegasan hukum yang secara langsung berkait dengan masalah tersebut tetapi belum dapat ditemukan dalam Al-Qur'an maupun as-sunnah maka dipersilahkan untuk melakukan ijtihad.

- Prinsip Maqashid Syariah; Kebijakan publik haruslah mempertimbangkan maqashid syariah. 
- Prinsip Kepemimpinan dan Kepatuhan; Umat haruslah menunjukkan kepatuhan dalam melaksanakan kebijakan yang telah diputuskan dengan musyawarah.

\section{RANGKUMAN}

1. Sistem pemerintahan dalam Islam atau yang dikenal dengan khilafah berbeda dengan bentuk pemerintahan di dunia, baik dari segi pemahaman, pemikiran, hukum-hukum yang mengaturnya, konstitusi maupun undangundang yang diimplementasikan.

2. Prinsip-prinsip Islam dalam mengatur administrasi negara, yaitu: Prinsip Keadilan dan Kemaslahatan; Prinsip Musyawarah; Prinsip Pertanggungjawaban; Prinsip Hakikat Kepemilikan pada Allah swt; Hakikat kepemilikan bukan pada manusia akan tetapi milik Allah swt, Prinsip Sumber Pengambilan Keputusan; Prinsip Maqashid Syariah; dan Prinsip Kepemimpinan dan Kepatuhan.

3. Sistem administrasi dalam Islam tidak bersifat sentralistik, yang ditentukan semuanya oleh 
pusat, sebaliknya bersifat desentralisasi, atau diserahkan kepada masing-masing desa, kecamatan, kabupaten/kota, atau propinsi.

\section{EVALUASI}

Untuk memperdalam pemahaman mengenai bentuk dan sistem pemerintahan, Deskripsikan bentuk dan sistem pemerintahan yang ada di dunia (5 negara) serta analisalah bersama kelompokmu tentang perbandingannya dengan sistem pemerintahan Islam.

\section{E. DAFTAR PUSTAKA}

Departemen Agama RI. 2004. Al-Qur'an dan Terjemah. Bandung: . Al-Jumanatul 'Ali. Maarif, Ahmad Syafi'i. 1996. Islam dan Politik; Teori Belah Bambu. Jakarta: Gema Insani Press.

Shihab, M. Quraish. 1998. Wawasan AlQur'an. Bandung: Mizan. 


\section{BAB XII}

\section{STRATEGI KOMUNIKASI DAKWAH}

\section{A. PENDAhULUAN}

Dalam ajaran agama Islam, dakwah merupakan suatu kewajiban yang dibebankan oleh agama kepada pemeluknya. Dakwah merupakan bagian yang penting bagi umat manusia untuk memperbaiki kualitas spiritual dan akhlak yang telah rapuh dalam diri manusia. Seiring dengan perkembangan zaman, umat menjadi terlalu mengagungkan materi sehingga kekuatan iman mengalami degradasi.

Pada dasarnya dakwah adalah seruan atau ajakan kepada keinsyafan, atau usaha mengubah situasi kepada situasi yang lebih baik dan sempurna, baik terhadap diri sendiri maupun terhadap masyarakat. Dakwah diharapkan bukan hanya sekedar usaha peningkatan pemahaman keagamaan dalam tingkah laku dan pandangan hidup saja, tetapi lebih dari itu, ia diharapkan mampu berperan menuju kepada pelaksanaan ajaran Islam secara lebih menyeluruh dalam 
berbagai aspek kehidupan. Dalam berdakwah harus mempunyai strategi komunikasi yang disesuaikan dengan perkembangan zaman agar komunikan atau sasaran dakwah dapat mengerti dan memahami secara efektif apa yang kita sampaikan.

Untuk memperoleh pemahaman mengenai strategi komunikasi dakwah, maka akan dikaji lebih mendalam agar mahasiswa mampu mendeskripsikan jenis strategi komunikasi dakwah bil hal dan dakwah bil lisan serta mampu menganalisa ayat dan hadist yang relevan dengan strategi komunikasi dakwah.

\section{B. PENYAJIAN MATERI}

\section{Dakwah bil Hal}

Dakwah bil Hal adalah dakwah yang mengedepankan perbuatan nyata. Strategi dakwah ini bisa melalui sikap, perbuatan, contoh, atau keteladanan, misalnya segera mendirikan sholat begitu terdengar adzan, membantu kaum dhuafa atau fakir-miskin, mendanai pembangunan masjid atau membantu kegiatan dakwah, mendamaikan orang yang bermusuhan, bersikap Islami, dll. 
Hal ini dimaksudkan agar penerima dakwah mengikuti jejak dari pendakwah (da'i). Dakwah jenis ini mempunyai pengaruh yang besar pada diri penerima dakwah. Situasi dan kondisi pada masa sekarang sangat menuntut jenis dakwah seperti ini. Situasi dan kondisi yang dimaksud tercermin antara lain dalam:

a. Lemahnya kemampuan kelembagaan dalam mengembangkan swadaya masyarakat.

b. Keterbatasan lapangan kerja dan ketrampilan, khususnya di kalangan miskin pinggiran dan pedesaan.

c. Keterbatasan dana, khususnya di luar kotakota besar, dan keterbatasan tersebut semakin besar dengan adanya pandangan sebagian masyarakat Muslim yang enggan menggunakan kredit perbankan.

Strategi dakwah bil hal dilakukan oleh Rasulullah SAW pada saat pertama kali beliau tiba di kota Madinah, dengan mendirikan Masjid Quba dan mempersatukan kaum Anshor dan kaum Muhajirin dalam ikatan ukhuwah Islamiyah. 
Adapun beberapa hal yang mendasari keefektifan metode dakwah, misalnya saja dalam peristiwa perjanjian Hudaibiyah sebagaimana yang direkontruksikan oleh Rasulullah dan sahabatsahabatnya yaitu:

- Untuk mempengaruhi watak manusia yaitu pengaruh luar atau lingkungan dan pengaruh dari dalam atau keturunan. Dengan demikian aktivitas suatu kelompok sosial akan sangat mempengaruhi individu yang berada disekitarnya.

- Proses imitasi menjadikan kelompok manusia akan menjadi masyarakat yang sebenarnya karena saling meniru, saling mengikuti dan saling mencontoh terhadap aktifitas anggota lainnya.

- Dengan adanya interaksi kelompok, akan terbentuk norma-norma tingkah laku antar anggota kelompok. Norma ini merupakan pedoman untuk mengatur pengalaman dan tingkah laku individu manusia dalam berbagai situasi sosial.

Dakwah bil hal diharapkan dapat memelihara identitas setiap muslim serta 
menunjang kehidupan masyarakat, sehingga pada akhirnya ajaran Islam dapat dirasakan membumi dan cita-cita sosial dapat tercapai.

\section{Dakwah bil lisan}

Dakwah Bil Lisan yaitu metode dakwah yang disampaikan melalui perkataan atau komunikasi lisan (speaking), seperti ceramah, khotbah, atau dialog.

Rasulullah SAW telah melakukan dakwah bil lisan sebagaimana yang terkandung dalam surat Al Ikhlas ayat 1-4, yaitu Islamisasi melalui ucapan. Beliau berkewajiban menjelaskan pokokpokok dan intisari ajaran Islam kepada umatnya (kaum muslimin) melalui dialog dan khutbah yang berisi nasehat dan fatwa. Selain itu beliau juga mengajarkan kepada para sahabatnya, setiap kali turunnya wahyu yang dibawa Malaikat Jibri, yang kemudian dilafalkan dan ditulis di pelepah kurma. Dakwah bil lisan mempunyai beberapa metode, diantaranya mencakup: 


\section{a. Metode Dakwah bil Hikmah}

\section{Kata "hikmah" dalam Al-Quran disebutkan}

sebanyak 20 kali, baik dalam nakirah maupun ma'rifat. Bentuk masdarnya adalah "hukuman" yang diartikan secara makna aslinya yaitu mencegah. Jika dikaitkan dengan hukum berarti mencegah dari kedzaliman, dan jika dikaitkan dengan dakwah maka berarti menghindari hal-hal yang kurang relevan dalam melaksanakan tugas dakwah. Menurut al-Ashma'i adal mula didirikan hukuman (pemerintahan) ialah untuk mencegah manusia dari perbuatan zalim. Menurut Imam alSyaukani, hikmah adalah ucapan-ucapan yang tepat dan benar, atau menurut penafsiran hikmah adalah argumen -argumen yang kuat dan meyakinkan. Adapun metode dakwah yang dilakukan Nabi Muhammad, antara lain melakukan dakwah bil hikmah yaitu memberikan teladan yang terbaik dalam sikap dan perilaku, dengan selalu sopan santun kepada siapapun. Hal ini kemudian diistilahkan dengan akhlaqulkharimah. Beliau mendapat predikat dari langit "uswatun hasanah" yang bermakna teladan 
terbaik dan terpuji. Dengan metode tersebut, puluhan sampai ribuan orang Arab yang tertarik terhadap ajaran Islam, yang kemudian mengucapkan syahadatain (pengakuan terhadap Allah dan Rasul-Nya, Muhammad SAW).

Kelebihan Dakwah Bil Hikmah yaitu :

1. Sifatnya yang sederhana,

2. Tidak memerlukan biaya yang besar,

3. Tidak memerlukan keterampilan yang lebih.

Sedangkan kelemahannya yaitu :

1. Terkadang membuat mad'u jadi jenuh dan bosan,

2. Cenderung mad'u pasif,

3. Tidak kontekstual dengan mad'u.

b. Metode Dakwah Al Mau'idhah AlHasanah

Secara bahasa mau'idzah hasanah terdiri dari dua kata yaitu mau'idzah dan 
hasanah. Kata mau'idzah berasal dari bahasa Arab yaitu wa'adza-ya'idzu-wa'dzan yang berarti nasehat, bimbingan, pendidikan, dan peringatan. Jadi mau'idhah hasanah bisa diartikan sebagai ucapan yang berisi nasihatnasihat yang baik dimana yang bermanfaat bagi orang pendengarnya.

Keunggulan Al Mau'idhah Al-Hasanah yaitu :

1.Pesan-pesan atau materi yang di sampaikan bersifat ringan dan informatif,

2. Tidak mengundang perdebatan,

3. Sifat komunikasinya lebih banyak searah dari dai ke audiens.

Kelemahannya Al Mau'idhah AlHasanah yaitu :

1. Materi tidak akan selamanya mengena dengan kebutuhan mad'u yang bersifat dinamis, 
2. Tidak kontekstual dengan mad'u,

3. Kurangnya penguasaan metodologi dakwah, baik pada ranah dai, materi, maupun mad'u.

c. Metode Dakwah Al-Mujadalah Bi-alLati Hiya Ahsan

Al-Mujadalah merupakan tukar pendapat yang dilakukan oleh dua pihak secara sinergis, yang tidak melahirkan permusuhan dengan tujuan agar lawan menerima pendapat yang diajukan dengan memberikan argumentasi dan bukti yang kuat. Antara satu denagn yang lainnya salaing menghargai dan menghormati pendapat keduanya berpegang pada kebenaran, mengakui kebenaran pihak lain dan ikhlas menerima hukuman kebenaran tersebut.

Keunggulan Al-Mujadalah Bi-al-Lati Hiya Ahsan yaitu :

1.Suasana dakwah akan tampak lebih hidup, 
2. Dapat menghilangkan sifat-sifat individualistik,

3. Menimbulkan sifat-sifat yang positif yaitu berpikir sistematis dan logis, serta materi akan dipahami secara mendalam.

Kelemahannya Al-Mujadalah Bi-al-Lati Hiya Ahsan yaitu :

1. Bila terjadi perbedaan pendapat antara dai dengan penanya atau sasaran dakwah akan memakan waktu yang banyak untuk menyelesaikannya,

2. Pemberi pertanyaaan kadang kurang memperhatikan jika terjadi penyimpangan,

3. Jika jawaban dai kurang tepat pada sasaran pertanyaan, penanya memberi penilaian negatif terhadap dai, misalnya dai kurang pandai atau kurang memahami materi yang di sampaikan. 


\section{Ayat dan Hadist yang relevan}

Ayat-Ayat Al-Quran berikut ini menunjukkan pengertian dakwah sebagai ajakan ke jalan Allah SWT, ajakan kepada kebaikan, serta mencegah kemunkaran.

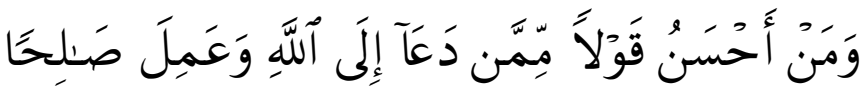

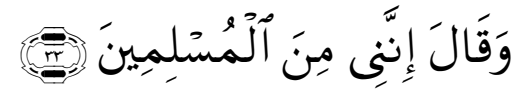

"Siapakah yang lebih baik perkataannya daripada orang yang menyeru menuju Allah, mengerjakan amal yang shalih dan berkata: "Sesungguhnya aku termasuk orang-orang yang berserah diri". [QS. Fushshilat:33].

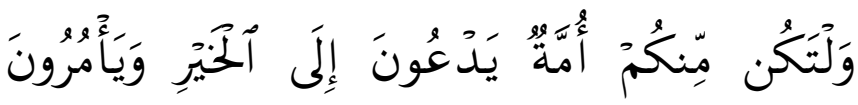

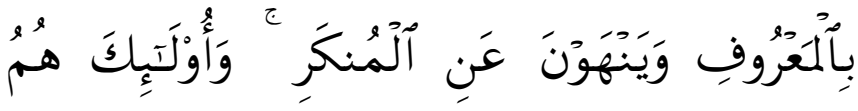

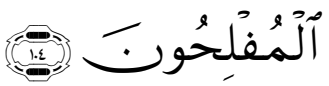

"Dan hendaklah ada dari kamu satu umat yang menyeru kepada kebajikan, menyuruh 
kepada yang ma'ruf dan mencegah dari yang munkar;mereka adalah orang-orang yang beruntung". [QS. Ali Imran:104].

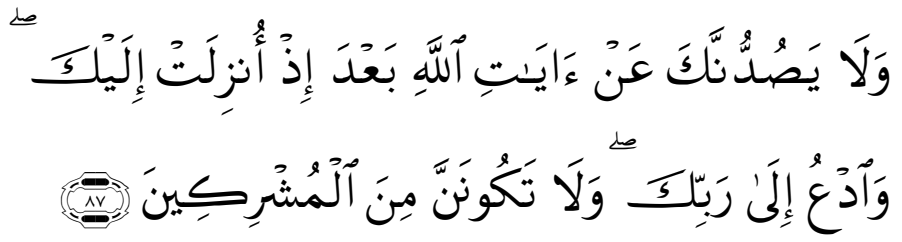

"Dan janganlah sekali-kali mereka dapat menghalangimu dari (menyampaikan) ayat-ayat Allah, sesudah ayat-ayat itu diturunkan kepadamu, dan serulah mereka ke (jalan) Rabb-mu,dan janganlah sekali-kali kamu termasuk orang-orang yang mempersekutukan Rabb".[QS. Al Qashshash:87].

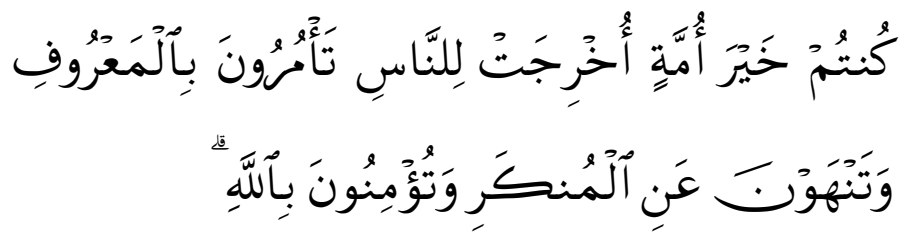

"Kaтu adalah umat yang terbaik yang dilahirkan untuk manusia, menyuruh kepada yang ma'ruf, dan mencegah dari yang munkar, dan beriman kepada Allah". [QS. Ali Imran:110]. 
Dasar-dasar metode dakwah dalam sebuah surat anNahl ayat 125 yang berbunyi:

Le

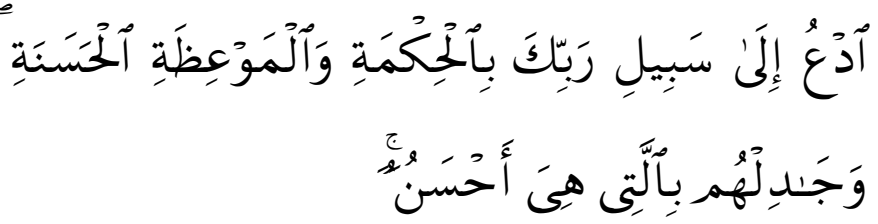

“ serulah (manusia) kepada jalan Tuhan-mu dengan hikmah dan pelajaran yang baik dan bantahlah mereka dengan cara yang baik”

Islam mengajarkan umatnya agar bersikap lemahlembut dalam berdakwah

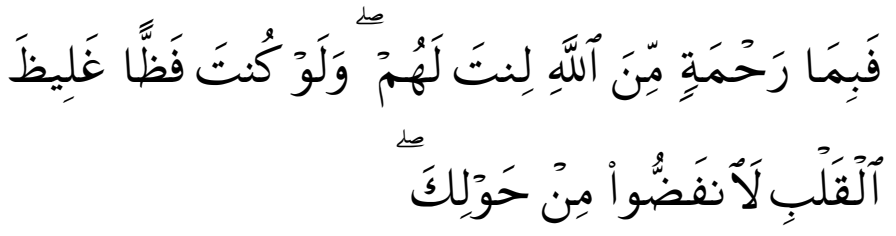

"Maka disebabkan rahmat dari Allahlah kamu berlaku lemah-lembut terhadap mereka, sekiranya kaтu bersikap keras lagi berhati kasar, tentulah mereka menjauhkan diri dari sekelilingmu." (QS. Ali Imran: 159). 


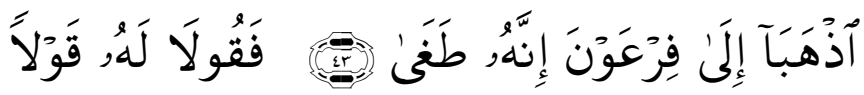

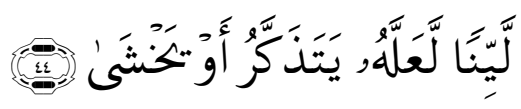

"Pergilah kamu berdua kepada Fir'aun, sesungguhnya dia telah melampaui batas. Maka berbicaralah kamu berdua kepadanya dengan kata-kata yang lemah-lembut, mudah-mudahan ia ingat dan takut." (QS. Thaha:43-44).

Sebagaimana Sabda Rasulullah SAW:

"Sesungguhnya tidaklah kelemahlembutan itu ada pada sesuatu melainkan ia akan memperindahnya dan tidaklah kelemah-lembutan itu dicabut dari sesuatu, melainkan akan memperburuknya." (HR. Muslim).

\section{RANGKUMAN}

1. Dakwah bil Hal adalah dakwah yang mengedepankan perbuatan nyata. Strategi dakwah ini bisa melalui sikap, perbuatan, contoh, atau keteladanan.

2. Dakwah Bil Lisan yaitu metode dakwah yang disampaikan melalui perkataan atau komunikasi 
lisan (speaking), seperti ceramah, khotbah, atau dialog.

3. Metode dakwah bil lisan meliputi: hikmah, mau'idhah hasanah, dan Al-Mujadalah Bi-al-Lati Hiya Ahsan, yang ketiganya mempunyai kelebihan dan kekurangan.

\section{EVALUASI}

Dalam uraian diatas telah dijelaskan mengenai strategi komunikasi dakwah. Demonstrasikan didepan audiens kelas metode dakwah bil lisan dengan materi "Menjadi generasi Rabbani”.

\section{E.DAFTAR PUSTAKA}

Departemen Agama RI. 2004. Al-Qur'an dan Terjemah. Bandung: . Al-Jumanatul 'Ali.

Saputra, Wahidin. 2012. Pengantar Ilmu dakwah, (Jakarta: Raja Gafindo Persada)

Shihab, M. Quraish. 1994. Membumikan AlQur'an. Bandung: Mizan.

Yaqub, Ali Mustafa. 2000. Sejarah dan Metode Dakwah Nabi, Pejaten Barat: Pustaka Firdaus. 


\section{BAB XIII}

\section{ISU-ISU KONTEMPORER DALAM ILMU SOSIAL DAN POLITIK}

\section{A. PENDAhULUAN}

Dalam disiplin fikih, bentukan sosial memainkan peranan yang tidak sedikit. Tuntutan yang muncul dari kepentingan bersama adalah juga prefensi bagi tema-tema fikih yang muncul selanjutnya. Pada zaman modern, saat kepentingan dan kepedulian sudah berubah, agaknya sudah menjadi kemestian jika struktur dan bentuk fikih itu diubah. Bahkan mungkin tema-tema yang sebelumnya tak pernah terpikirkan oleh para ulama klasik bisa dimasukkan dalam kategori fikih, selama disiplin ini dianggap sebagai barometer yuridis setiap tindakan umat Islam.

Tugas para faqih kontemporer adalah mencari setiap akar teologis sebagai pijakan bagi persoalanpersoalan modern. Inilah apa yang dikatakan banyak ulama dan pemikir Muslim modern sebagai upaya pembaharuan (tajdid) Islam. Realisasi proyek tajdid itu dilaksanakan melalui berbagai 
macam medium. Tak terkecuali isu-isu keagamaan kontemporer dalam bidang ilmu sosial dan politik. Instrumen yang paling cepat dalam mengantisipasi isu tersebut adalah dengan menggunakan media komunikasi.

Dalam pembahasan bab ini, mahasiswa diharapkan mampu memahami, menganalisis dan mengantisipasi isu-isu kontemporer dalam yang berkaitan dengan ilmu sosial dan politik, diantaranya mengenai Upah muballigh, Dakwah para Artis, Dakwah Online, Media Literasi dan Masyarakat madani.

\section{B. PENYAJIAN MATERI}

\section{Upah Muballigh}

Menanggapi persoalan "amplop " para muballigh, bagi banyak orang, hal ini sudah merupakan tradisi, dan menganggapnya sebagai hak da'i yang telah menyisihkan waktu dan tenaga. Tetapi ada sebagian yang menganggap itu tidak etis. Dasar mengenai ketidaketisan pendakwah menerima upah adalah: 
QS.Shaad:86, QS.Huud:51, QS.Al-Furqaan:57, QS. Yusuf:104.

Para fuqaha' berbeda pendapat dalam masalah ini. Pertama, kelompok dari mazhab syafi'i dan Maliki yang berpendapat bahwa mengambil imbalan dari pekerjaan adalah boleh. Kedua, dari ulama madzhab Hanafi yang mengharamkan hal ini. Ketiga, pendapat dari Ahmad ibn Hanbal dan Ibn Taimiyah yang membolehkan da'i menerima imbalan dengan syarat menyita tenagadanwaktunya.

Ketua MUI menyatakan bahwa dalam memandang masalah ini harus dilihat secara jernih. Jika pemberian itu dilakukan dengan ikhlas dan tanpa ada perjanjian dimuka adalah boleh. Namun yang tidak boleh jika mematok atau menentukan harga. Sebab, kalau dengan mengharap imbalan, akan mengurangi keikhlasan.

\section{Dakwah Para Artis}

Di media elektronik sering kita jumapai para artis kerap mengisi acara 
keagamaan.Ittihadul Muballighin mulai mempersoalkan masalah ini. Melalui ketuanya, mengungkapkan bahwa mencampuradukkan dakwah dengan hiburan akan membingungkan maksud dakwah tersebut. Meburut Beliau, dakwah dan hiburan mempunyai wilayah yang berbeda.

Pandangan lain mengatakan bahwa Dakwah haruslah mempunyai metode atau strategi. Metode bisa bermacam-macam namun substansinya harus satu. Namun Ironisnya, seringkali artis ikut memberikan fatwah keagamaan tanpa mempunyai penjelasan dan rujukan yang jelas.

MUI dan Ittihadul Muballighin menyangsikan komitmen moral para artis. Setelah memberikan dakwah, mereka masih menerima tawaran berperan di film yang bertentangan dengan materi dakwah yang mereka sampaikan. Jadi dalam masalah ini bisa diambil kesimpulan bahwa seorang artis boleh saja menyampaikan dakwah namun harus 
didahului dengan ilmu dan rujukan yang jelas serta mempunyai komitmen moral yang tegas.

\section{Dakwah Online}

Kemajuan teknologi, khususnya berkembangnya media komunikasi mempengaruhi aktivitas dakwah. Pada masa ini, Dakwah tidak lagi dilakukan sebatas pemberian khutbah di masjid, atau lembaga lainnya. Namun penyebaran informasi dakwah sudah tersebar melalui media teknologi, khusunya internet. Dengan trend digital life, sesungguhnya kemudahan bagi pendakwah semakin terbuka. Dakwah melalui internet dinilai sangat efektif dan potensial karena mampu menembus batas ruang dan waktu yang relatif terjangkau, bisa memilih materi dakwah yang sesuai dengan kebutuhan, penyapaian dakwah lebih variatif, denagn menggunakan fasilitas mailing list dengan mengajak diskusi bisa mengirim pesan moral kepada seluruh anggota, dan bisa memudahkan berinteraksi secara langsung melalui chatting. 
Kesimpulannya, berdakwah secara online diperbolehkan Namun yang perlu diingat bahwa keefektifan media ini sangat tergantung pada umat Islam sendiri. Kecakapan dan keikhlasan dengan kesungguhan mereka dalam mengedepankan persamaan dalam ajakan kepada kebaikan dan menjauhkan dari kebathilan.

\section{Media Literasi}

Literasi media merupakan kemampuan unutk memahami, menganalisis dan mendekonstruksikan pencitraan media. Literasi media juga berfungsi sebagai media dalam pengembangan berdakwah. Media literasi dalam Islam bertujuan untuk memudahkan penyampaian pesan agama supaya sampai kepada masyarakat luas lebih cepat secar bersamaan. Media literasi sangat efektif sebagai alat bantu dalam berdakwah yang tidak hanya terbatas pada penggunaan diagram atau skema dari suatu bahasan tapi juga dalam bentuk narasi dan suara dalam penyampaian 
lisan. Namun yang harus diperhatikan adalah menghindari terjadinya kesalahan informasi.

Kesimpulannya, media literasi bisa digunakan oleh pendakwah sebagai media untuk mengembangkan dakwahnya dengan tujuan agar lebih efektif dan efisien dalam penyampaian dakwah ke masyarakat.

\section{Masyarakat Madani}

Masyarakat madani adalah masyarakat yang beradab, menjunjung tinggi nilai-nilai kemanusiaan, yang maju dalam penguasaan ilmu pengetahuan, dan teknologi. Allah SWT memberikan gambaran dari masyarakat madani dengan firman-Nya dalam Q.S. Saba' ayat 15:

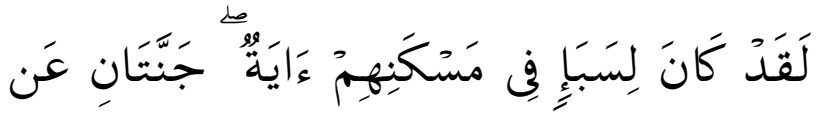

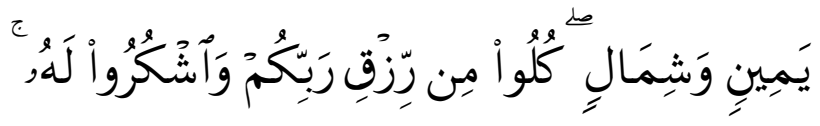

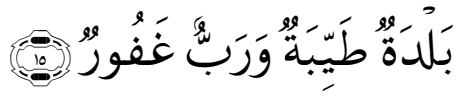


"Sesungguhnya bagi kaum Saba' ada tanda (kekuasaan Tuhan) di tempat kediaman mereka yaitu dua buah kebun di sebelah kanan dan di sebelah kiri. (kepada mereka dikatakan): "Makanlah olehmu dari rezki yang (dianugerahkan) Tuhanmu dan bersyukurlah kamu kepada-Nya. (Negerimu) adalah negeri yang baik dan (Tuhanmu) adalah Tuhan yang Maha Pengampun”.

Ada dua masyarakat madani dalam sejarah yang terdokumentasi sebagai masyarakat madani, yaitu: Masyarakat Saba', yaitu masyarakat di masa Nabi Sulaiman, dan masyarakat Madinah setelah terjadi perjanjian Madinah antara Rasullullah SAW beserta umat Islam dengan penduduk Madinah yang beragama Yahudi dan beragama Watsani dari kaum Aus dan Khazraj. Perjanjian Madinah berisi kesepakatan ketiga unsur masyarakat untuk saling menolong, menciptakan kedamaian dalam kehidupan sosial, menjadikan Al-Qur'an sebagai konstitusi, menjadikan Rasullullah SAW sebagai pemimpin dengan ketaatan penuh terhadap keputusankeputusannya, dan memberikan kebebasan bagi penduduknya untuk memeluk agama serta beribadah 
sesuai dengan ajaran agama yang dianutnya. Ada beberapa karakteristik masyarakat madani, diantaranya:

1. Terintegrasinya individu-individu dan kelompokkelompok ekslusif kedalam masyarakat melalui kontrak sosial dan aliansi sosial.

2. Menyebarnya kekuasaan sehingga kepentingankepentingan yang mendominasi dalam masyarakat dapat dikurangi oleh kekuatan-kekuatan alternatif.

3. Dilengkapinya program-program pembangunan yang didominasi oleh negara dengan programprogram pembangunan yang berbasis masyarakat.

4. Terjembataninya kepentingan-kepentingan individu dan negara karena keanggotaan organisasiorganisasi volunter mampu memberikan masukanmasukan terhadap keputusan-keputusan pemerintah.

5. Tumbuhkembangnya kreatifitas yang pada mulanya terhambat oleh rejim-rejim totaliter. 
6. Meluasnya kesetiaan (loyalty) dan kepercayaan (trust) sehingga individu-individu mengakui keterkaitannya dengan orang lain dan tidak mementingkan diri sendiri.

7. Adanya pembebasan masyarakat melalui kegiatan lembaga-lembaga sosial dengan berbagai ragam perspektif.

8. Bertuhan, artinya bahwa masyarakat tersebut adalah masyarakat yang beragama, yang mengakui adanya Tuhan dan menempatkan hukum Tuhan sebagai landasan yang mengatur kehidupan sosial.

9. Damai, artinya masing-masing elemen masyarakat, baik secara individu maupun secara kelompok menghormati pihak lain secara adil.

10. Tolong menolong tanpa mencampuri urusan internal individu lain yang dapat mengurangi kebebasannya.

11. Toleran, artinya tidak mencampuri urusan pribadi pihak lain yang telah diberikan oleh Allah sebagai 
kebebasan manusia dan tidak merasa terganggu oleh aktivitas pihak lain yang berbeda tersebut.

12. Keseimbangan antara hak dan kewajiban sosial.

13. Berperadaban tinggi, artinya bahwa masyarakat tersebut memiliki kecintaan terhadap ilmu pengetahuan dan memanfaatkan kemajuan ilmu pengetahuan untuk umat manusia.

14. Berakhlak mulia.

Dari beberapa ciri tersebut, kiranya dapat dikatakan bahwa masyarakat madani adalah sebuah masyarakat demokratis dimana para anggotanya menyadari akan hak-hak dan kewajibannya dalam menyuarakan pendapat dan mewujudkan kepentingankepentingannya; dimana pemerintahannya memberikan peluang yang seluas-luasnya bagi kreatifitas warga negara untuk mewujudkan programprogram pembangunan di wilayahnya. Ada tujuh prasyarat masyarakat madani, yaitu:

1.Terpenuhinya kebutuhan dasar individu, keluarga, dan kelompok dalam masyarakat. 
2. Berkembangnya modal manusia (human capital) dan modal sosial (socail capital) yang kondusif bagi terbentuknya kemampuan melaksanakan tugas-tugas kehidupan dan terjalinya kepercayaan dan relasi sosial antar kelompok.

3. Tidak adanya diskriminasi dalam berbagai bidang pembangunan; dengan kata lain terbukanya akses terhadap berbagai pelayanan sosial.

4. Adanya hak, kemampuan dan kesempatan bagi masyarakat dan lembaga-lembaga swadayauntuk terlibat dalam berbagai forum dimana isu-isu kepentingan bersama dan kebijakan publik dapat dikembangkan.

5. Adanya kohesifitas antar kelompok dalam masyarakat serta tumbuhnya sikap saling menghargai perbedaan antar budaya dan kepercayaan.

6. Terselenggaranya sistem pemerintahan yang memungkinkan lembaga-lembaga ekonomi, hukum, dan sosial berjalan secara produktif dan berkeadilan sosial. 
7. Adanya jaminan, kepastian dan kepercayaan antara jaringan-jaringan kemasyarakatan yang memungkinkan terjalinnya hubungan dan komunikasi antar mereka secara teratur, terbuka dan terpercaya.

\section{RANGKUMAN}

1. Upah Muballigh boleh diterima, jika pemberian itu dilakukan dengan ikhlas dan tanpa ada perjanjian dimuka.

2. Seorang artis boleh saja menyampaikan dakwah namun harus didahului dengan ilmu dan rujukan yang jelas serta mempunyai komitmen moral yang tegas.

3. Berdakwah secara online diperbolehkan namun harus disertai dengan. kecakapan dan keikhlasan serta kesungguhan pendakwah dalam mengedepankan persamaan dalam ajakan kepada kebaikan dan menjauhkan dari kebathilan.

4. Media literasi bisa digunakan oleh pendakwah sebagai media untuk mengembangkan dakwahnya dengan tujuan agar lebih efektif dan efisien . 
5. Masyarakat madani adalah masyarakat yang beradab, menjunjung tinggi nilai-nilai kemanusiaan, yang maju dalam penguasaan ilmu pengetahuan, dan teknologi.

\section{EVALUASI}

Diskusikan bersama kelompok mengenai isu-isu kontemporer yang sedang beredar pada saat ini dan analisislah!

\section{E. DAFTAR PUSTAKA}

Assyaukanie, Luthfi. 1998. Politik, Ham, dan IsuIsu Teknologi dalam Fikih Kontemporer. Bandung: Pustaka Hidayah.

Departemen Agama RI. 2004. Al-Qur'an dan Terjemah. Bandung: . Al-Jumanatul 'Ali. Rahman, Fazlur. 1996. Tema Pokok AlQur'an. Bandung: Pustaka. 


\section{BIODATA PENULIS}

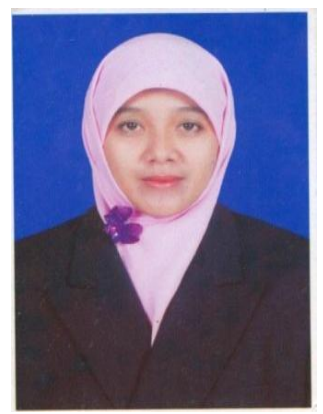

Anita Puji Astutik, lahir di Sidoarjo pada tanggal 21 Januari 1980. Dosen tetap Universitas Muhammadiyah Sidoarjo yang mengampu mata kuliah Al-Islam dan Kemuhamadiyahan dan mata kuliah Pendidikan Agama Islam ini memperoleh gelar kesarjanaan dari Fakultas Tarbiyah jurusan Pendidikan Agama Islam Institut Agama Islam Negeri Sunan Ampel Surabaya dengan predikat Cumlaude (2001). Aktifitas sosial keagamaan di organisasi Aisiyah dan partisipasi di tengah masyarakat serta menjadi praktisi di dunia pendidikan tidak melupakan dahaganya dengan dunia akademis. kegemarannya membaca dan berdiskusi mengantarkannya kembali ke bangku perkuliahan Pasca Sarjana Universitas Muhammadiyah Sidoarjo. Gelar M.PDI dari Universitas Muhammadiyah Sidoarjo diperoleh dengan predikat Cumlaude pada tahun 2013. Untuk memperdalam keilmuannya tentang Islam, Konsentrasi kajian Islam Kontemporer diambilnya dalam studi S3 di Universitas Islam Negeri Sunan Ampel Surabaya. 
